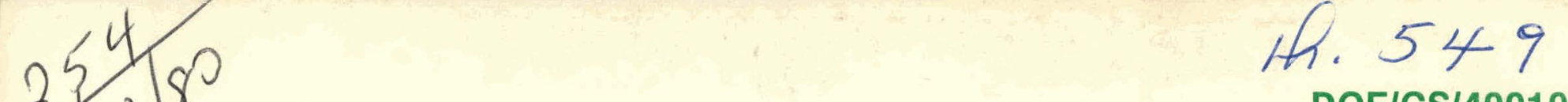

Final Report

\title{
HIGH EFFECTIVENESS RECUPERATORS FOR FLUE GAS APPLICATIONS
}

September 18, 1979

Work Performed Under Contract

No. DE-AC07-77CS40010

(Formerly Contract No. EC-77-C-07-1642)

\section{U. S. DEPARTMENT OF ENERGY} IDAHO OPERATIONS OFFICE AIRESEARCH MANUFACTURING COMPANY OF CALIFORNIA 


\section{DISCLAIMER}

This report was prepared as an account of work sponsored by an agency of the United States Government. Neither the United States Government nor any agency Thereof, nor any of their employees, makes any warranty, express or implied, or assumes any legal liability or responsibility for the accuracy, completeness, or usefulness of any information, apparatus, product, or process disclosed, or represents that its use would not infringe privately owned rights. Reference herein to any specific commercial product, process, or service by trade name, trademark, manufacturer, or otherwise does not necessarily constitute or imply its endorsement, recommendation, or favoring by the United States Government or any agency thereof. The views and opinions of authors expressed herein do not necessarily state or reflect those of the United States Government or any agency thereof. 


\section{DISCLAIMER}

Portions of this document may be illegible in electronic image products. Images are produced from the best available original document. 
Printed in the United States of America Available from

National Technical Information Service

U.S. Department of Commerce

5285 Port Royal Road

Springfield, Virginia 22161

NTIS Price Codes: Printed Copy A05

Microfiche A01

\section{NOTICE}

This report was prepared as an account of work sponsored by an agency of the United States Government. Neither the United States nor any agency thereof, nor any of their employees, makes any warranty, expressed or implied, or assumes any legal liability or responsibility for any third party's use or the results of such use of any information, apparatus, product or process disclosed in this report, or represents that its use by such third party would not infringe privately owned rights. 


\section{HIGH EFFECTIVENESS RECUPERATORS FOR FLUE GAS APPLICATIONS}

79-15749,

September 18,1979

Prepared by

M. Coombs, S.T. Jakubowski and R.K. Smith

Approved by

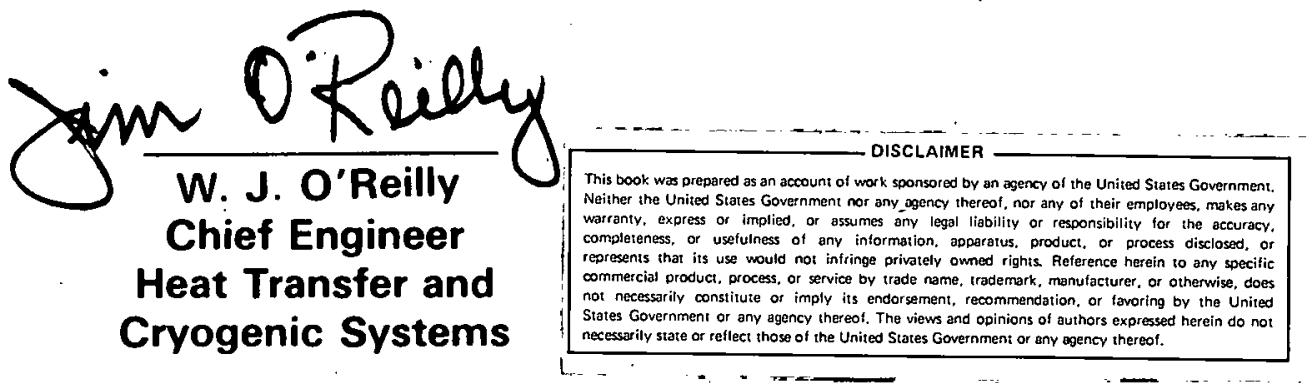

Prepared for

Department of Energy

Waste Energy Utilization and Cogeneration Branch

Office of Industrial Programs

Washington, D.C. 20585

Contract No. DE-AC07-77CS40010

(formerly Contract No. EC-77-C-07-1642)

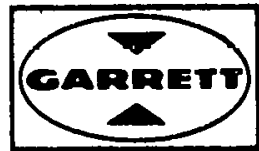

AIRESEARCH MANUFACTURING COMPANY

OF CALIFORNIA 


\section{CONTENTS}

Section

INTRODUCTION AND SUMMARY

Page

$1-1$

introduction $1-1$

Summary

$1-4$

Prospects for Commercial Application

$1-10$

2 SYSTEM DETAIL AND DESIGN RATIONALE

$2-1$

3 FABRICATION AND INSTALLATION

$3-1$

Recuperator Description

$3-1$

Furnace Detail

$3-4$

4

DEMONSTRATION PROGRAM

$4-1$

Test Rationale

4-1

Instrumentation

4-1

Sample Unrecuperated Daily Furnace Loading

4-2 and Fuel Consumption Profile

Cumulative Load/Fuel-Consumption Profiles

4-2

Daily Load/Energy-Consumption Data Correlation

$4-9$

Energy Savings through Recuperation

$4-14$

Cost Savings and Project Payback teriod

$4-20$

Recuperator Performance

$4-20$

Required Maintenance; Condition of Furnace and

4-26

Components After One Year of Recuperated

Operation

5 CONCLUSIONS AND RECOMMENDATIONS

$5-1$

Appendix

A SYSTEM THERMAL ANALYSIS A-I

B METHOD OF RECUPERATOR TEST DATA ANALYSIS B-

C APPROXIMATION OF RECUPERATED FUEL SAVINGS W WITH C-I

FLUE GAS AND AIR PREHEAT TEMPERATURES

D REFERENCES D-I 


\section{ILLUSTRATIONS}

\begin{tabular}{|c|c|c|}
\hline Figure & & Page \\
\hline $1-1$ & $\begin{array}{l}\text { Fuel Savings Using Recuperation for Combustion } \\
\text { Air Preheat }\end{array}$ & $1-2$ \\
\hline $1-2$ & $\begin{array}{l}\text { Relationship of Surveyed Industries to Total } \\
\text { U.S. Energy Consumption, } 1974\end{array}$ & $1-5$ \\
\hline $1-3$ & $\begin{array}{l}\text { Industrial Sector Gas and } 0 \text { il Consumption and } \\
\text { Potential Fuel Savings Using Flue Gas Recuperation }\end{array}$ & $1-5$ \\
\hline $1-4$ & Simplified System Schematic & $1-7$ \\
\hline $1-5$ & McGowan Furnace Recuperator Core & $1-7$ \\
\hline $1-6$ & Completed Recuperator Core & $1-8$ \\
\hline $1-7$ & $\begin{array}{l}\text { McGowan Aluminum Remelt Furnace After Modification } \\
\text { for Recuperation }\end{array}$ & $1-8$ \\
\hline $1-8$ & $\begin{array}{l}\text { Modified McGowan Furnace; View From Northwest } \\
\text { Showing Combustion Air Blower (Bottom), Blower/ } \\
\text { Recuperator Air Transition Duct With Control } \\
\text { Damper and Flowmeter Sections, Recuperator, } \\
\text { Recuperator/Burner Air Transition Ducts, and } \\
\text { Burners }\end{array}$ & $1-9$ \\
\hline $2-1$ & $\begin{array}{l}\text { Recuperated Furnace Combustion System With } \\
\text { Optional Gas/0il Fuel Selection }\end{array}$ & $2-2$ \\
\hline $3-1$ & McGowan Furnace Recuperator Core Dimensions & $3-2$ \\
\hline $3-2$ & Completed Recuperator Core & $3-2$ \\
\hline $3-3$ & Recuperator Installation & $3-3$ \\
\hline $3-4$ & $\begin{array}{l}\text { McGowan Aluminum Remelt Furnace After Modification } \\
\text { for Recuperation }\end{array}$ & $3-5$ \\
\hline $3-5$ & $\begin{array}{l}\text { Overview of McGowan Furnace Before Modification } \\
\text { for Recuperation }\end{array}$ & $3-6$ \\
\hline $3-6$ & Unrecuperated Combustion Air and Gas Supply & $3-6$ \\
\hline $3-7$ & McGowan Rear Door (Before Furnace Modification) & $3-7$ \\
\hline $3-8$ & $\begin{array}{l}\text { McGowan North Side Clean Out Door (Before Furnace } \\
\text { Modification) }\end{array}$ & $3-7$ \\
\hline
\end{tabular}


3-9 McGowan Flue and Stack Before Modification 3-8

3-10 McGowan Aluminum Remelt Furnace Modification for 3-9 Recuperation

3-11 Furnace During Disassembly 3-10

3-12 Combustion Air Supply Pipe, Recuperator Behind 3-10

3-13 View from South During Furnace Modification 3-11

3-14 Insulation of Combustion Air Piping 3-11

3-15 Overview of Completed Installation from Northwest 3-12

3-16 View of Recuperator from North 3-12

3-17 Burners and Hot Air Ducting 3-13

3-18 Pressure and Temperature Probes 3-13

3-19 Roof Mounted Exhaust Fan 3-15

4-1 Mc.Gowan Aluminum Remelt Furnace Recuperator 4-4

System Instrumentation

4-2 Instrumentation Panel 4-5

4-3 McGowan Furance Load/Fuel-Consumption Profile; 4-6

Random 24-Hour Period Prior to Recuperation

4-4 McGowan Furnace Cumulative Load and Fuel 4-7

Consumption Profiles

4-5 Effect of Daily Melting Rate on McGowan Furnace 4-12 Specific Energy Consumption: Recuperated vs Unrecuperated Furnace Operation

4-6 Unrecuperated Specific Energy Consumption of 4-13 McGowan Furnace

4-7 Effect of Daily. Melting Rate on Recuperated 4-15 Fuel Savings

4-8 Effect of Daily Melting Rate on Energy Consumption, 4-22 Savings, and Payback Period 
4-9 Typical Test Data 4-24

4-10 Effect of Time on Recuperator Performance 4-25

4-11. McGowan Furnace After One Year of Recuperated 4-27 Operation; View from Northeast Showing Loading Door (Left), Burner, Recuperator/Burner Air Transition Duct, and Instrument Subpanel (Right)

4-12 McGowan Furnace After One Year of Recuperated 4-28 Operation; View from Southwest Showing Rear Door, Recuperator, and Exhaust Dilution Air Duct

4-13 McGowan Furnace After One Year of Recuperated Operation; View from Northwest Showing Combustion Air Blower (Bottom), Blower/Recuperator Air Transition Duct with Control Damper and Flowmeter Sections, Recuperator, Recuperator/Burner Air Transition Duct, and Burners

A-1 McGowan Furnace Heat Distribution

A-2 Effect of Excess Air on Theoretical and Estimated Actual Flame Temperatures $\left(T_{1 A}=100^{\circ} \mathrm{F}\right)$

A-3 Effect of Excess Air on Theoretical and Estimated Actual $\mathrm{Flame}$ Temperatures $\left(\mathrm{T}_{1 \mathrm{~A}}=1332^{\circ} \mathrm{F}\right)$

A-4. Effect of Air Flow and Fuel Flow on Flame Temperature for 2,709,368 BTU/Hr Furnace Heat Addition 


\section{TABLES}

Table

Page

2-1 McGowan Furnace Recuperator Performance Requirements 2-3

4-1 Thermocouple Detail 4-1

4-2 Recuperator Instrumentation and Transducer Detail 4-3

4-3 McGowan Furnace Load and Fuel Consumption Data 4-8

4-4 Effect of Calendar Time on Specific Energy Consump- 4-11 tion Correlation and Determination Coefficients:

Recuperated Opeation

4-5 McGowan Furnace Load and Fuel Consumption Summary 4-14

4-6 Typical Recuperated Furnace High-Fire Data Near Top 4-19 of Heating Cycle (Run 5-3, 8-1-78)

4-7 McGowan Furnace Recuperator Cost Summary 4-21

A-1 McGowan Furnace Analysis Summary A-5 
SECTION 1

INTRODUCTION AND SUMMARY

\section{INTRODUCTION}

This report summarizes the results of an energy recovery demonstration program conducted under the U.S. Department of Energy cost sharing contract EC-77-C-07-1642, "High Effectiveness Recuperation for Flue Gas Applications".

\section{Background}

Energy wasted by the United States industrial community in typical manufacturing processes has been estimated at up to 90 percent of the energy in the fuel consumed. In some instances, additional energy is consumed to reduce high process discharge temperatures prior to exhaust. Much of this wasted energy can be recycled for use in the process, for plant heating, or for other applications.

Natural gas production dropped over 7 percent in 1975; proven reserves of natural gas also declined, and are currently at the lowest level since 1956. Industrial demand is for 11 trillion cubic feet annually, with only 8 trillion cubic feet available. The growing demand for natural gas and the simultaneous reduction in supply generate increased interest in the use of heat recovery devices to conserve energy.

Significant energy savings can be achieved by the introduction of heat exchangers which recover a portion of the waste heat in industrial process effluents. Two types are currently available for flue gas heat recovery: tubular recuperators and rotary regenerators. Size and cost constraints limit tubular recuperators to about 65 percent energy recovery effectiveness. Rotary regenerators can achieve 80 percent effectiveness but have limited application due to high cost, limited reliability, and excessive maintenance requirements.

The flue gas energy loss is reduced by utilizing the hot gas to preheat combustion air. The exhaust to the atmosphere is then reduced in both temperature and flow rate and less fuel is required to achieve the product heating. The energy recovered and the corresponding fuel savings are proportional to the thermodynamic effectiveness of the recuperative heat exchanger. This relationship is illustrated in Figure $1-1$ which shows the fuel savings as a function of flue gas temperature and the effectiveness of the recuperator. For example, the installation of a 40-percent-effective recuperator in a $1600^{\circ} \mathrm{F}$ exhaust gas stack will result in a fuel savings of slightly less than 20 percent. By contrast, an 85-percent-effective recuperator in the same stack will save about 34 percent of the unrecuperated fuel consumption. These figures are simplistic in that they neglect recuperator-to-burner transition duct heat losses but, nevertheless, they show the importance of recuperator effectiveness in energy conservation. 


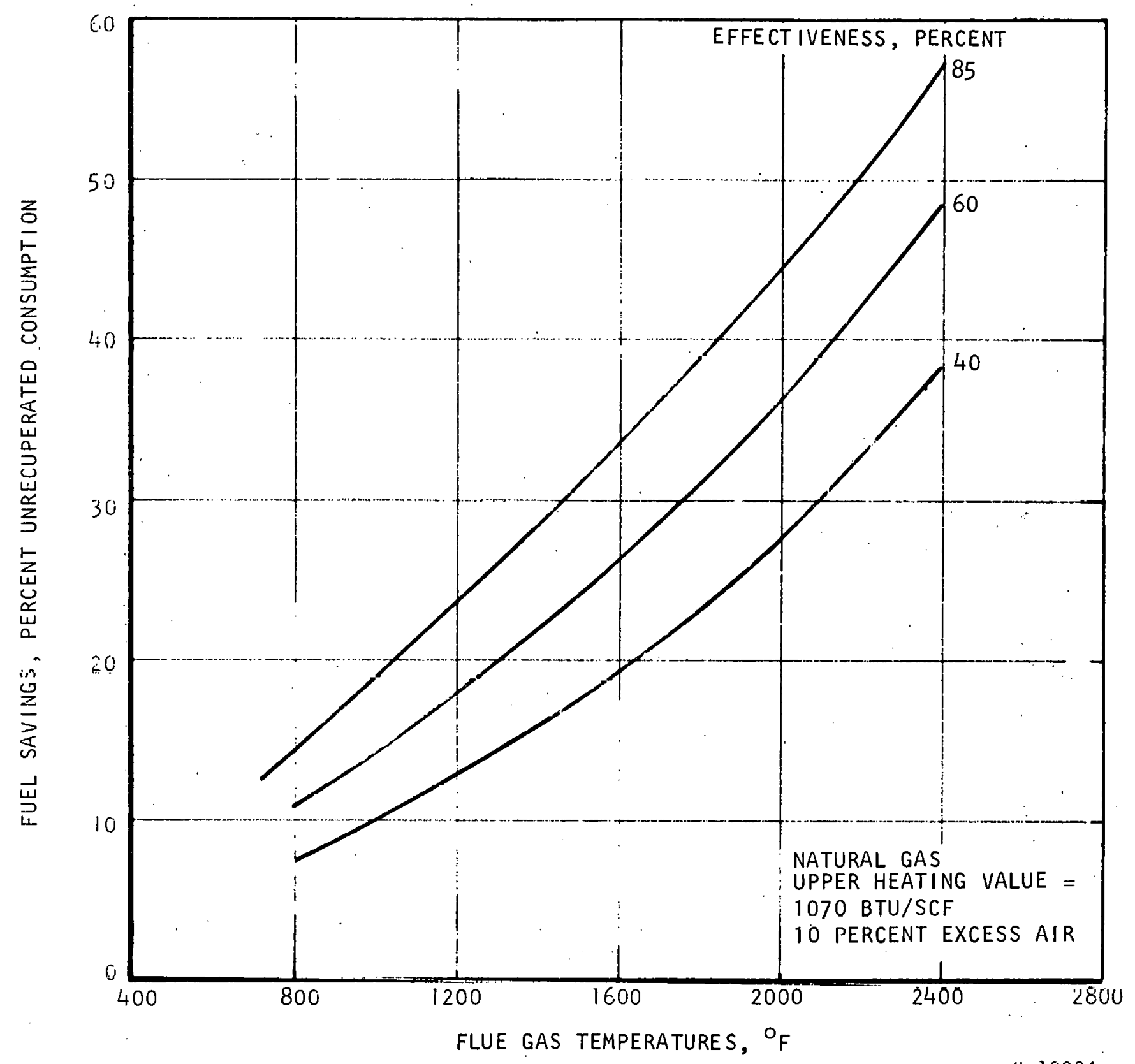

$s-19024$

Figure 1-1. Fuel Savings Using Recuperation for Combustion Air Preheat 
The plate-fin heat exchanger geometry, in which alternate layers of corrugated. sheet stock are separated by plates, achieves a compactness and packaging flexibility that is impractical to implement with contemporary recuperator concepts. This geometry has heretofore been utilized primarily in high technology applications; however, recent developments in fabrication techniques and materials technology have lowered the cost and allowed fabrication of largescale units.

While there was no doubt that plate-fin heat exchangers could achieve high performance within a minimum envelope, there was no experience relative to the ability of this construction to tolerate the hostile conditions imposed by the furnace exhaust. To obtain this experience, AiResearch entered into a costsharing contract with the Department of Energy to demonstrate the performance and operating characteristics of a high effectiveness plate-fin recuperator operating in a typical industrial furnace application. The specific objective was to evaluate the plate-fin construction in a flue-gas environment with respect to structural adequacy, leakage, chemical and erosive attack, susceptibility to fouling and plugging, recuperator/burner compatibiltiy, and maintenance requirements.

\section{Task Descriptions}

... A six-task work statement was formulated to accomplish these objectives. This is summarized below:

- TASK 1 - INDUSTRY SURVEY

a. Southern California industry survey to identify applications with large potential for flue gas waste heat. recovery

b. Analysis and evaluation of data

c. Extrapolation of California energy use data to national scope

d. Issue of summary report. (Reference 1)

- TASK II - RECUPERATOR DESIGN

a. Plant survey and selection of demonstration furnace

b. Unrecuperated furnace monitor and data analysis to establish a baseline evaluation standard

c. System analysis and design

d. Recuperator mounting platform design

- TASK 111 - hARDWARE PROCUREMENT AND FABRICATION 

a. Installation of mounting platform
b. Installation of recuperator
c. Installation of combustion air blower and roof-mounted exhaust fan
d. Installation of high-temperature dual/fuel burners
e. Installation of blower/recuperator air supply duct and recuperator/burner transition duct
f. Installation of controls and instrumentation
a. System shakedown operation, including flow and control adjustments

- task V - RECUPERATOR demONSTRATion

Recording and revielv of 127 data sets; thermodynamic analysis of 50 typical data sets

- TASK VI - PROGRAM MANAGEMENT AND REPORTING

Issue of monthly letter progress reports and six formal progress reports.

SUMMARY

Survey

The objective of the Task I survey was to determine the potential savings that could be realized with the application of high effectiveness flue-gas recuperators to pre-heat combustion air. The manufacturing classifications covered by the survey and literature studies were glass, cement, clay and pottery, steel and primary metals, foundries, forges, and selected metalworking industries. These industries represent about 28 percent of the energy consumption of the industrial sector.

The total energy consumption of the U.S. in 1974 amounted to 73 quads ( 1 quad $=1015$ BTU's) of which the industrial sector accounted for 23 quads. of the 23 quads, 8.28 quads represents the total industrial consumption of natural gas and oil. Of the 8.28 quads, the industries surveyed represents 2.33 quads. Using 85 percent effectiveness flue gas recuperators for combustion air preheat, the potential U.S fuel savings is estimated to be 0.35 quad per year. This represents 15 percent of the total natural gas and oil consumed by the industries surveyed and an annual cost savings of about one billion dollars per year at current fuel prices. These projections are illustrated graphically in Figures 1-2 and 1-3 which are taken from Reference 1 , which was issued in October 1977. 


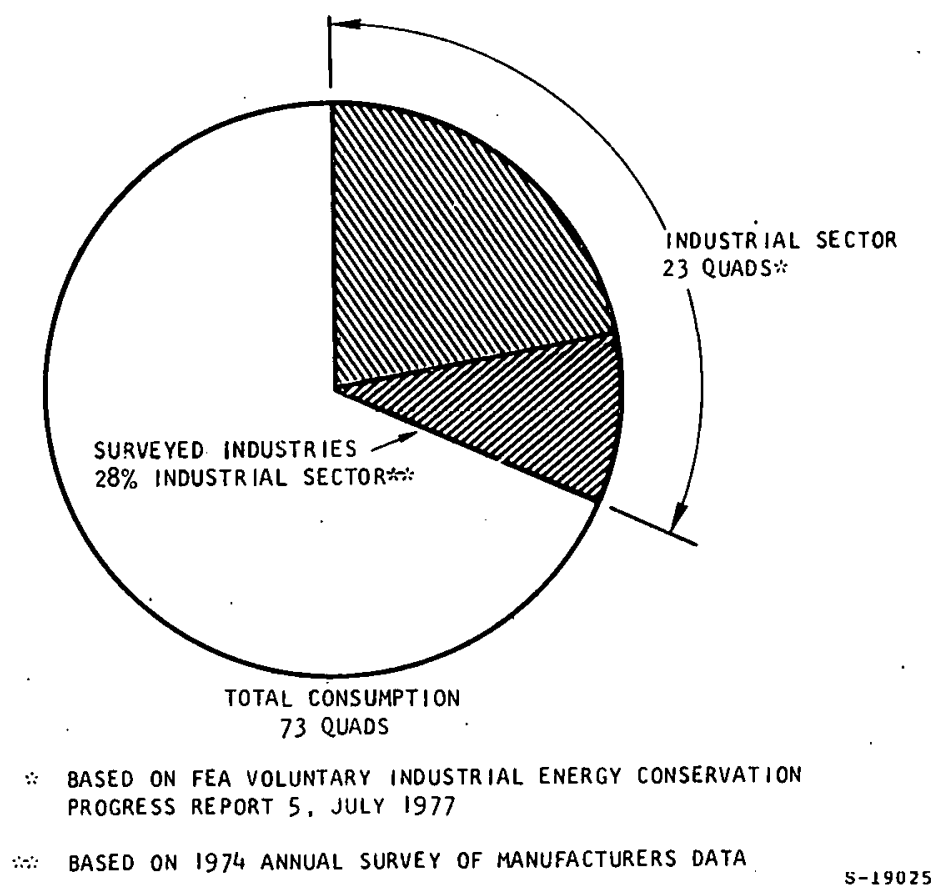

Figure 1-2. Relationship of Surveyed Industries to Total U.S. Energy Consumption, 1974

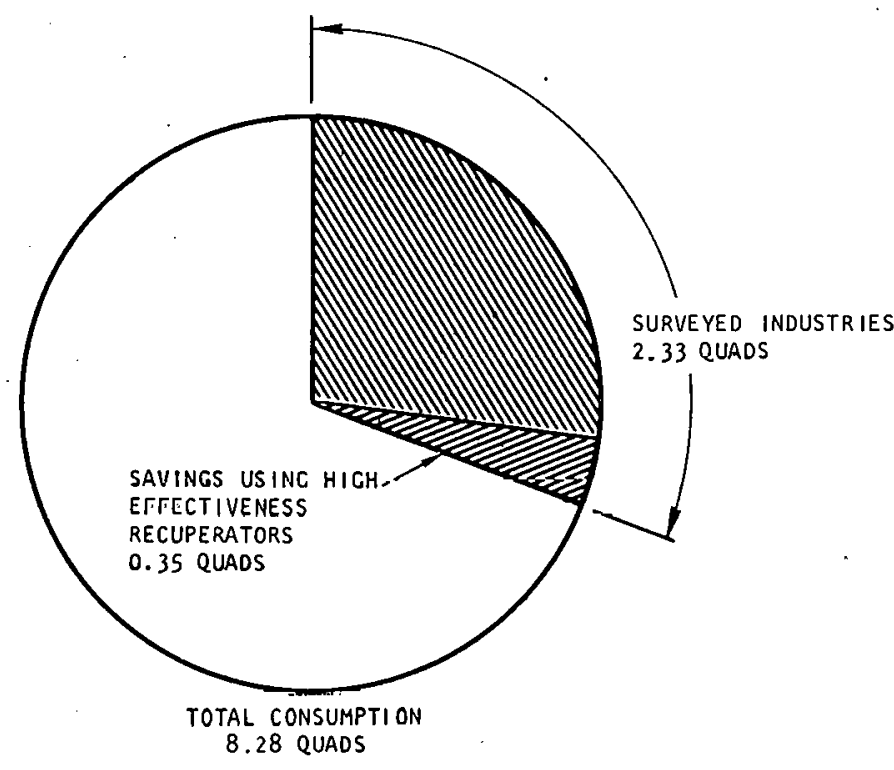

BASEO ON 1974 ANNUAL SURVEY OF MANUFACTURERS DATA

Figure 1-3. Industrial Sector Gas and 0 il Consumption and Potential Fuel Savings Using Flue Gas Recuperation 


\section{Demonstration Program}

\section{System Description}

A McGowan reverberatory aluminum remelt furnace at the AiResearch Casting Company was selected for the demonstration of the flue gas recuperator. This furnace has a nominal rated burner capacity of $3.2 \mathrm{million} B T U / \mathrm{hr}$ and a melting capacity of 1000 pounds of aluminum per hour. It is used to supply holding pots from which about 30 percent of the foundry's production is presently poured. Both pig aluminum and gates and risers are melted in the furnace.

In addition to the heat exchanger, the recuperated system required (1) new burners capable of utilizing $1350^{\circ} \mathrm{F}$ air, (2) a new blower of higher capacity, (3) an induced-draft fan, (4) an exhaust gas/air dilution system, (5) relocation of the burners, and (6) general rework of the combustion plumbing and contrnl system. A simplified schematic of the plumbing for the recuperated furnace is shown in Figure $1-4$.

The system was designed to provide $1350^{\circ} \mathrm{F}$ preheated air to the two high temperature burners. Flue gas temperature into the recuperator was limited to $1550^{\circ} \mathrm{F}$ by means of a cold air bypass system that supplied dilution air to the flue gas.

The stainless-steel recuperator (Figure 1-5) is designed to an overall counterflow configuration that is optimum in maximizing the mean temperature difference between the flow streams and also in limiting thermal stresses in the core. Lateral distribution and collection of the air is accomplished with mitered triangular fin sections that are oriented perpendicular to the counterflow fins. Figure 1-6 shows the brazed core assembly before the addition of ducts and insulation.

The modified furnace is shown schematically in Figure $1-7$. Referring to Figure 1-7, a damper in the dilution air duct is actuated by a slgnal from a thermocouple in the exhaust stream. When the exhaust temperaturc exceeds $1550^{\circ} \mathrm{F}$, the damper is opened to admit secondary cooling air. The combustion airflow is essentially unaffected by damper fluctuations because the blower has a flat performance characteristic that maintains a near-constant pressure differential across the recuperator. A photo of the completed installation is shown in Figure 1-8.

The installation was instrumented to record air flow, fuel flow, and recuperator flue gas and air temperatures and pressure drops. 


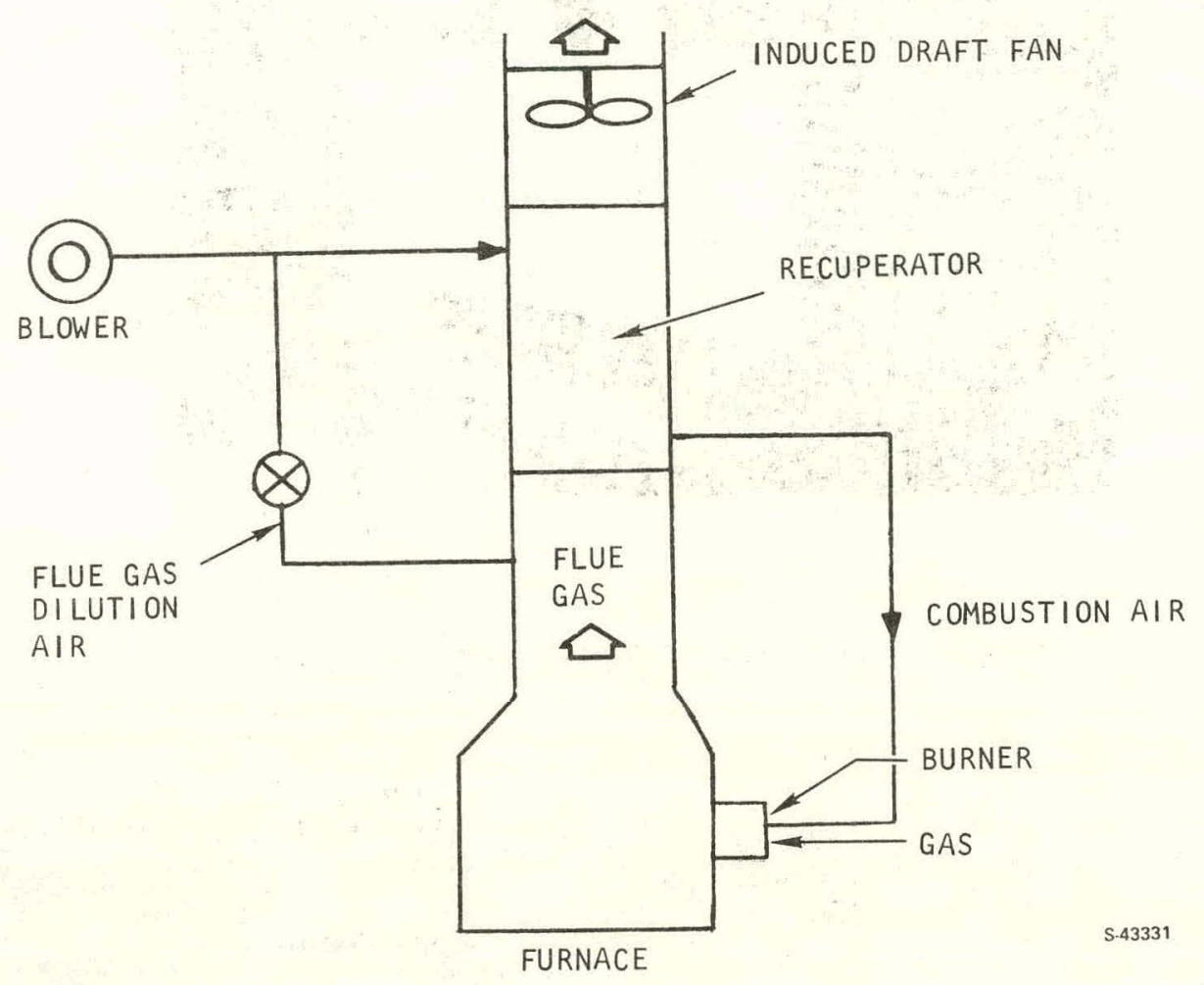

Figure 1-4. Simplified System Schematic

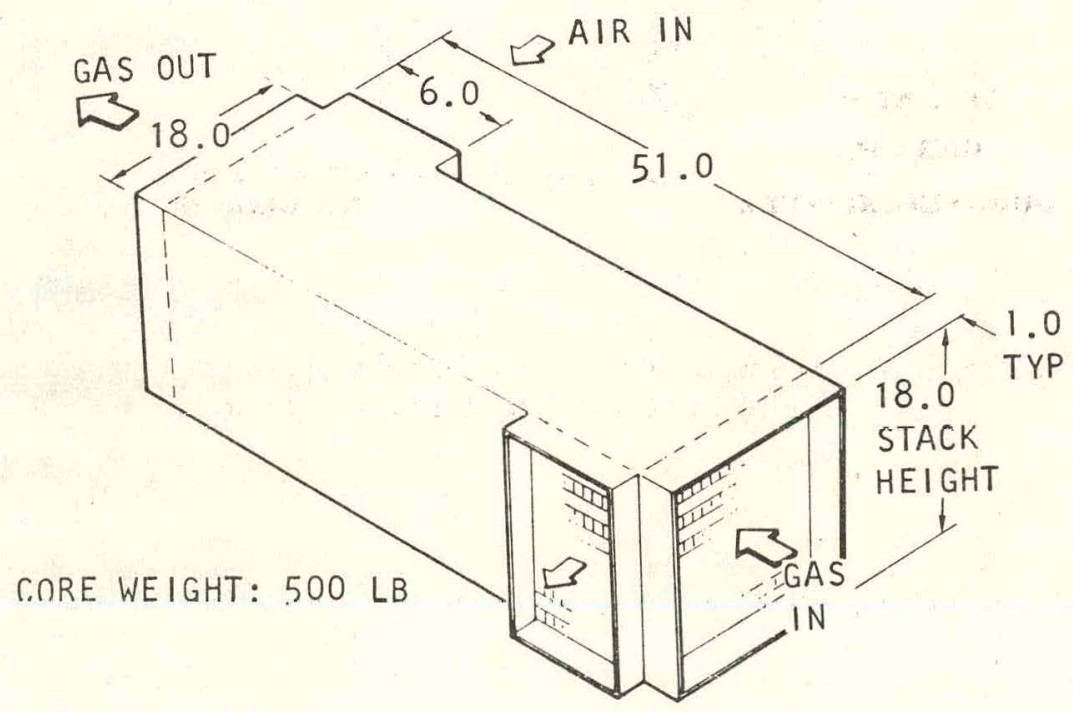

Figure 1-5. McGowan Furnace Recuperator Core 


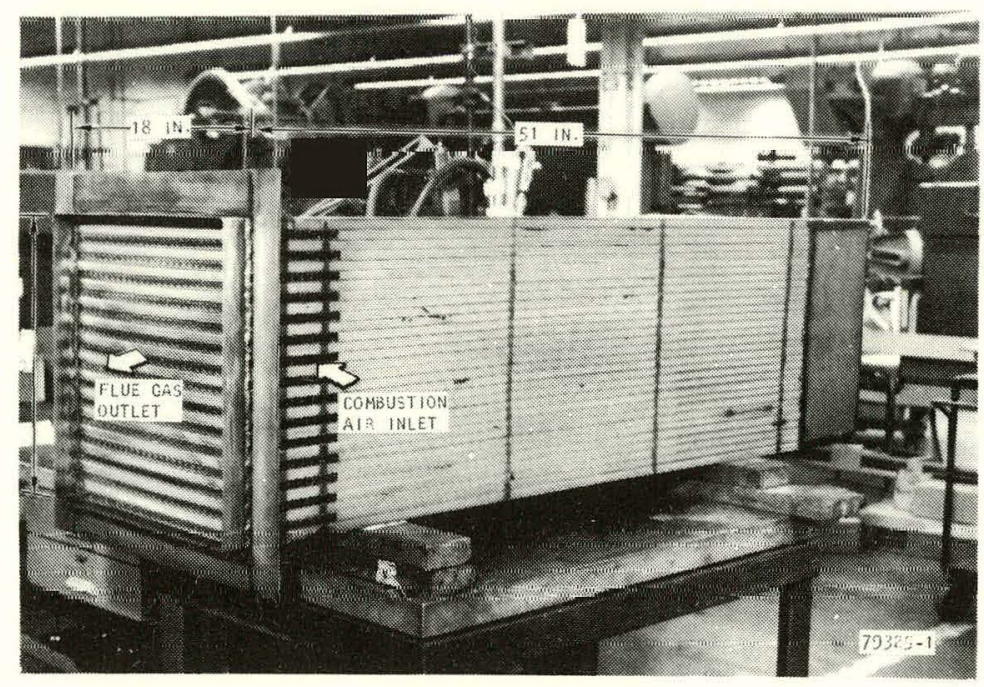

Figure 1-6. Completed Recuperator Core

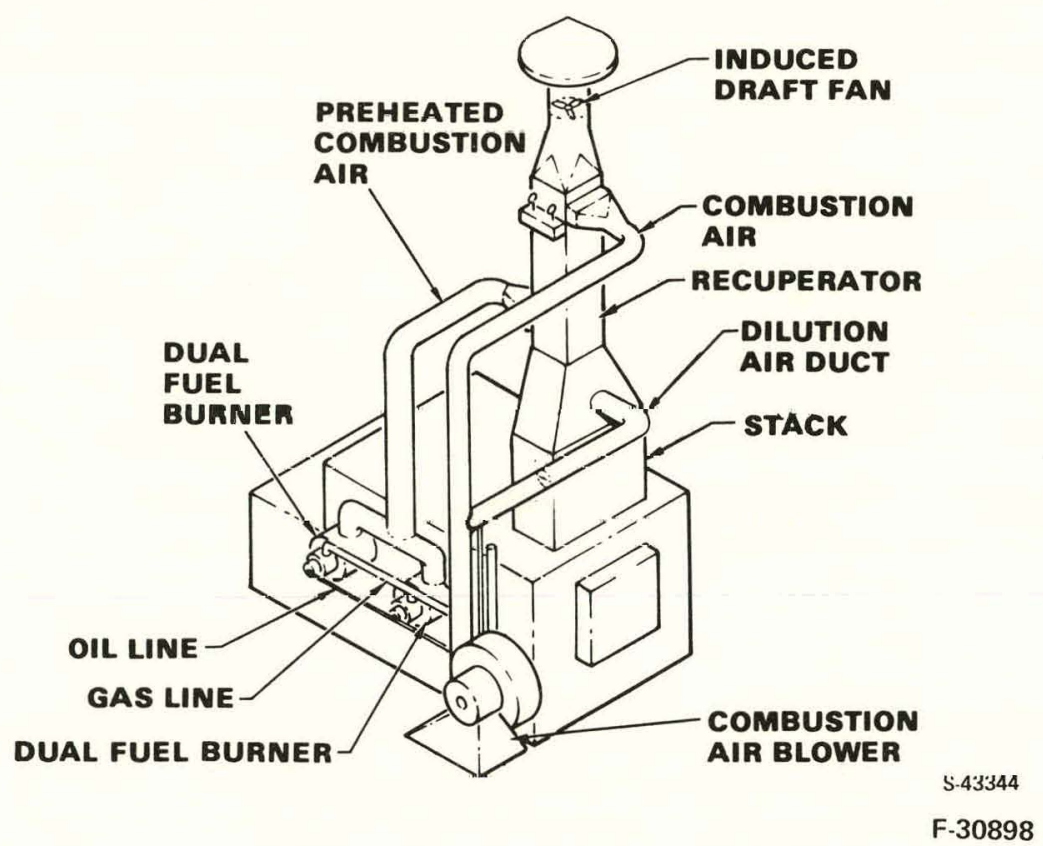

Figure 1-7. McGowan Aluminum Remelt Furnace After Modification for Recuperation 


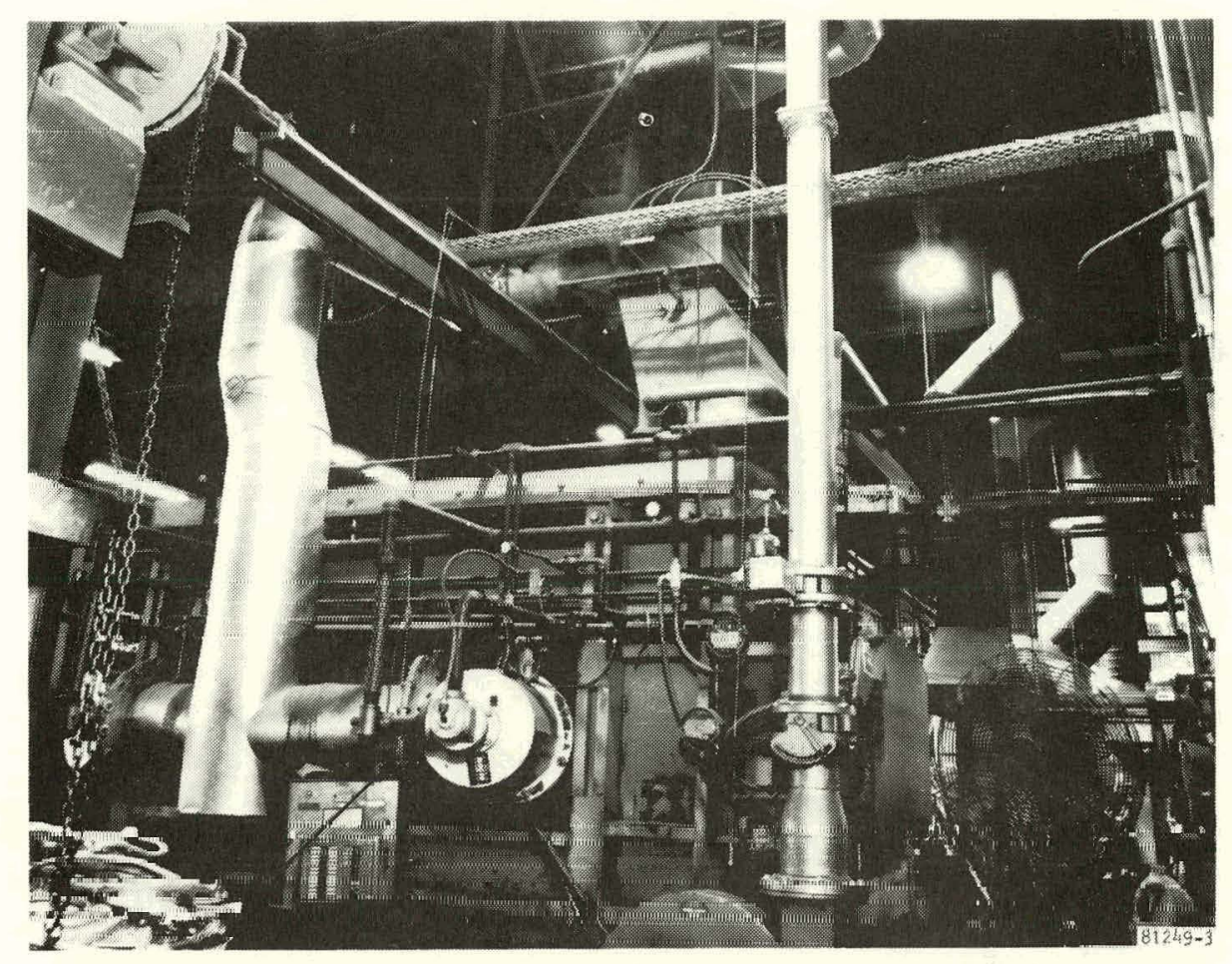

Figure 8. Modified McGowan Furnace; View From Northwest Showing Combustion Air Blower (Bottom), Blower/ Recuperator Air Transition Duct With Control Damper and Flowmeter Sections, Recuperator, Recuperator/Burner Air Transition Ducts, and Burners

\section{Demonstration Results}

The demonstration program was initiated in December 1977 when the 91percent-effectiveness plate-fin recuperator was installed on the gas-fired aluminum remelt furnace at the AiResearch Casting Company in Torrance, California. Production operation of the furnace was resumed in late January, following a 3-week period of adjustment and shakedown. After one year of recuperated furnace operation, results are as follows:

a. Fuel Savings: For the monitored 533 days of both unrecuperated and recuperated furnace operation, the average rate of furnace loading was 1.24 tons per day. At this loading rate, the specific energy consumption of the recuperated furnace is $16.7 \mathrm{million}$ BTU per ton of melt. The corresponding unrecuperated specific energy consumption is 24.6 million BTU per ton. Daily energy savings realized through recuperation is $9.8 \mathrm{million}$ BTU or 32.1 percent of the energy which would have been expended without recuperation. 
2. Cost Savings and Project Payback: Based on the current $\$ 0.21226$ per therm cost of natural gas, the annual return on investment is $\$ 7,589$. Exclusive of test instrumentation, the cost of furnace modification was $\$ 39,821$. This projects a 5.25 -year payback period which undoubtedly will be shortened by continued increases in the price of natural gas. The 1.24 ton/day average load rate represents only 10 percent of rated furnace capacity; at 67 percent of capacity, the annual savings would be increased to $\$ 12,800$ and the payback period decreased to 3 years.

3. Furnace Operation: No major operational or maintenance problems were encountered with the furnace or its ancillary equipment. The time required for charge melting was decreased as expected. This is due to the higher flame temperature induced by combustion air preheating. After 10 months of production, the burner required only a fuel flow adjustment.

4. Kecuperator tvaluation: Kecuperator pertormance was consistent throughout the year. At this writing there is no indication of leakage or fouling and the prognosis is continued satisfactory operation.

\section{PROSPECTS FOR COMMERCIAL APPLICATION}

The Task I survey report (77-14483) makes a clear case of the economic incentive of high-effectiveness flue gas recuperation. In some instances, there are technological limitations and areas of economic uncertainty which have resulted in past management reluctance to commit capital to waste heat recovery. Yet, the fact that lonq-term demand will exceed lonq-term supply makes it imperative that energy be conserved in every way possible. There are areas of technological development, e.g., the fields of high-temperature burners and heat exchangers, where inevitable advances in the state-of-the-art will increase the level of energy recovery and broaden the market for recovery systems. However, these improvements are not requisite to the protitable application of current technology to the problem. Experience over the last two years is that progressive plant managers are not only receptive to immediate efforts in the area of energy conservation, but also that they are fully capable of appreciating the difference between high-and low-level energy recovery.

The performance of the recuperator in the demonstration program is considered satisfactory. Performance was consistent over the year and there was no indication of plugging or leakage. It is unfortunate that furnace usage was at a low level because the savings and payback figures would be more auspicious at higher charge levels. Although it cannot be proved, it is believed that thermal cycling, the most severe structural condition imposed on the recuperator, is most severe under minimum load conditions. While it is true that plugging conditions might well be intensified by higher levels of usage, discussions with the aluminum industry indicate that the cleanliness of the charge is as important as the tonnage in this respect. In any event, plugging is by particulate matter which is easily removed with steam. 
In view of the above, it is believed that there is a definite place for the plate-fin recuperator in the industrial market. However, it is desirable to reduce cost so that the units will be cost-effective even in minimum-use situations at current fuel prices. One approach to cost reduction is through standardization, perhaps modularization. A second option is to replace the log-cabin construction of the demonstration recuperator with a formed-plate construction in which passage edge closure does not require bars or channels. The formed-plate construction has additional utility in that it is self-jigging for purposes of core assembly.

AiResearch has analyzed and prepared general, catalog-type performance curves for four tentative recuperator configurations. From plant surveys, it is clear that from a standardization standpoint new furnaces represent a more attractive market than retrofit situations. The most efficient installation of a recuperator is to mount it at the burner and eliminate the large, expensive hot air duct; integrated burner/recuperator assemblies should achieve standardization economy and simultaneously reduce installation cost.

AiResearch is currently negotiating to recuperate a box-annealing furnace at the United States Steel plant in Pittsburg, California. This negotiation entails the installation of 10 identical custom-designed recuperators on a furnace of 10,000,000 BTU/hr capacity. 


\section{SECTI ON 2}

\section{SYSTEM DETAIL AND DESIGN RATIONALE}

A McGowan reverberatory aluminum remelt furnace at the AiResearch Casting Company was selected for the demonstration of the flue gas recuperator. This furnace has a nominal rated burner capacity of $3.2 \mathrm{milli}$ on BTU per hour and can melt approximately 1000 pounds of aluminum per hour. It is used to supply holding pots from which about 30 percent of the foundry's production is presently poured. Both pig aluminum and gates and risers are melted in the furnace.

The recuperated system required (1) new burners capable of utilizing $1350^{\circ} \mathrm{F}$ air, (2) a new blower of higher capacity, (3) an induced-draft fan, (4) an exhaust-gas/air dilution system, (5) relocation of the burners, and (6) general rework of the combustion plumbing and control system. A schematic of the plumbing for the recuperated furnace is shown in Figure 2-1.

Air and fuel flow rates and exhaust gas dilution requi rements were determined by system thermal analysis (Appendix A). A mathematical model of the unrecuperated furnace was generated with classical heat transfer theory and empirical data correlations from References 2-7. The model was used to calculate exhaust gas temperatures which were subsequently compared wi th measured temperatures recorded in the furnace stack. The assumptions on which the model was based were reevaluated and the model was modified to improve the correlation between analysis and test. At this point, the model was revised to simulate the recuperated furnace. Wi th near-optimum unrecuperated furnace operation as a base, the fuel flow requi rement was calculated for recuperated furnace operation with equivalent charge heating. This analysis was based on stoichiometric recuperated combustion, i.e., no excess ai $r$.

Since the accuracy of the analysis is not precise, the fuel and air flows were increased by 19 percent to ensure that furnace capacity was not inadvertently reduced in the course of recuperation. This does not have major impact on fuel economy because furnace capacity is not utilized on a continuous basis; at higher flow, the response is faster and the furnace spends more time on low-fire.

The selected fuel and air flows were 91 and $1561 \mathrm{lb} / \mathrm{hr}$, respectively. Recuperator performance requirements are listed in Table 2-1. In designing the unit, heat transfer in the core crossflow end sections was disregarded and a 20-percent margin of safety was applied to the heat transfer coefficient in the counterflow section. This conservatism was intended to compensate possible deleterious effects of plugging or fouling and additional loss of performance due to flow maldistribution. When (1) the end sections are considered, (2) the margin is removed, and (3) the flow distribution is evaluated, the calculated steady-state effectiveness is increased from 85 percent to 91 percent. The latter has been consistently realized near the end of the heating cycle and there has been no discernable performance deterioration over the 12 months of recuperated furnace operation.

A finite-difference computer thermal analysis was executed to evaluate thermal stresses in the recuperator plates and bars. This and the desire to improve 

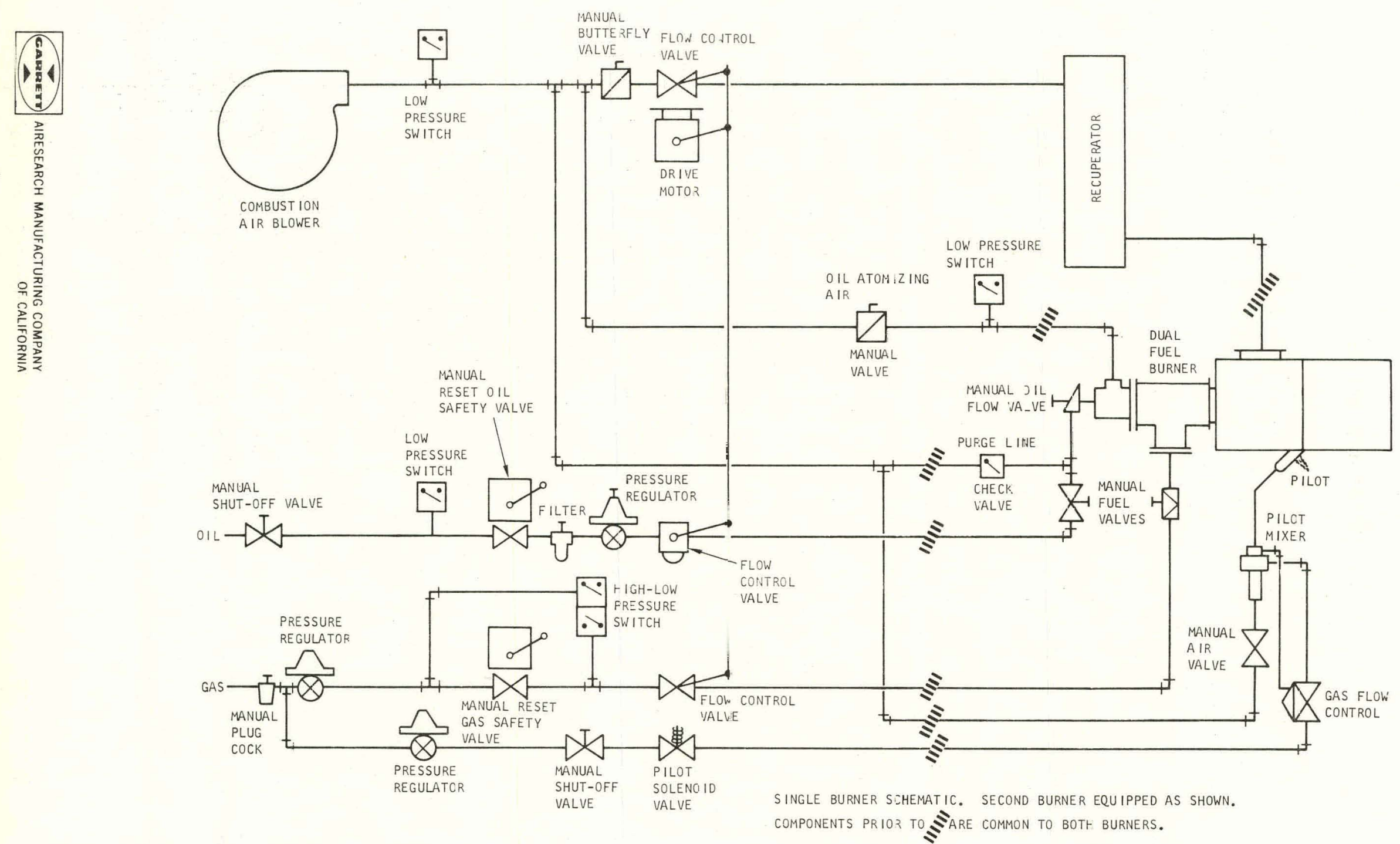
MCGOWAN FURNACE RECUPERATOR PERFORMANCE REQUIREMENTS

Air flow rate, $\mathrm{lb} / \mathrm{hr}$

Exhaust gas/secondary air flow rate, $1 \mathrm{~b} / \mathrm{hr}$

1994

Air inlet temperature, ${ }^{\circ} \mathrm{F}$

100

Gas inlet temperature, ${ }^{\circ} \mathrm{F}$

1550

Airside heat transfer effectiveness

0.850

Air outlet temperature, ${ }^{\mathrm{O}} \mathrm{F}$

Gas outlet temperature, ${ }^{\circ} \mathrm{F}$

725

Air inlet pressure, psia

15.0

Air pressure loss, inches of $\mathrm{H}_{2} \mathrm{O}$

4.0

Gas inlet pressure, psia

14.4

Gas pressure loss, inches of $\mathrm{H}_{2} \mathrm{O}$

4.0 
high-temperature oxidation resistance resulted in the use of dual-material plates which feature Hastelloy $S$ wedges along the exhaust gas inlet face of the core. 


\section{SECTION 3}

\section{FABRICATION AND INSTALLATION}

\section{RECUPERATOR DESCRIPTION}

The stainless steel recuperator is designed to an overall counterflow configuration which is optimum in maximizing the mean temperature difference between the flow streams and also in limiting thermal stresses in the core. Figure 3-1 shows that the air flow is supplied and discharged from opposite sides of the core. Lateral distribution and collection are through mitered triangular fin sections which are oriented perpendicular to the counterflow fins.

The recuperator plates are of $0.025 \mathrm{in}$. thick Hastelloy $\mathrm{S}$, butt-welded to $0.025 \mathrm{in.}$ thick AISI 444 ferritic steel. The Hastelloy comprises approximately 25 percent of the plate at the gas inlet end of the recuperator to provide creep strength and corrosion resistance. 0ther parts are of AISI 409 steel of gauges consistent with the mating ducting. These material selections are based on a finite-difference computer thermal analysis and experience acquired on other automative and industrial gas turbine recuperator development programs.

The recuperator fins are stamped with punch-press dies. For the air fins, the mitered end cuts are with an abrasive wheel. These fins are deburred manually to ensure that their heat transfer and flow friction characteristics are consistent. Nickel-base braze alloy in slurry form is applied to the plates by spraying. The recuperator core is assembled by stacking alternate layers of gas fins, plates, and air fins in a fixture; flow passage edge closure is with $0.025-i n$. thick channels to minimize transient thermal response time and thereby attain compatibility with plate response.

After assembly, the core is brazed in a hydrogen atmosphere. The recuperator is then completed with welded attachment of transition ducts, flanges and mounting brackets. Figure 3-2 shows the brazed core assembly before the addition of ducts.

Figure 3-3 shows the recuperator installed in a carbon steel frame which is supported from building roof structure. The recuperator is suspended from brackets at the exhaust gas exit end of the core. This arrangement permits unrestrained thermal expansion in the vertical direction. Dimensional allowances in the frame accommodate thermal growth in the other planes.

Flange attachments for the stack and combustion air ducting are a part of the structural frame, thus eliminating the need for expansion joints. Sealing is provided by insulation which was applied in plastic form and subsequently cured to form a rigid coating. 


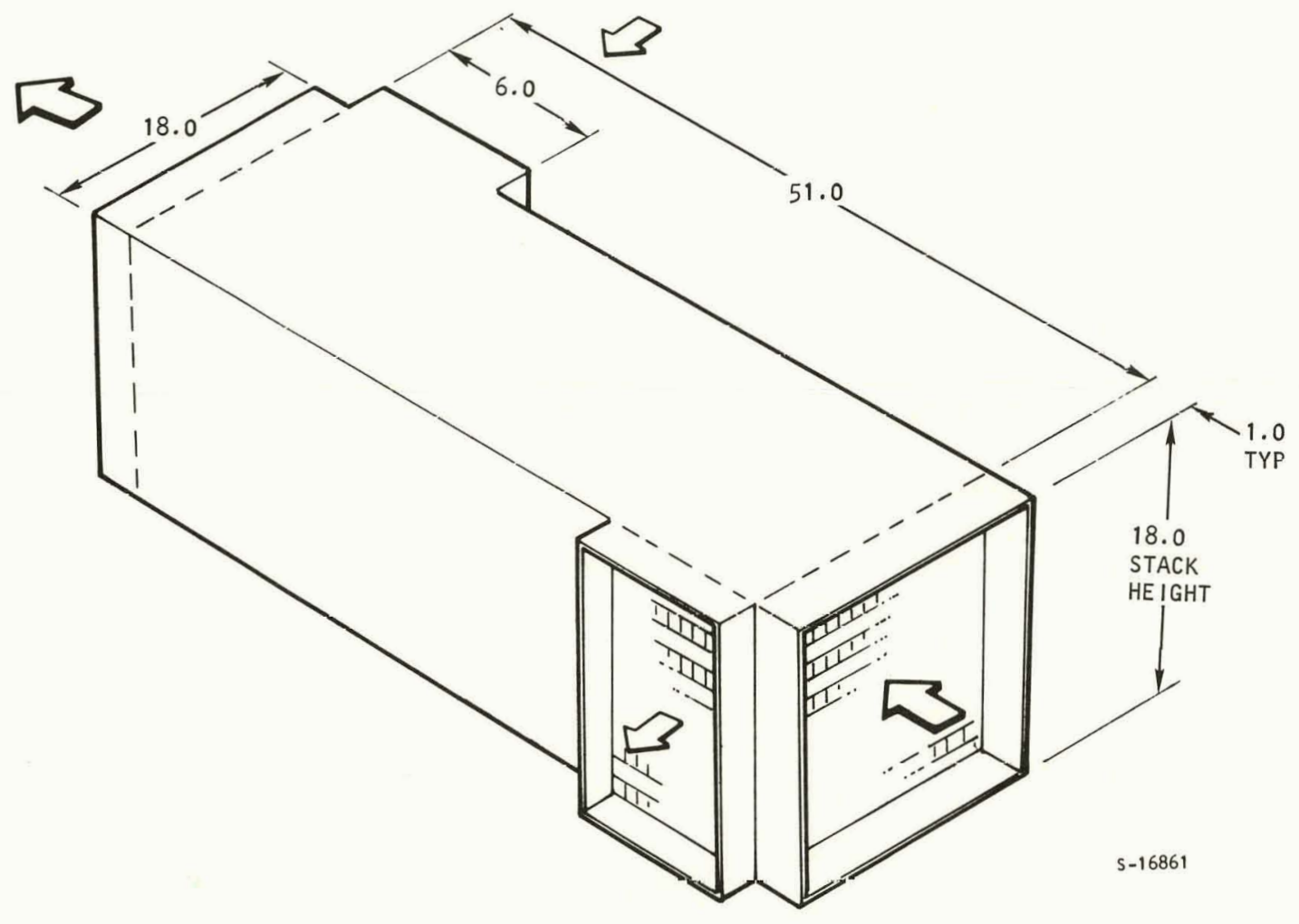

Figure 3-1. McGowan Furnace Recuperator Core Dimensions

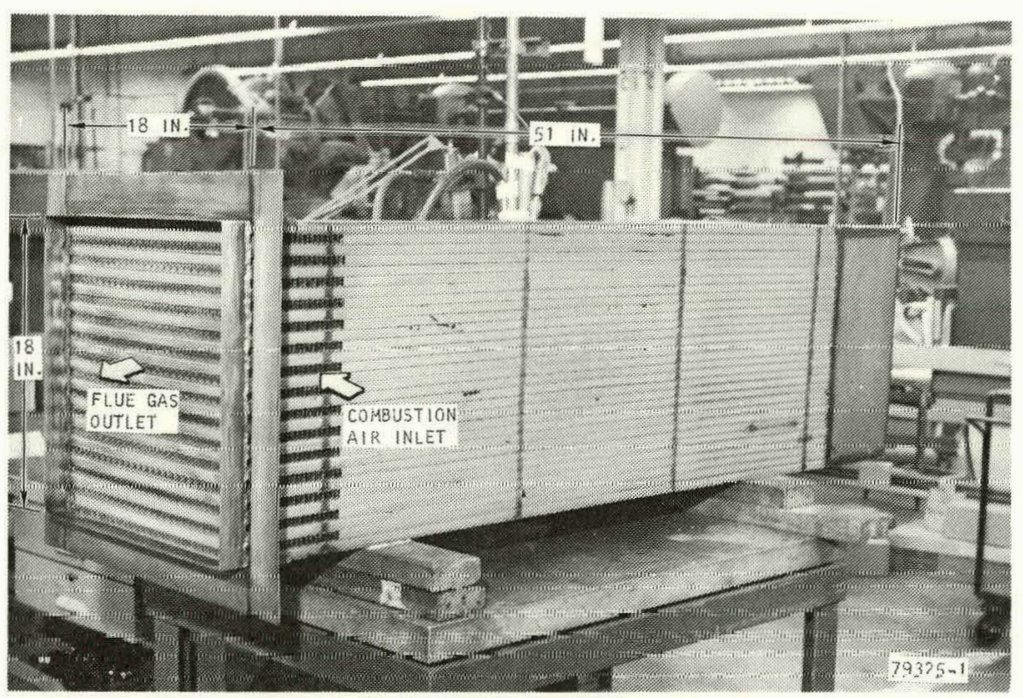

Figure 3-2. Completed Recuperator Core 


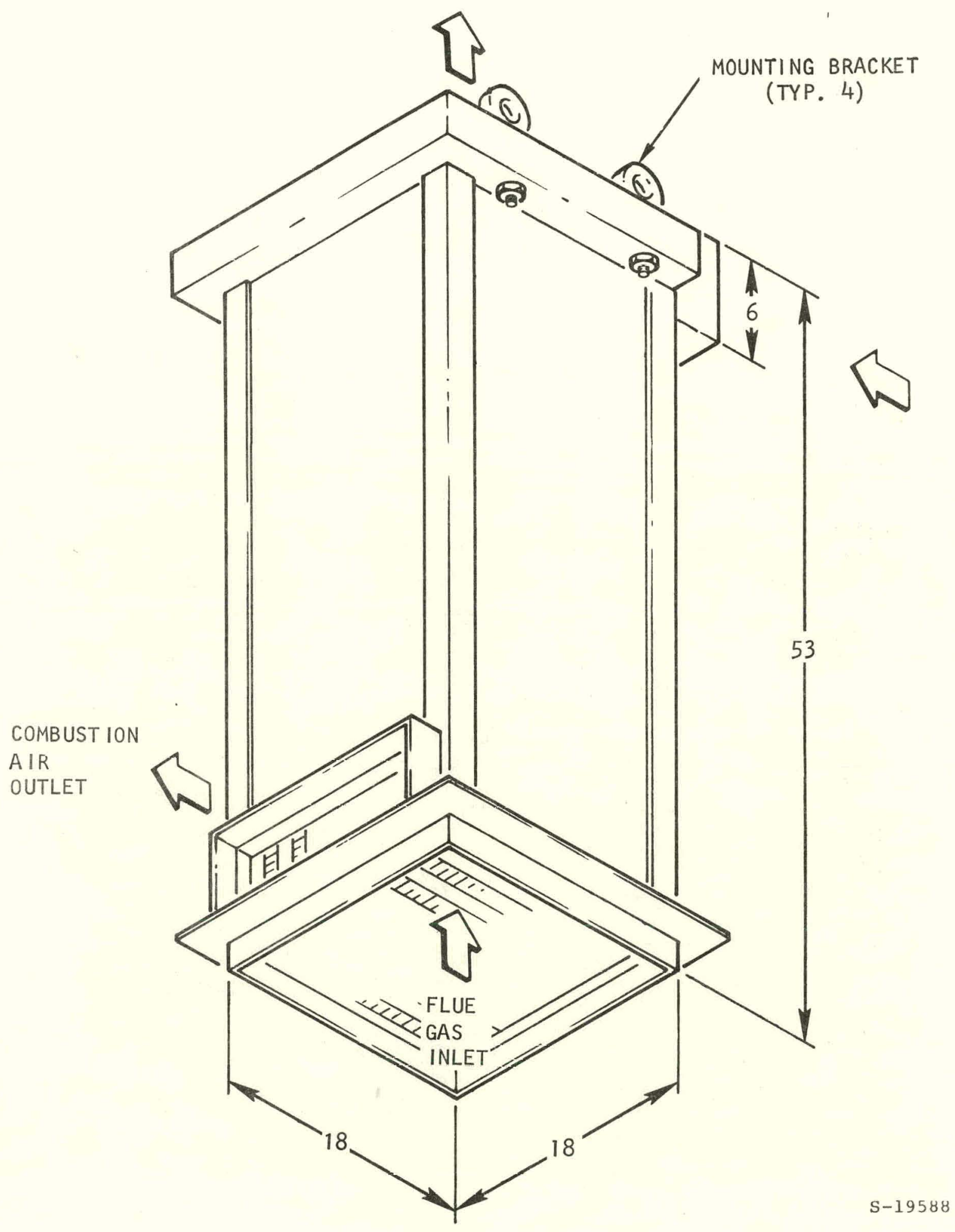

Figure 3-3. Recuperator Installation 
As noted in Section 2, the preheated combustion air provided by the recuperator requires the use of new burners capable of utilizing the $1350^{\circ} \mathrm{F}$ air, a new blower, an exhaust fan, and extensive modification of the furnace, plumbing and controls. The recuperated installation is shown pictorially in figure 3-4. In this isometric sketch, various valves, safety items, and controls have been omitted in the interest of simplicity.

Figures 3-5 through 3-10 show the furnace before modification for recuperation. Figure $3-5$ is an overview which shows a typical loading operation using the large well on the east end. Figure 3-6 shows the south side with the old combustion air blower, controls, and fuel and air piping to the roof-mounted burners. The dip well from which molten aluminum is wi thdrawn is on the left. Figure 3-7 shows the southwest corner, the rear door into the dry hearth and flue area, and the original furnace hood and stack. Figure 3-8 shnws the north side of the furnace. The two doors were used for cleanout. Figure 3-9, also from the north, shows the details of the old hood (which was designed to ingest stack cooling air), the sheet metal stack and the furnace flue, which is lined wi th firebrick. Figure 3-10 shows the stack and door areas which were modified to accept the recuperator and $1350^{\circ} \mathrm{F}$ burners.

Figures 3-11 through 3-14 show the furnace in various stages of modification. Figure 3-11 shows the furnace after removal of the cleanout doors and exhaust stack. At this time, a steel beam was installed in the roof and the recuperator was suspended by cables from two crossbeams between the beam and existing structure. The new burners were mounted in the cleanout door openings and the new combustion air blower was installed at the northwest corner of the furnace. Gas dild vil piping and the ducts were attached and thermocouples and pressure taps were installed in the ductwork; a tray was mounted between the ductwork and the instrumentation subpanel to support the pressure lines and thermocouplc wires.

Figures 3-15 through 3-17 show the completed installation. Figure 3-15 shows the vertical combustion air supply pipe and air control valves. At the top of the pipe, the airflow orifice is visible. The gas flow orifice is seen in the horizontal gas supply pipe coming from the right edge of the picture. The gas and oil control valves are hidden behind the combustion air supply pipe. On the right side of Figure 3-17, the gas control valves can be seen adjacent to the electrical box containing the motor starters and safety controls. Above these items is the instrument subpanel. The back side of this subpanel is visible in the photograph. From this panel a conduit runs to the basement location of the instrument panel. Within the conduit, thermocouple wire carries the temperature signals and a cable of twisted wi re pairs carries 4 to $20 \mathrm{mil}$ signals from the pressure transmitters to the display panel.

Figure 3-18 shows some typical pressure and temperature probe installations. The lower probes measure the flue temperature and pressure. Four thermocouples are installed in a row to sense flue temperature. A fifth thermocouple is installed in the center. The latter is an aspirating thermocouple which draws 


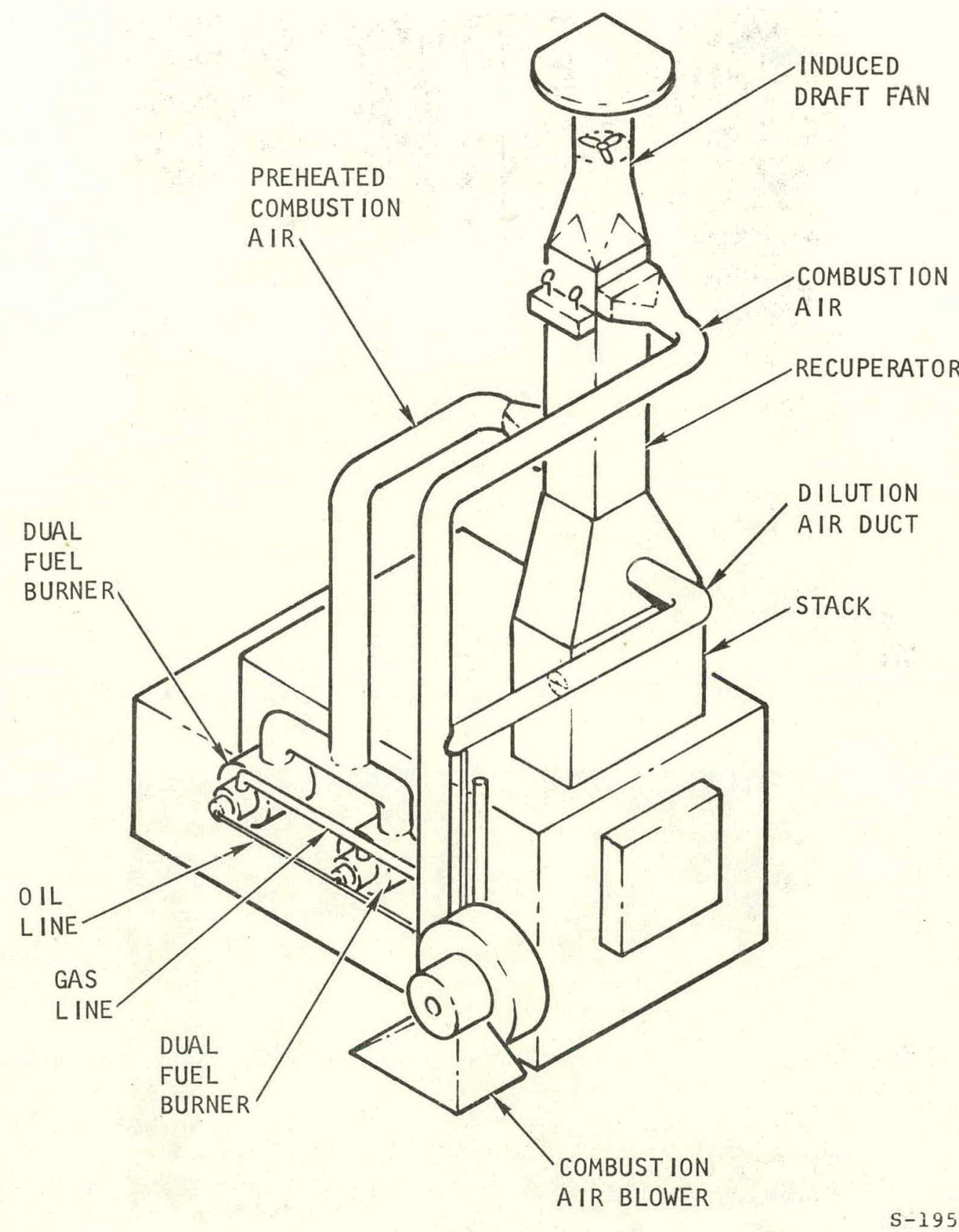

S-19587-A

Figure 3-4. McGowan Alumi num Remelt Furnace After Modification for Recuperation 


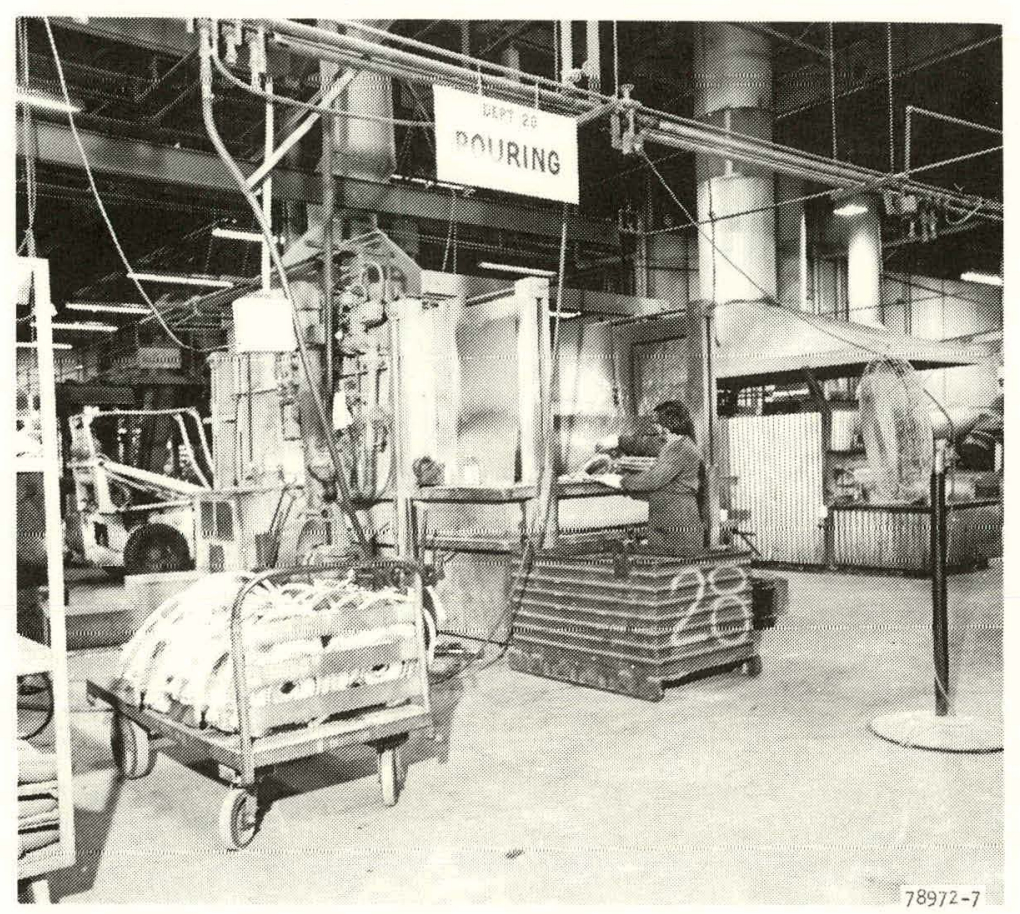

Figure 3-5. Overview of McGowan Furnace Before Modification for Recuperation

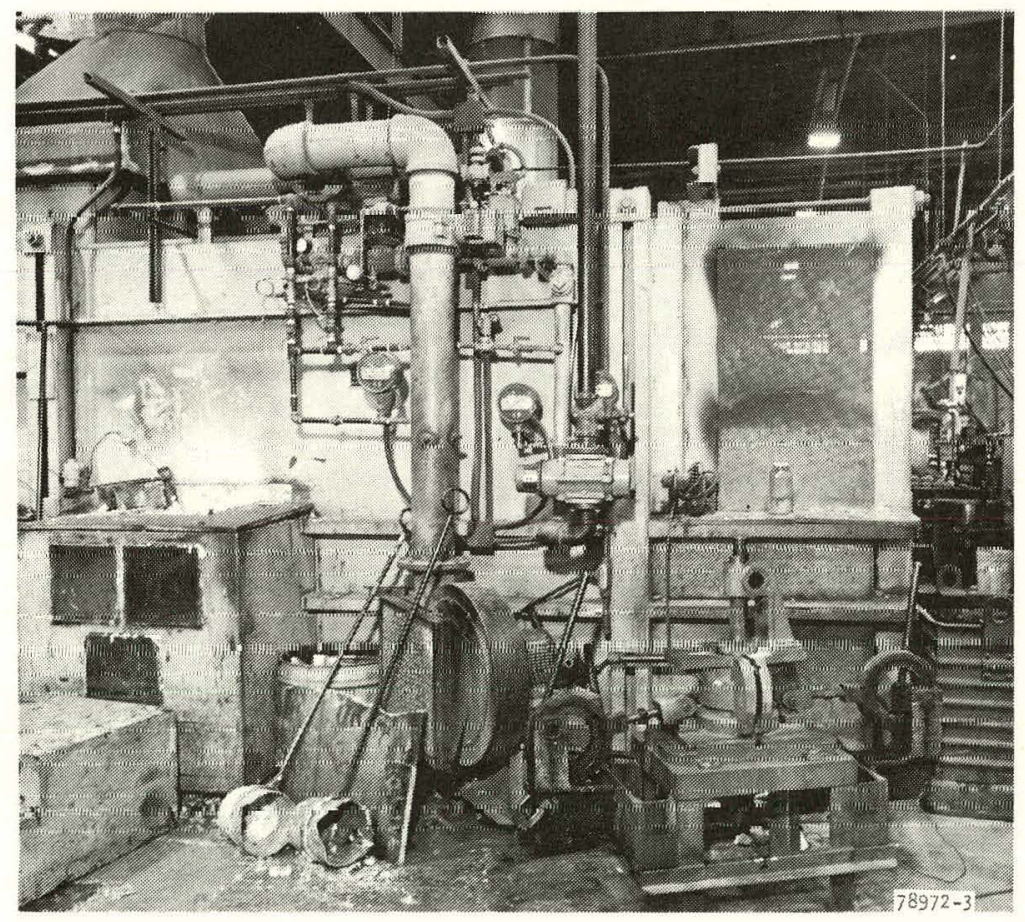

F-26660

Figure 3-6. Unrecuperated Combustion Air and Gas Supply 


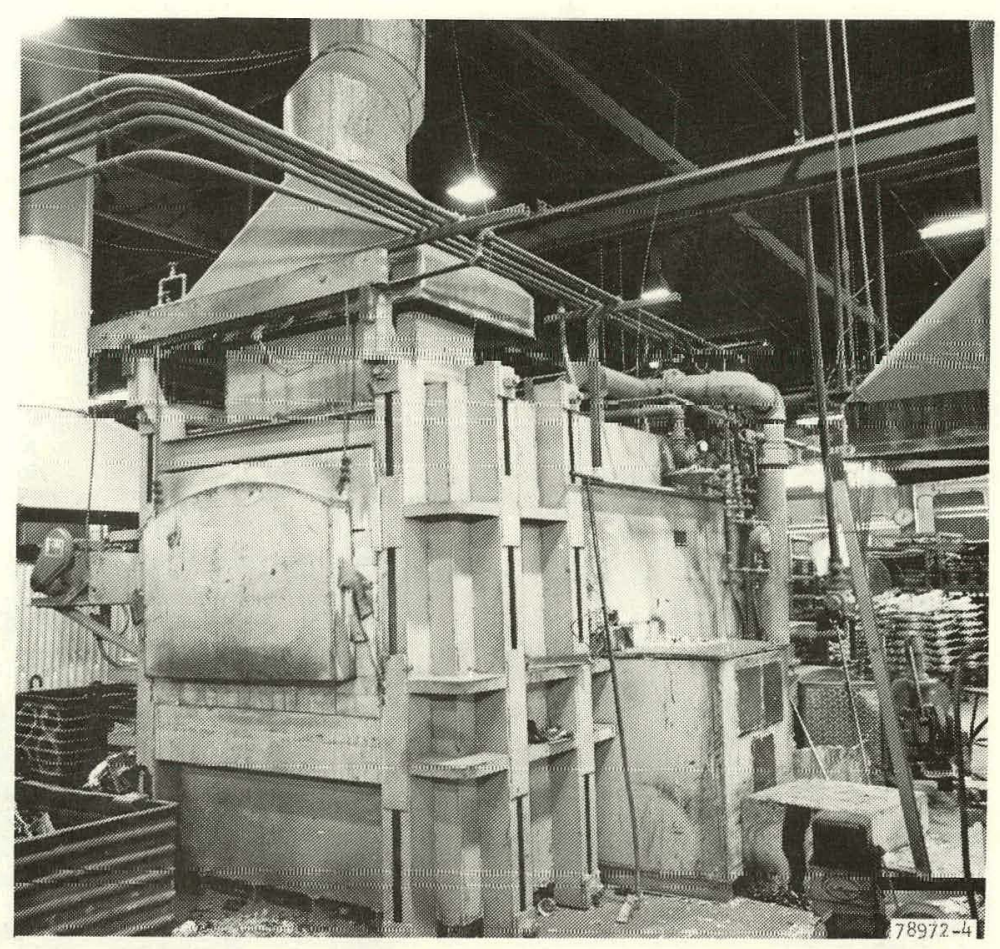

Figure 3-7. McGowan Rear Door (Before Furnace Modification)

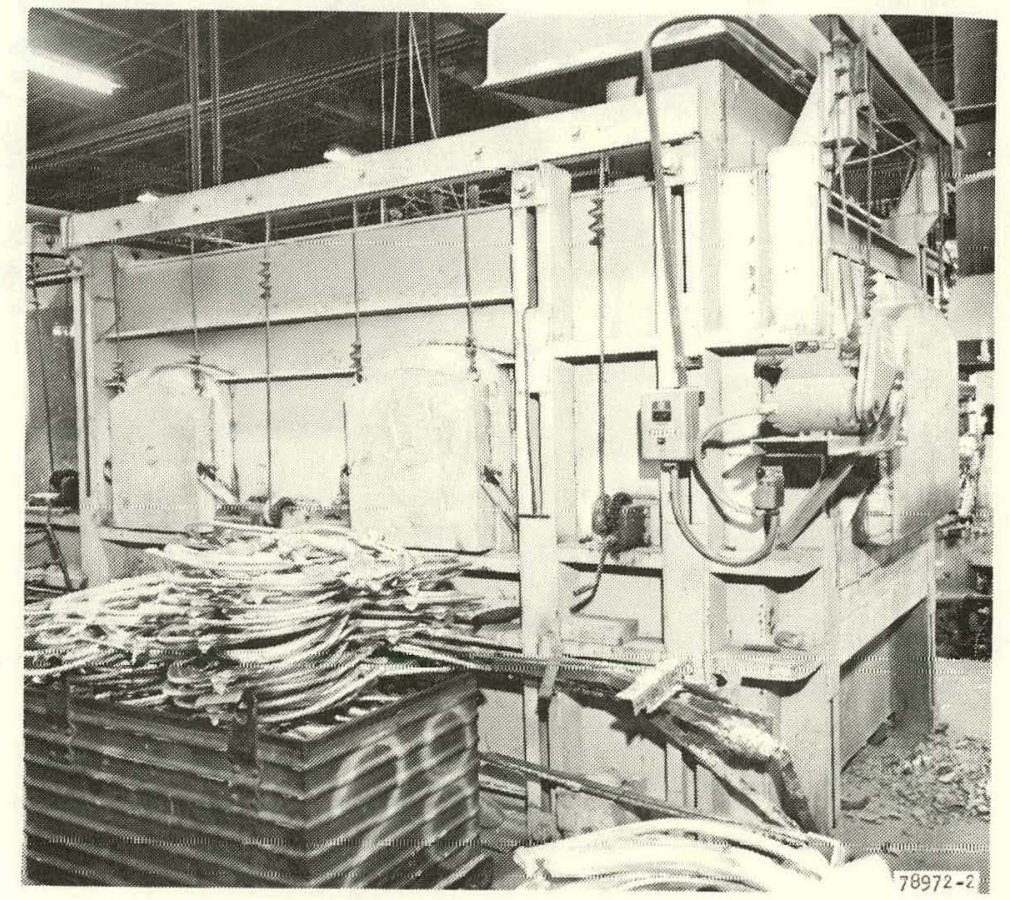

F-26661

Figure 3-8. McGowan North Si de Clean Out Doors (Before Furnace Modification) 


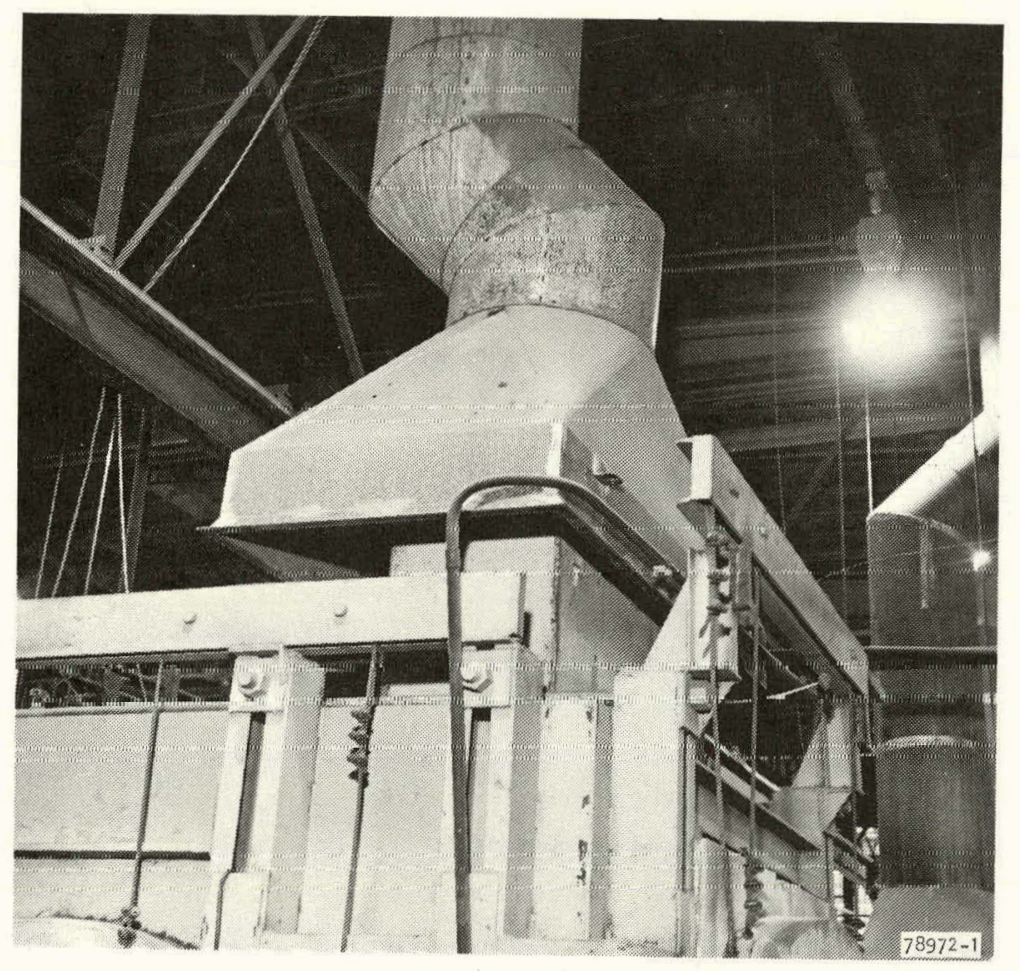

Figure 3-9. McGowan Flue and Stack Before Modification 


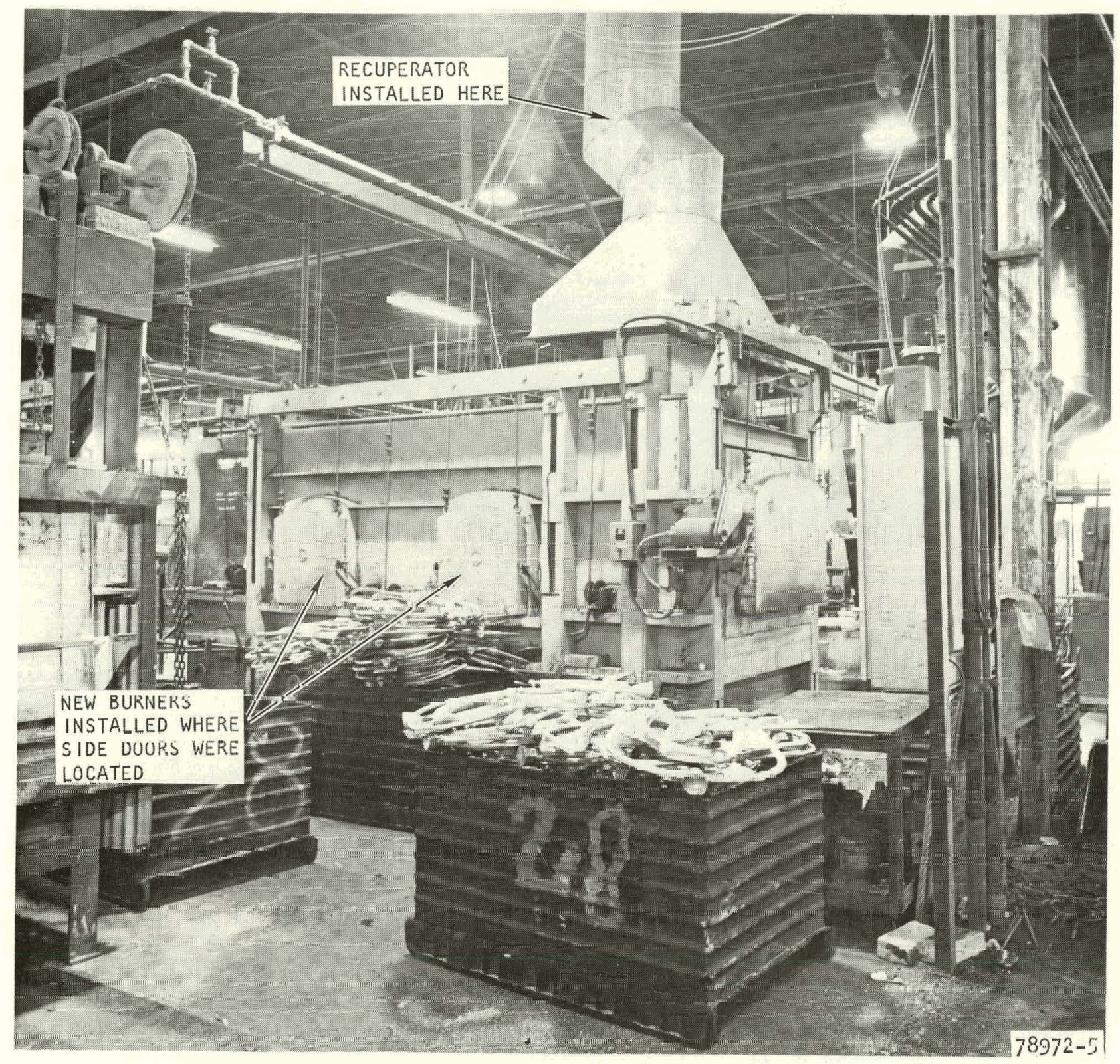

$F-26131-A$

Figure 3-10. McGowan Alumi num Remelt Furnace Modification for Recuperation 


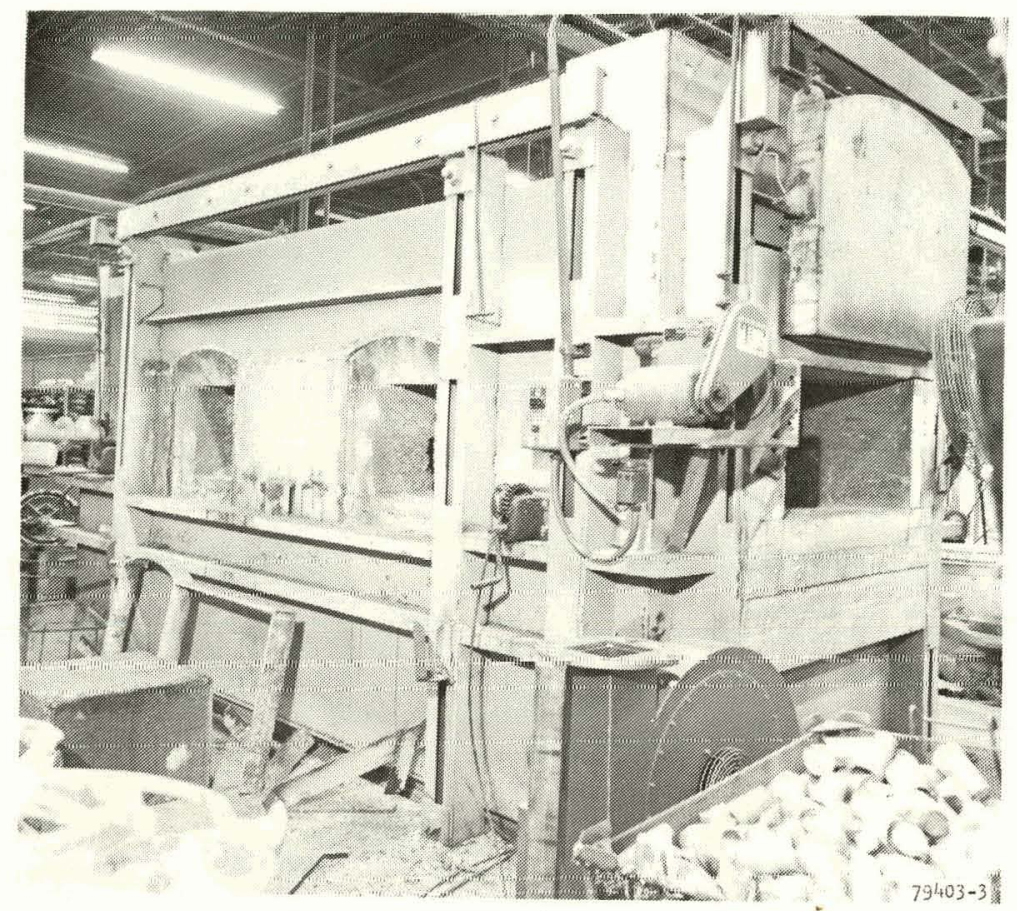

F.26662

Figure 3-11. Furnace During Disassembly

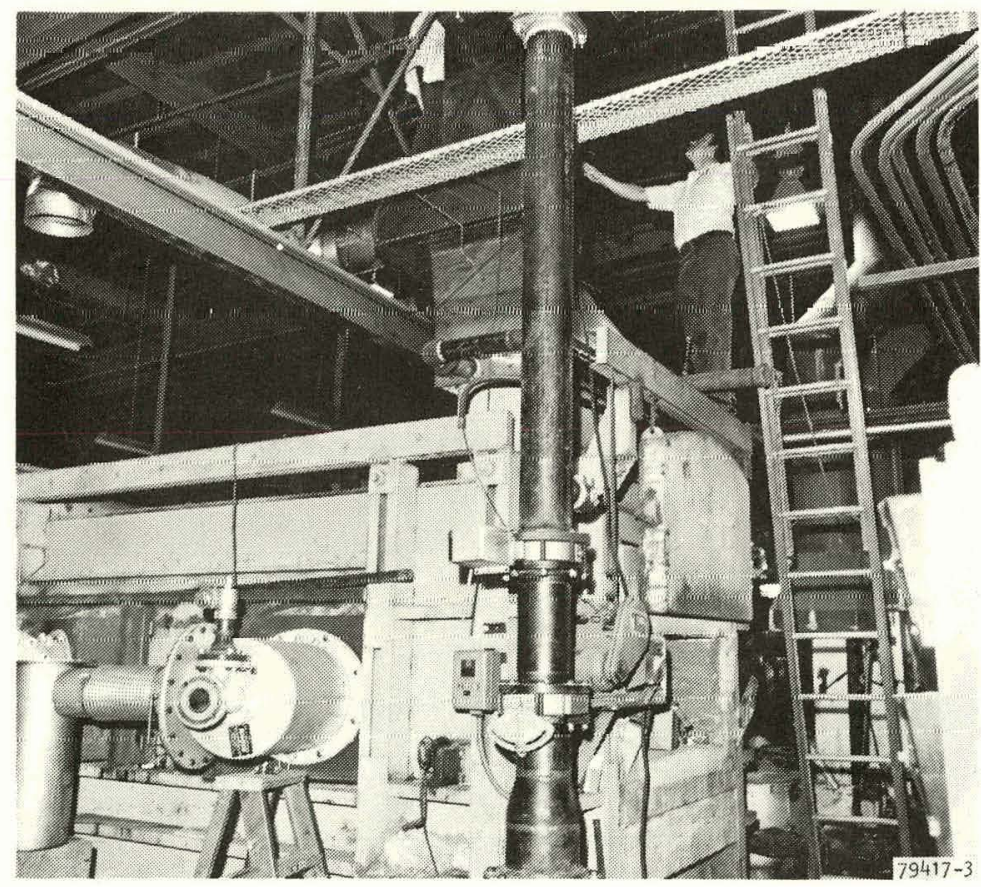

Figure 3-12. Combustion Air Supply Pipe, Recuperator Behind 


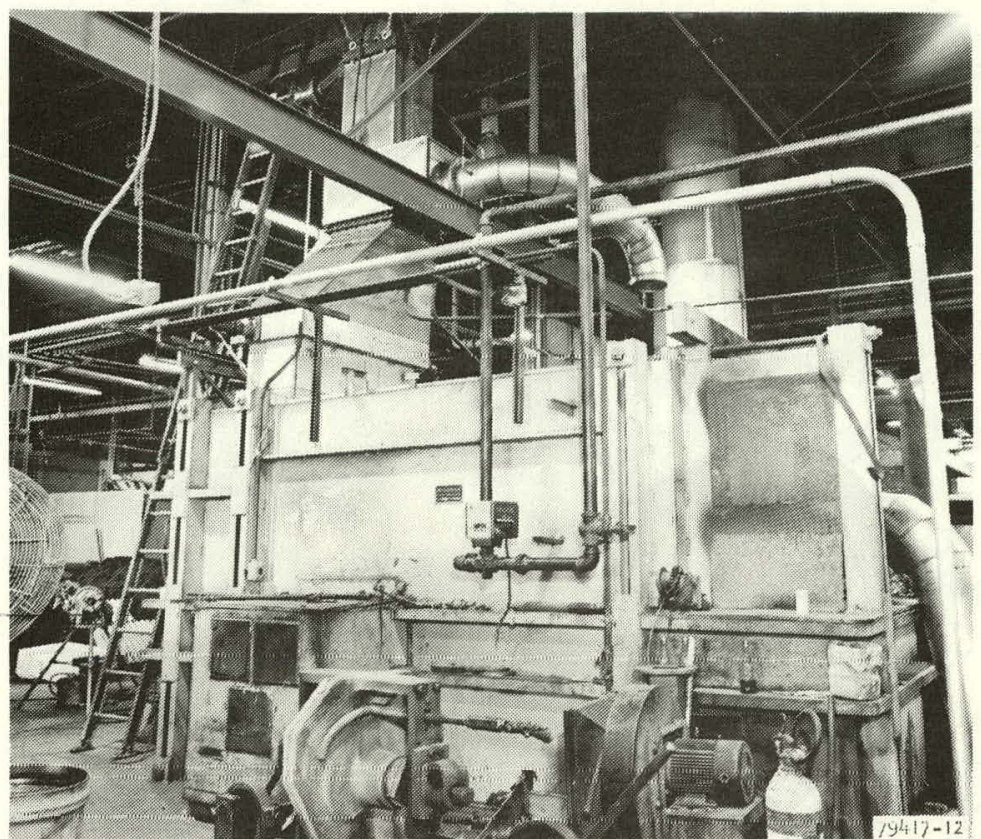

F-26663

Figure 3-13. View from South During Furnace Modification

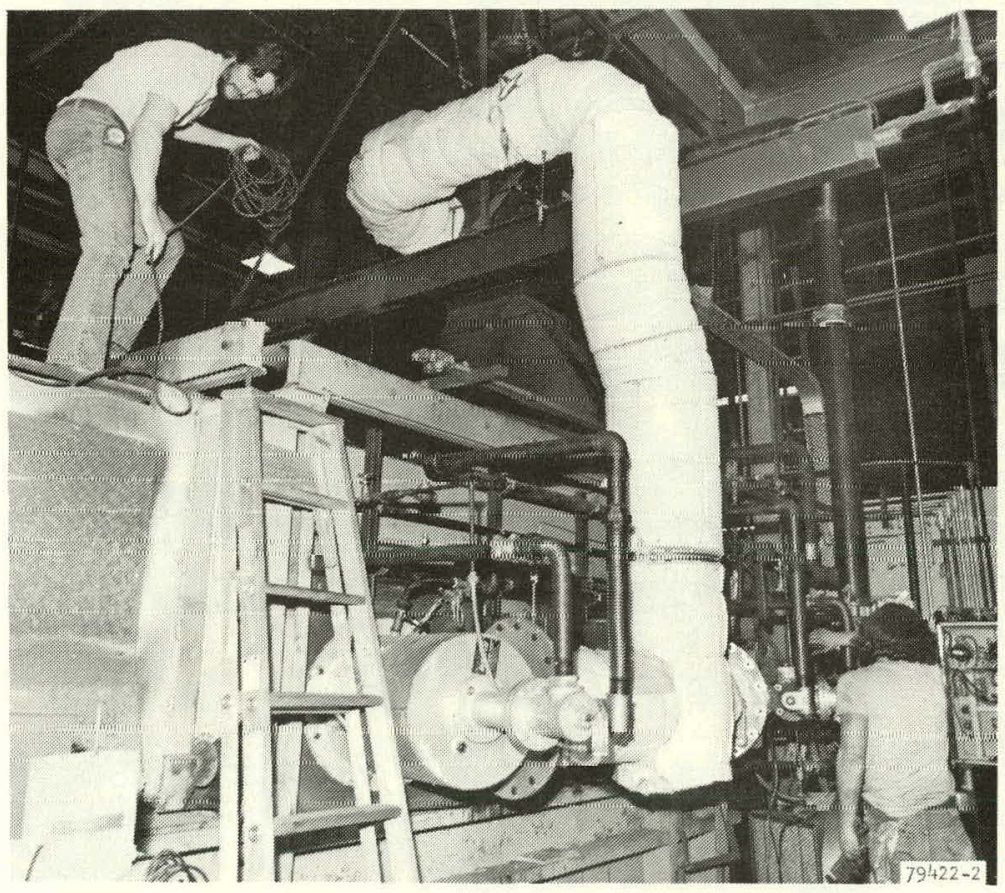

Figure 3-14. Insulation of Combustion Air Piping 


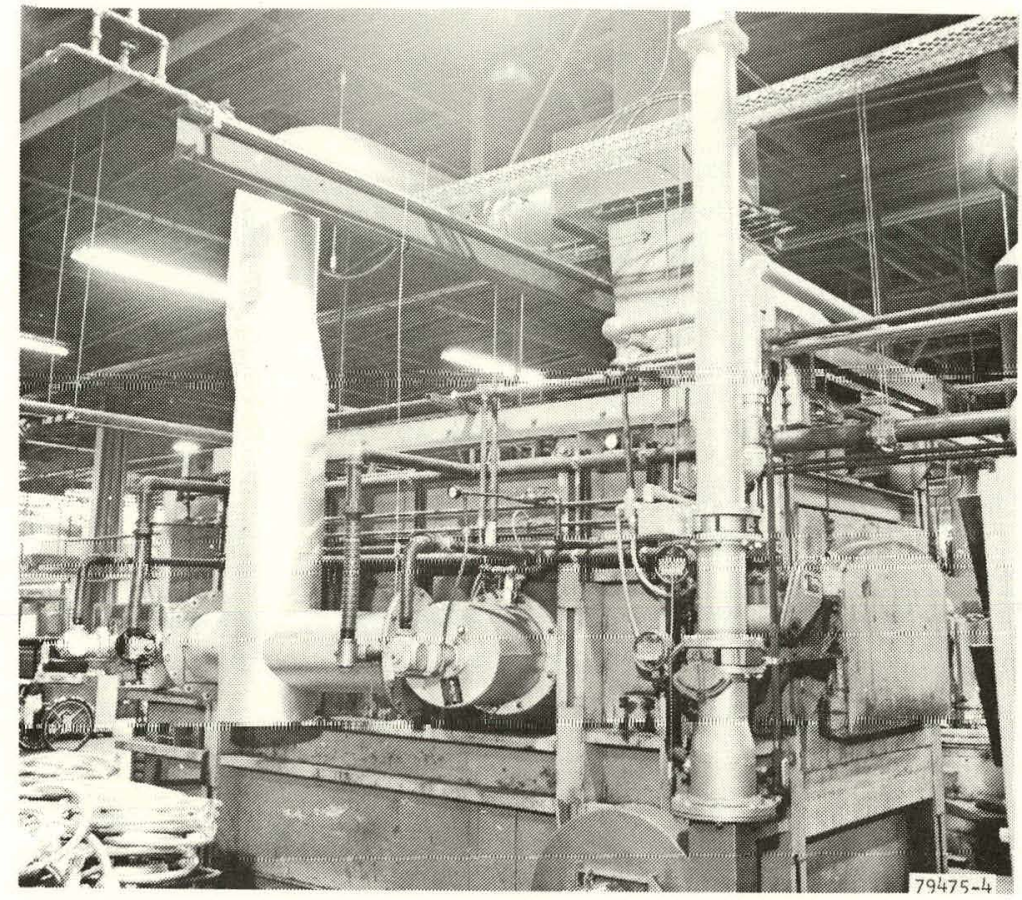

F.26664

Figure 3-15. Overview of Completed Installation from Northwest

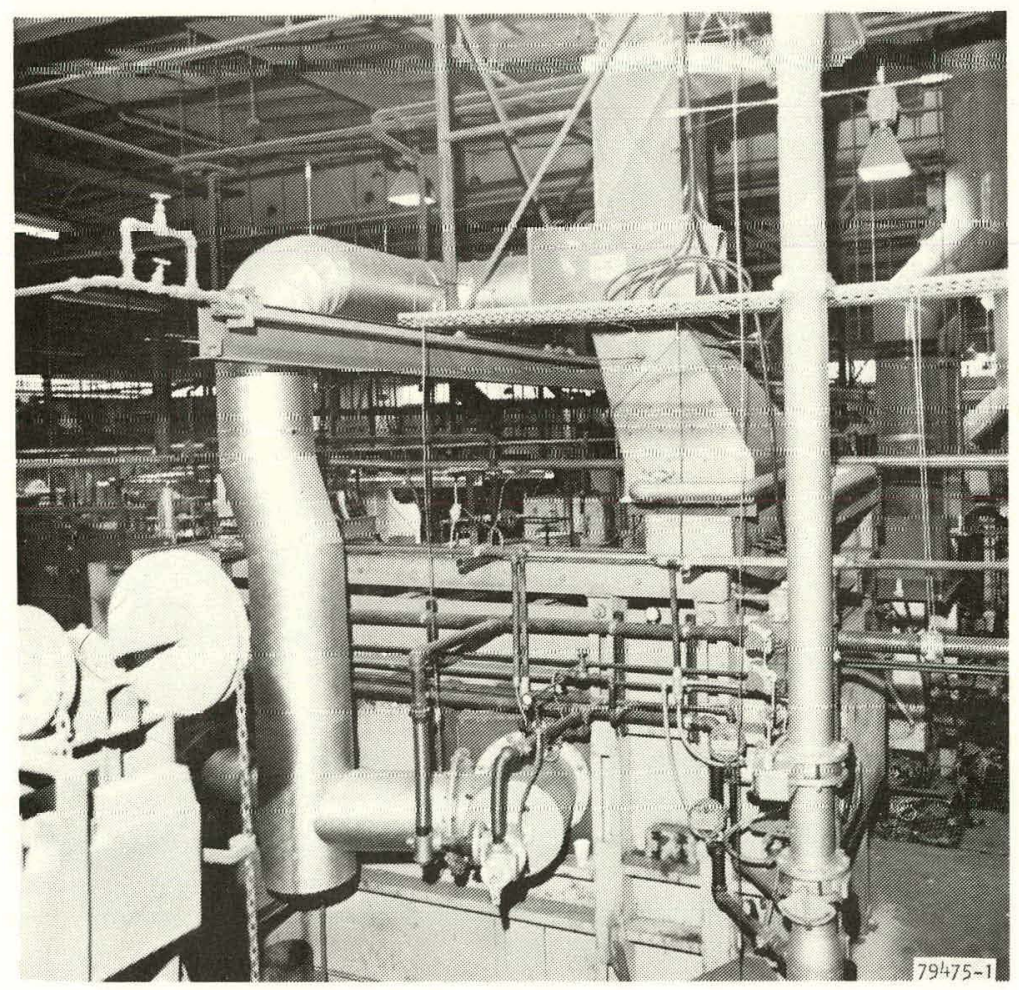

Figure 3-16. View of Recuperator from North 


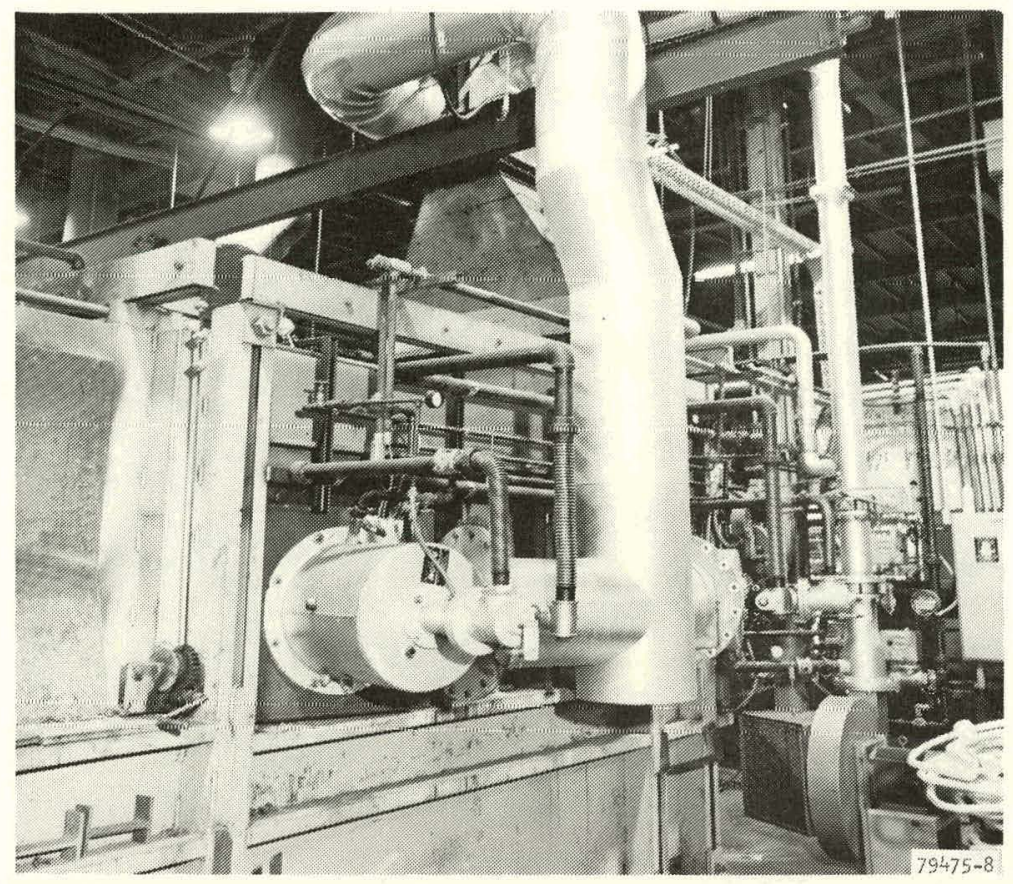

Figure 3-17. Burners and Hot Air Ducting

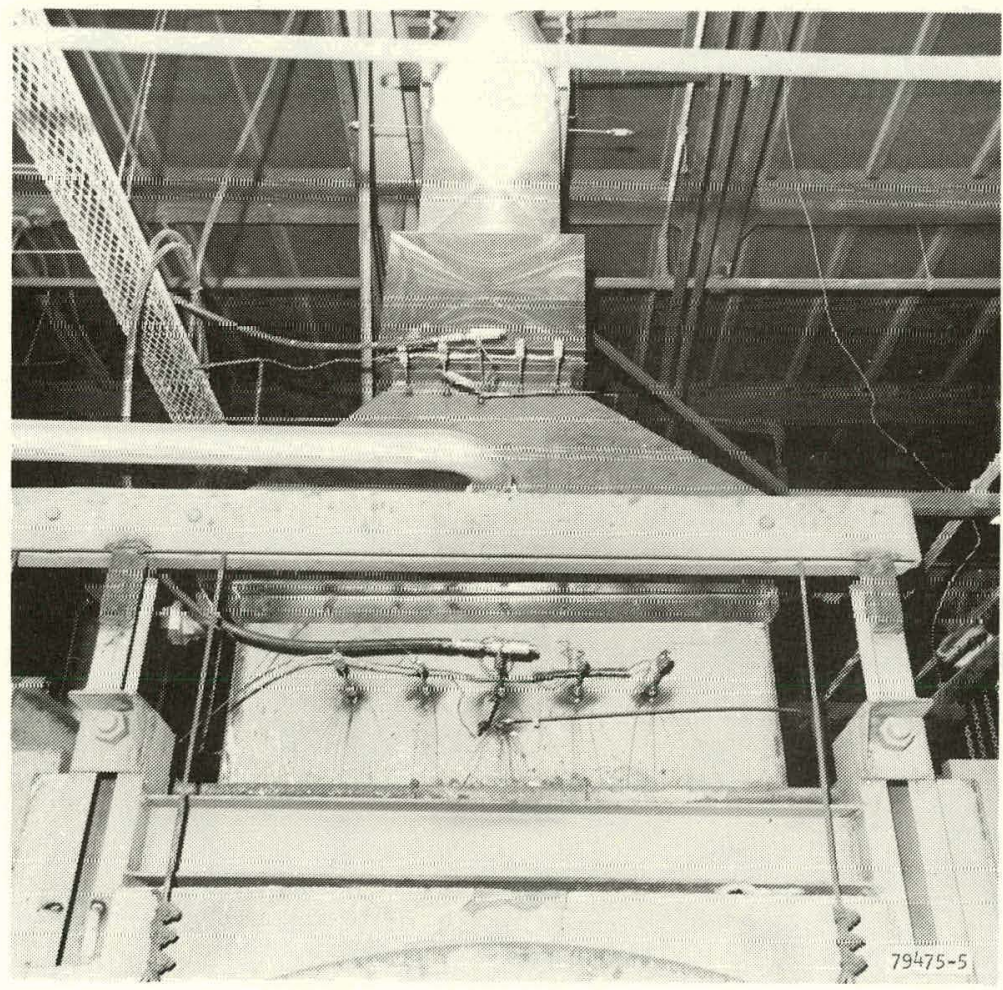

Figure 3-18. Pressure and Temperature Probes 
gas over the shielded junction to eliminate radiation effect. A small airdriven eductor provides suction to draw the sample. The air hose and eductor are visible in the photograph. Any of the five temperatures can be read in the basement by selecting the correct switching station number on the digital readout panel. Pressure in the flue is measured by averaging four taps, one on each side of the flue. A $1 / 4 \mathrm{in}$. copper line averages the four taps and carries the pneumatic signal to the pressure transmitter. The temperature probes at the entrance to the recuperator can be seen at the top of the tapered transition duct. Additional probes can be seen at the top of the photo.

Also visible in the left center of Figure 3-18 is a three-inch pipe which carries dilution air to the flue to maintain the recuperator gas inlet temperature at or below $1550^{\circ} \mathrm{F}$. The air is injected through three-inch diameter manifolds on each side of the flue. Dilution air flow is controlled by a motnr-driven valve in the common supply pipe upstream of the two-pipe junction. Regulation is provided by a controller which responds to a signal from a temperature probe in the exhaust transition below the recuperator. A second controller provides redundant protection for the recuperator by shutting down the furnace if the recuperator exhaust gas inlet temperature exceeds $1650^{\circ} \mathrm{F}$. The characteristic of the blower is such that the combustion air flow is essentially unaffected by dilution fluctuations.

On the roof of the foundry building, the recuperator exhaust stack is connected to a new exhaust fan which is wired to operate when the furnace is on high-fire. This fan compensates the gas side pressure drop of the recuperator and thereby avoids pressurization of the furnace. Figure 3-19 shows the fan installation. 


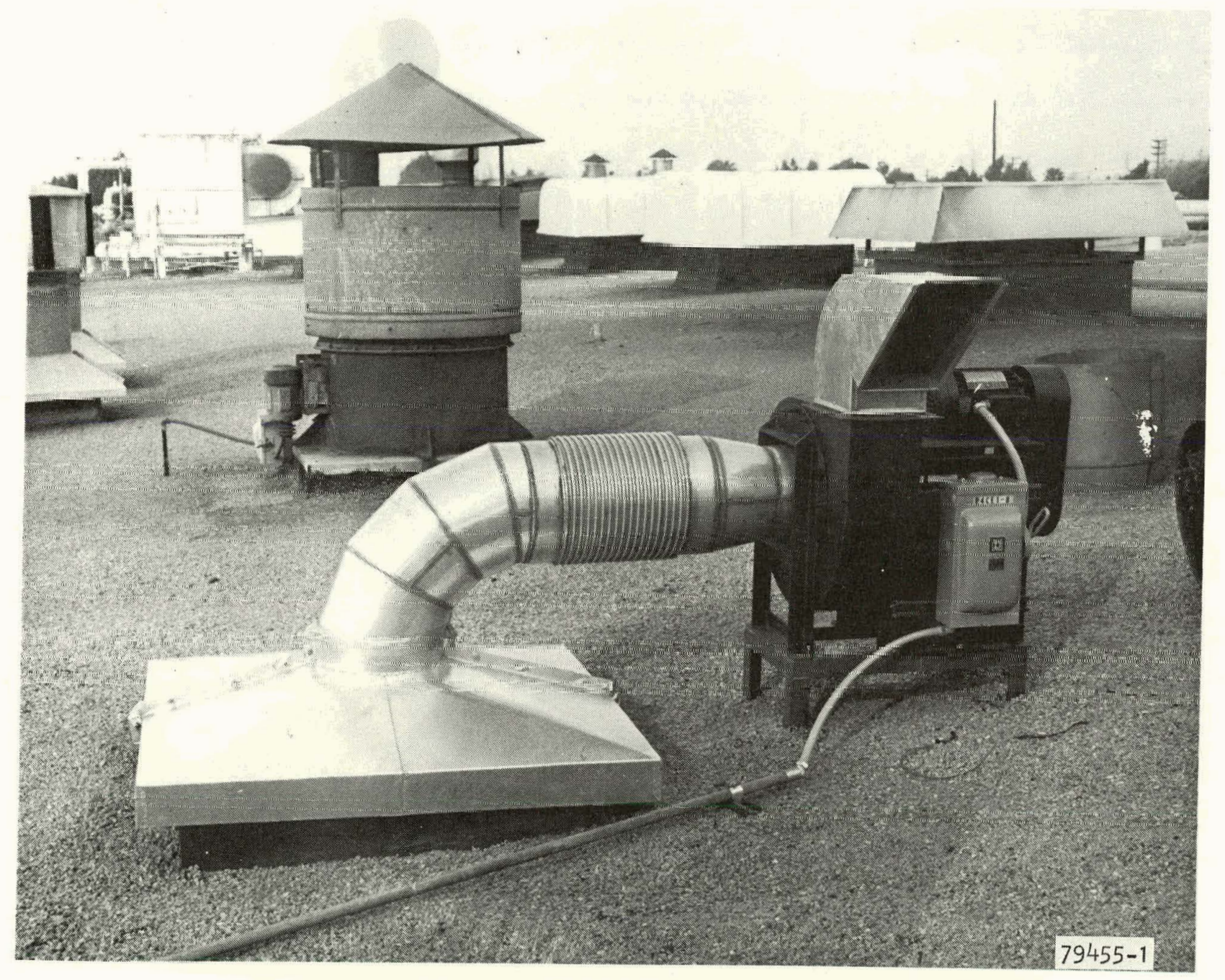

Figure 3-19. Roof Mounted Exhaust Fan 
SECTION 4

DEMONSTRATI ON PROGRAM

\section{TEST RATIONALE}

Important objectives of the program are (1) to determine that the plate-fin construction is durable and (2) to demonstrate that maintenance requirements are not excessive. Frequent inspection of the recuperator is not feasible; the practical alternative is to monitor heat transfer performance and flowstream pressure loss. A decrease in performance could indicate leakage, plugging or fin erosion. An increase in pressure loss could indicate plugging; and a decrease in pressure loss could indicate either leakage or fin erosion.

For a laboratory test, the standard procedure is to measure the flow rates and inlet and outlet pressures and temperatures in both streams. The heat gained by the cold stream is calculated as the product of flow rate, specific heat, and flow stream temperature increase. This is compared wi th the similarly calculated heat rejected by the hot stream; agreement within \pm 5 percent is the generally accepted criterion for a valid test.

In this installation, air leakage into the furnace is unknown and calculation of a heat balance requires installation of a flowmeter in the exhaust stream. This imposes undue penalty on the installation. Since the ultimate measure of system performance is reduction in fuel consumption, the heat balance is waived to eliminate the exhaust flow measurement.

\section{NSTRUMENTATI ON}

With the exception of exhaust gas flow, parameters discussed above are measured with typical laboratory instrumentation. Air flow and fuel flow are measured with orifice meters. Static pressures and recuperator pressure differentials are measured with distributed multiple sensors to provide readings which are representative of average conditions at the various locations. Temperatures are measured with the thermocouples; detail is shown in Table 4-1.

TABLE 4-1

THERMOCOUPLE DETAIL

Flow Stream, Location

Air, Recuperator inlet

Air, Recuperator outlet

Air, Burner

Gas, Furnace outlet

Gas, Recuperator inlet

Gas, Recuperator outlet

$\begin{array}{cc}\text { TC's, Total } & \text { TC's, Aspirating } \\ 2 & 0 \\ 3 & 1 \\ 2 & 0 \\ 5 & 1 \\ 5 & 1 \\ 5 & 1\end{array}$

TC's, Unshielded

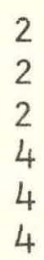


The aspirating thermocouples are shielded to minimize error due to local thermal radiation. In the gas stream, these readings are about $50^{\circ} \mathrm{F}$ higher than the average of the readings of the unshielded thermocouples. Data analysis is based on these readings.

0ther instrumentation and transducer detail is listed in Table 4-2. Locations of the items in Table 4-2 are shown pictorially in Figure 4-1. The instrumentation readout panel is shown in Figure 4-2.

\section{SAMPLE UNRECUPERATED DAILY FURNACE LOADING AND FUEL CONSUMPTION PROFILE}

Figure 4-3 shows a typical daily load/fuel consumption profile which was recorded prior to furnace recuperation. This was obtained at a time when the foundry was working two ten-hour shifts between 5 AM and 1 AM.

The 2900 CFH fuel consumption recorded at 11:30 AM on 6-8-77 represents 94 percent of furnace capacity. This is the only time during the 24-hour sample period that high-fire is maintained continuously for nearly two hours. For the rest of the period, fuel consumption averaged about 40 percent of capacity. Most of this reduced-heating operation corresponds to zero or minimal furnace loading; combustion is cyclic with the furnace alternating between high- and lowfire to replace heat-leak through the doors, stack, and structure. Since specific fuel consumption is calculated from melted tonnage, the furnace gets no credit for the "hold" portion of the daily cycle and specific fuel consumption is an inverse function of loading rate. It is apparent, then, that high-usage is the most efficient furnace operating scenario in terms of output per unit of energy consumption.

\section{CUMULATIVE LOAD/FUEL-CONSUMPTION PROFILES}

Figure 4-4 compares furnace performance for the year of recuperated operation with performance for an initial 168-day baseline period of unrecuperated operation. The corresponding load and fuel consumption data are listed in Table 4-3; comparing the total fuel consumptions at the end of 24 weeks:

$$
\text { Fuel savings }=4.7480-3.1753=1.5727 \mathrm{million} \text { cubic } \mathrm{ft}
$$

On a percentage basis,

$$
\text { Fuel savings }=((4.7480-3.1753) / 4.7480)(100)=33.1 \%
$$

However, the melted tonnage was greater for the period of unrecuperated operation. If fuel consumption were linearly proportional to load, the equivalent recuperated fuel consumption could be computed and the percent savings adjusted to yield a better appraisal of the effect of recuperation:

$$
\begin{aligned}
\text { Load-adjusted fuel consumption } & =(3.1753)(246.32 / 213.20) \\
& =3.6686 \mathrm{million} \text { cubic ft }
\end{aligned}
$$


TABLE 4-2

RECUPERATOR INSTRUMENTATION AND TRANSDUCER DETAIL

\begin{tabular}{|c|c|c|c|c|}
\hline I tem No. & Description & Range & Transducer & Comments \\
\hline 1 & gas flow meter & & Gas Co. furnished & \\
\hline 2 & gas inlet pressure & $0-10^{\prime \prime} \mathrm{H}_{2} \mathrm{O}$ & Bourns 5020 & pressure transmitter \\
\hline 3 & gas analyzer & & Gas Co. furnished & \\
\hline 4 & furnace out temperature & $2000^{\circ} \mathrm{F}$ & $\begin{array}{l}\text { Un ited Sensor } \\
\text { TL1-18-C/A-36F } \\
\text { asp irat ing probe } \\
+ \text { ( } 4 \text { req' } \text { d) Omega } \\
\text { \# CASS-14E-8 }\end{array}$ & $\begin{array}{l}\text { temperature readout } \\
5 \text { channels }\end{array}$ \\
\hline 5 & furnace out pressure & $0-10^{\prime \prime} \mathrm{H}_{2} \mathrm{O}$ & Bourns 5020 & pressure transmitter \\
\hline 6 & recuperator inlet temperature & $1500^{\circ} \mathrm{F}$ & $\begin{array}{l}\text { United Sensor } \\
\text { TL1-18-C/A-36F } \\
\text { aspirat ing probe } \\
+\left(4 \mathrm{req}^{\prime} \mathrm{d}\right) \text { Omega } \\
\text { \# CASS }-14 \mathrm{E}-8\end{array}$ & $\begin{array}{l}\text { temperature readout } \\
5 \text { channels }\end{array}$ \\
\hline 7 & recuperator outlet temperature & $300-400^{\circ} \mathrm{F}$ & $\begin{array}{l}4 \text { required Omega } \\
\text { \# CASS }-14 \mathrm{E}-8\end{array}$ & $\begin{array}{l}\text { temperature readout } \\
4 \text { channels }\end{array}$ \\
\hline 8 & recuperator inlet pressure & $0-10^{11} \mathrm{H}_{2} \mathrm{O}$ & Bourns 5020 & pressure transmitter \\
\hline 9 & recuperator outlet pressure & $\mathrm{O}-10^{\prime \prime} \mathrm{H}_{2} \mathrm{O}$ & Bourns 5020 & pressure transmitter \\
\hline 10 & combustion analyzer & & Gas Co. furnished & \\
\hline 11 & $\begin{array}{l}\text { time and date } \\
\text { ambient air humidity }\end{array}$ & & & $\begin{array}{l}\text { Write } \\
\text { read manually }\end{array}$ \\
\hline 12 & pressure air side in & $30-35^{\prime \prime} \mathrm{H}_{2} \mathrm{O}$ & Bourns 5020 & pressure transmitter \\
\hline 13 & temperature air side in & $100-150^{\circ} \mathrm{F}$ & $\begin{array}{l}\text { Omega \# CASS }-14 E-8 \\
\text { (2 required) }\end{array}$ & $\begin{array}{l}\text { temperature readout } \\
2 \text { channels }\end{array}$ \\
\hline 14 & pressure air side out & $0-30^{\prime \prime} \mathrm{H}_{2} \mathrm{O}$ & Bourns 5020 & pressure transmitter \\
\hline 15 & temperature air side out & $1500^{\circ} \mathrm{F}$ & $\begin{array}{l}\text { United Sensor } \\
\text { TL1-18-C/A-36F } \\
\text { asp irat ing probe } \\
\text { Omega \# CASS-14E-8 } \\
\text { ( } 2 \text { required) }\end{array}$ & $\begin{array}{l}\text { temperature readout } \\
3 \text { channels }\end{array}$ \\
\hline 16 & furnace bath temperature (charge) & $1500^{\circ} \mathrm{F}$ & & installed \\
\hline 17 & combustion blower & on-off & indicator 1 ight & \\
\hline 18 & stack blower & on-off & indicator 1 ight & \\
\hline
\end{tabular}


NUMBERS DENOTE I TEMS

IN TABLE $4-2$

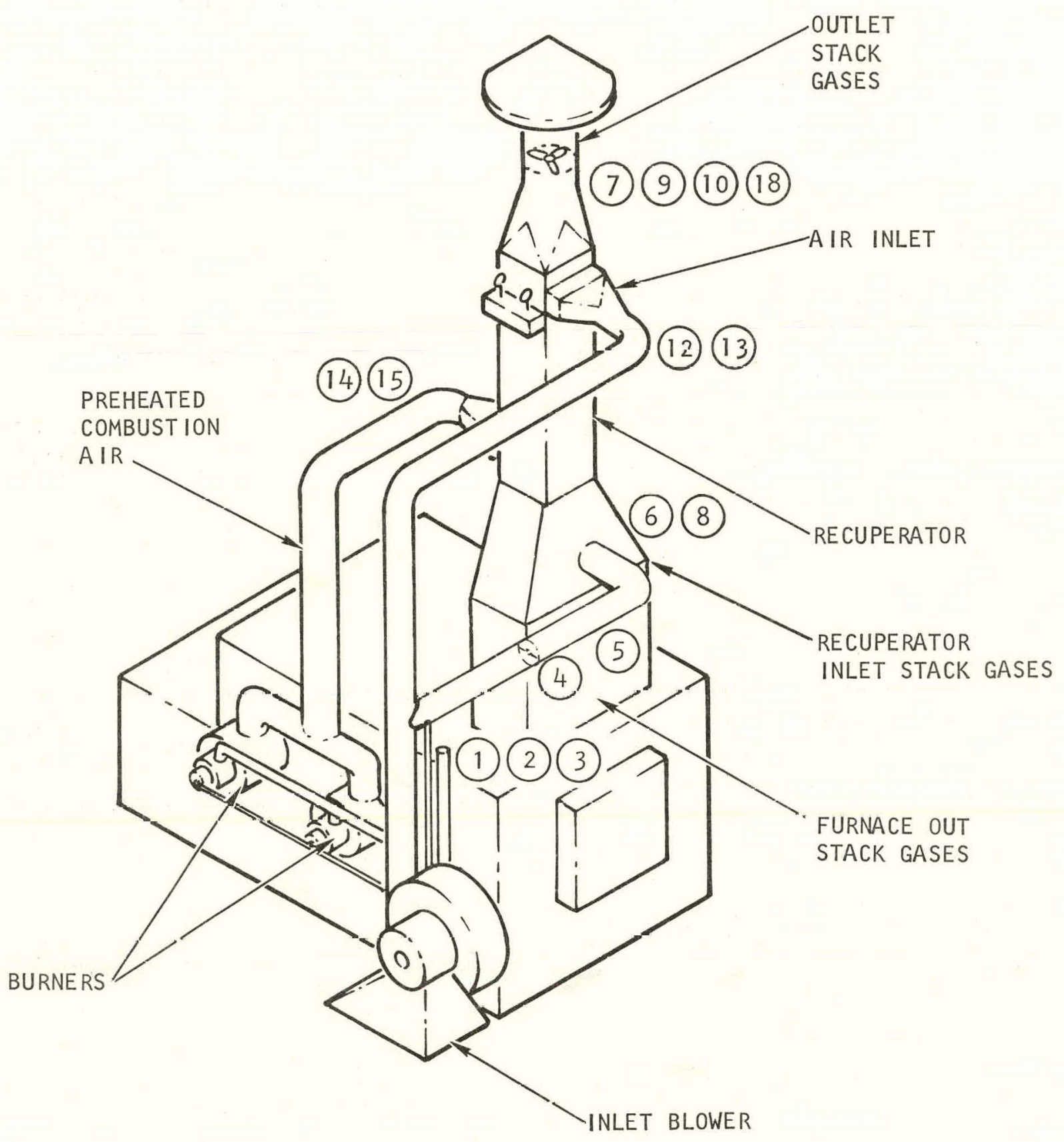

S-19585-A

Figure 4-1. McGowan Alumi num Remelt Furnace Recuperator System Instrumentation 


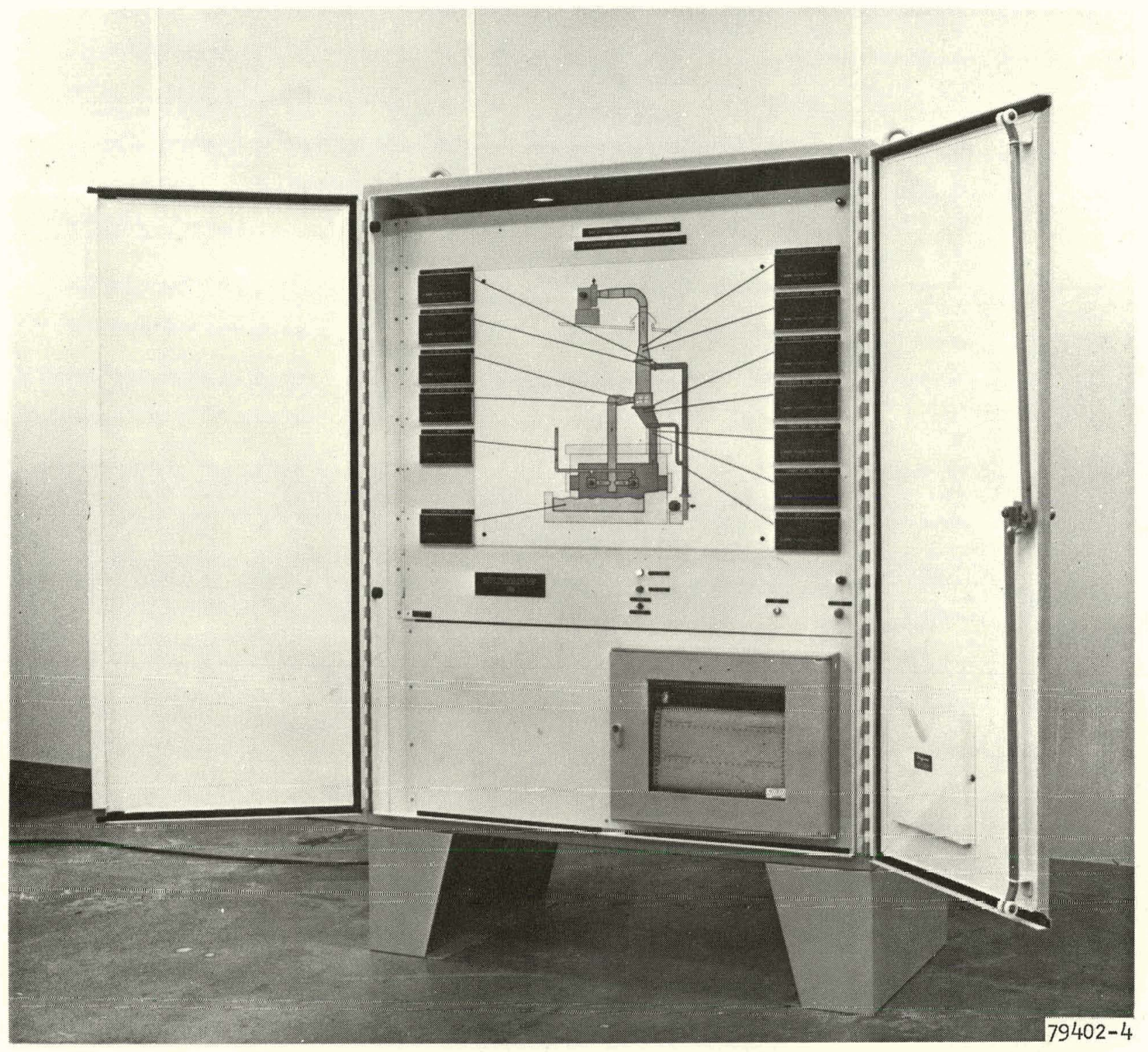

Figure 4-2. Instrumentation Panel 


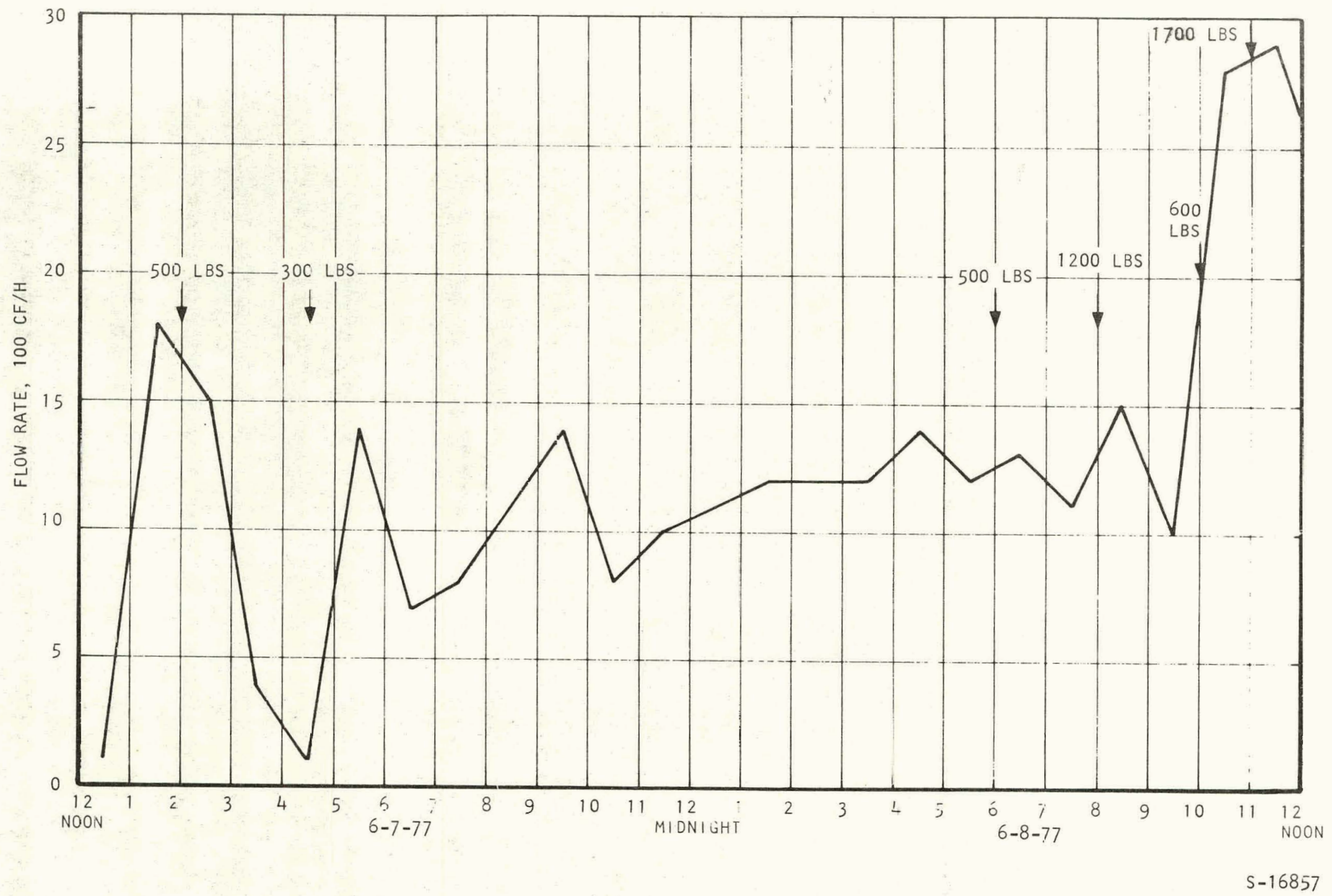

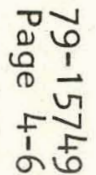

Figure 4-3. McGowar Furnace Load/Fuel-Consumption Profile; Random 24-Hour Period Prior to Recuperation 


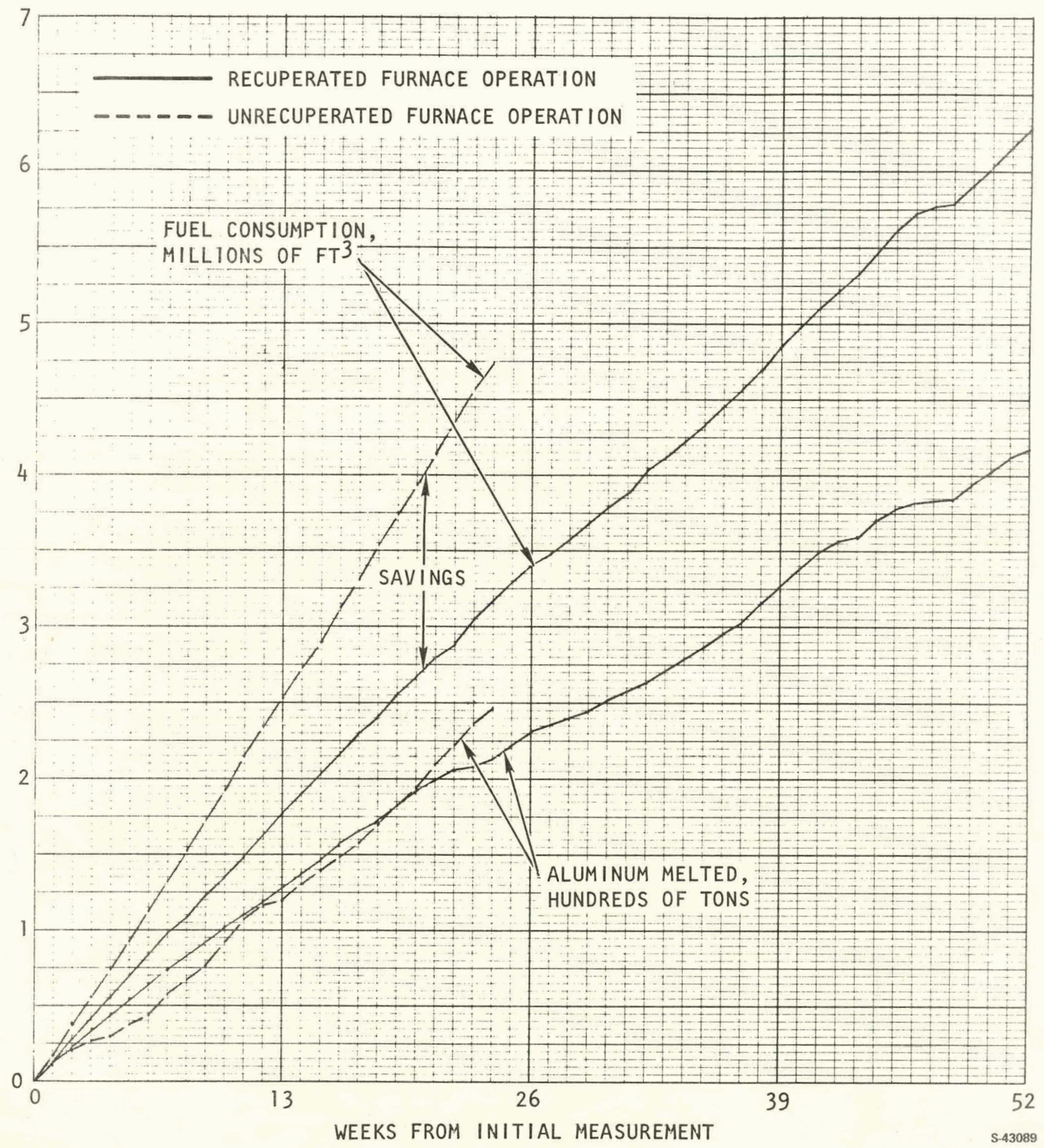

Figure 4-4. McGowan Furnace Cumulative Load and Fuel Consumption Profiles 
TABLE $4-3$

MCGOWAN FURNACE LOAD AND FUEL CONSUMPTION DATA

\begin{tabular}{|c|c|c|c|c|c|c|c|c|}
\hline \multirow{3}{*}{$\begin{array}{c}\begin{array}{c}\text { Mode of } \\
\text { Furnace } \\
\text { Operation }\end{array} \\
\begin{array}{c}\text { Weeks From } \\
\text { Initial } \\
\text { Measurement }\end{array}\end{array}$} & \multicolumn{4}{|c|}{ Unrecuperated } & \multicolumn{4}{|c|}{ Recuperated } \\
\hline & \multicolumn{2}{|c|}{ Totals for Week } & \multicolumn{2}{|c|}{ Cumulative } & \multicolumn{2}{|c|}{ Totals for Week } & \multicolumn{2}{|c|}{ Cumulative } \\
\hline & $\begin{array}{l}\text { Melt, } \\
\text { Tons }\end{array}$ & $\begin{array}{c}\text { Fuel } \\
\text { Consumption, } \\
10^{6} \mathrm{ft}^{3}\end{array}$ & $\begin{array}{l}\text { Melt } \\
\text { Tons }\end{array}$ & $\begin{array}{c}\text { Fue } 1 \\
\text { Consumption, } \\
10^{6} \mathrm{ft}^{3}\end{array}$ & $\begin{array}{l}\text { Melt, } \\
\text { Tons }\end{array}$ & $\begin{array}{c}\text { Fuel } \\
\text { Consumption, } \\
10^{6} \mathrm{ft}^{3}\end{array}$ & $\begin{array}{l}\text { Melte, } \\
\text { Tons }\end{array}$ & $\begin{array}{c}\text { Fuel } \\
\text { Consumption, } \\
10^{6} \mathrm{ft}^{3}\end{array}$ \\
\hline 1 & 12.44 & 0.1738 & 12.44 & 0.1738 & 10.72 & 0.1306 & 10.72 & 0.1306 \\
\hline 2 & 7.58 & 0.1938 & 20.02 & 0.3676 & 11.15 & 0.1528 & 21.87 & 0.2834 \\
\hline 3 & 5.55 & 0.1844 & 25.57 & 0.5520 & 12.36 & 0.1305 & 34.23 & 0.4139 \\
\hline 4 & 3.90 & 0.1815 & 29.47 & 0.7335 & 9.63 & 0.1380 & 43.86 & 0.5519 \\
\hline 5 & 7.44 & 0.1991 & 36.91 & 0.9326 & 9.87 & 0.1481 & 53.73 & 0.7000 \\
\hline 6 & 6.63 & 0.1853 & 43.54 & 1.1179 & 10.31 & 0.1413 & 64.04 & 0.8413 \\
\hline 7 & 13.06 & 0.2035 & 56.60 & 1.3214 & 10.19 & 0.1380 & 74.23 & 0.9793 \\
\hline 8 & 10.25 & 0.2009 & 66.85 & 1.5523 & 7.95 & 0.1139 & 82.18 & 1.0932 \\
\hline 9 & 8.23 & 0.1920 & 75.08 & 1.7143 & 9.97 & 0.1361 & 92.15 & 1.2293 \\
\hline 10 & 17.55 & 0.2203 & 92.63 & 1.9346 & 9.36 & 0.1209 & 101.51 & 1.3502 \\
\hline 11 & 14.93 & 0.2188 & 107.56 & 2.1534 & 8.79 & 0.1460 & 110.30 & 1.4962 \\
\hline 12 & 8.42 & 0.1912 & 115.98 & 2.3446 & 8.31 & 0.1373 & 118.61 & 1.6335 \\
\hline 13 & 3.24 & 0.1806 & 119.22 & 2.5252 & 11.24 & 0.1377 & 129.85 & 1.7712 \\
\hline 14 & 11.25 & 0.1983 & 130.47 & 2.7235 & 8.03 & 0.1310 & 173.88 & 1.9022 \\
\hline 15 & 9.05 & 0.1728 & 139.52 & 2.8963 & 9.01 & 0.1346 & 146.89 & 2.0368 \\
\hline 16 & 9.39 & 0.2252 & 148.91 & 3.1215 & 10.85 & 0.1373 & 157.74 & 2.1741 \\
\hline 17 & 8.60 & 0.1877 & 157.51 & 3.3092 & 7.81 & 0.1314 & 165.55 & 2.3055 \\
\hline 18 & 12.05 & 0.2241 & 169.56 & 3.5333 & 5.49 & 0.1046 & 171.04 & 2.4101 \\
\hline 19 & 12.82 & 0.2125 & 182.38 & 3.7458 & 12.44 & 0.1481 & 183.48 & 2.5582 \\
\hline 20 & 12.01 & 0.1937 & 194.39 & 3.9395 & 8.25 & 0.1173 & 191.73 & 2.6755 \\
\hline 21 & 14.89 & 0.2068 & 209.28 & 4.1463 & 7.85 & 0.1225 & 199.58 & 2.7980 \\
\hline 22 & 13.10 & 0.2158 & 222.38 & 4.3621 & 6.14 & 0.0845 & 205.72 & 2.8825 \\
\hline 23 & 13.50 & 0.1995 & 235.88 & 4.5616 & 2.03 & 0.1657 & 207.75 & 3.0482 \\
\hline 24 & in hit & ก $186 h$ & $21663 ?$ & 4 7than & $E$ th & ויו & 21370 & 31,753 \\
\hline 25 & & & & & 7.61 & 0.1250 & 220.81 & 3.3003 \\
\hline 26 & & & & & $y .10$ & $0.10 / 2$ & 230.51 & $3.40 / 5$ \\
\hline 27 & & & & & 4.90 & 0.0695 & 23541 & 3.4770 \\
\hline 28 & & & & & 4.16 & 0.1069 & 239.57 & 3.5839 \\
\hline 29 & & & & & 4.66 & 0.1025 & 244.23 & 3.6864 \\
\hline 30 & & & & & 6.86 & 0.1080 & 251.09 & 3.7944 \\
\hline 31 & & & & & 6.52 & 0.1051 & 257.61 & 3.8995 \\
\hline 32 & & & & & 5.58 & 0.1440 & 263.19 & 4.0435 \\
\hline 33 & & & & & 6.28 & 0.0725 & 269.47 & 4.1160 \\
\hline 34 & & & & & 9.41 & 0.1191 & 278.88 & 4.2351 \\
\hline 35 & & & & & 6.99 & 0.1005 & 285.87 & 1.3356 \\
\hline 36 & & & & & 9.37 & 0.1209 & 295.24 & 4.4565 \\
\hline 37 & & & & & 7.52 & 0.1115 & 302.76 & 4.5680 \\
\hline 38 & & & & & 12.53 & 0.1266 & 315.29 & 4.6946 \\
\hline 39 & & & & & 11.83 & 0.1649 & 327.12 & 4.8595 \\
\hline 40 & & & & & 11.72 & 0.1248 & 338.84 & 4.9843 \\
\hline 41 & & & & & 10.36 & 0.1160 & 349.20 & 5.1003 \\
\hline 42 & & & & & 7.10 & 0.1160 & 356.30 & 3.2163 \\
\hline 43 & & & & & 2.68 & 0.1209 & 358.98 & 5.3372 \\
\hline 44 & & & & & 12.04 & 0.1382 & 371.02 & 5.4754 \\
\hline 45 & & & & & 7.25 & 0.1340 & 378.27 & 5.6094 \\
\hline 46 & & & & & 3.23 & 0.1186 & 381.50 & 5.7280 \\
\hline 47 & & & & & 2.00 & 0.0378 & 383.50 & 5.7658 \\
\hline 48 & & & & & 0.88 & 0.0169 & 384.38 & 5.7827 \\
\hline 49 & & & & & 9.66 & 0.1231 & 394.04 & 5.9058 \\
\hline 50 & & & & & 7.87 & 0.1259 & 401.91 & 6.0317 \\
\hline 51 & & & & & 9.56 & 0.1239 & 411.47 & 6.1556 \\
\hline 52 & & & & & 4.87 & 0.1290 & 416.34 & 6.2846 \\
\hline
\end{tabular}


As noted above in the discussion of the sample daily cycle, specific fuel consumption is an inverse function of furnace usage. Therefore, the assumption that total fuel consumption is linearly proportional to total load is valid for comparison purposes only when the unrecuperated and recuperated loading profiles are identical. In this instance, the recuperated tonnage is lower and recuperated operation represents less efficient furnace utilization.

Both of the above fuel savings calculations are approximations which can be misleading. A higher degree of refinement is imperative to the accurate evaluation of the effect of recuperation; the recommended method of analysis is explained under ENERGY SAVINGS THROUGH RECUPERATION.

\section{DAILY LOAD/ENERGY-CONSUMPTION DATA CORRELATION}

To generate an unrecuperated data base for the evaluation of the recuperated system, furnace loading and energy consumption data were recorded on a daily basis from June 7 through November 22, 1977. During this period, the daily load varied from a few hundred pounds to several tons, depending on the foundry pouring schedule. For each day, the specific energy consumption was computed and plotted as a function of load. After 168 days of data acquisition, regression analysis was employed to correlate specific energy consumption as a function of daily melting rate. The correlation curve is an exponential of the form

$$
y=a e^{b x}+c
$$

where:

$$
\begin{aligned}
& y=\text { Specific cnergy consumption, millions of BTU per ton melted } \\
& x=\text { Daily aluminum melt rate, tons per } 24 \text { hour period }
\end{aligned}
$$

The regression analysis determined values of 48.93 and -0.78 for the coefficient (a) and the exponent (b), respectively. The constant (c) is assumed to be 6.0 $\times 10^{6} \mathrm{BTU} / \mathrm{ton}$, based on the furnace rating of 0.5 ton/hr capacity at $3.0 \times 10^{6}$ $\mathrm{BTU} / \mathrm{hr}$ firing rate. The coefficient of determination $\left(r^{2}\right)$ is 0.93 which indicates a good data fit. The unrecuperated baseline specific-energy-consumption/ load relationship, then, is defined by the equation

$$
\text { USEC }-48.93 e^{-0.78 M}+6.0
$$

where:

$$
\begin{aligned}
\text { USEC } & =\text { Unrecuperated specific energy consumption, } 10^{6} \mathrm{BTU} / \text { ton } \\
M & =\text { Daily melting rate, tons per } 24 \text { hour period }
\end{aligned}
$$

A similar data correlation procedure was followed after recuperation, but the value of $(\mathrm{c})$ is reduced to $4.0 \times 10^{6} \mathrm{BTU} /$ ton to reflect the energy savings predicted by the thermal analysis of Appendix A. Based on the entire year of 
furnace operation, the recuperated specific-energy-consumption/load relationship is defined by the equation

$$
\operatorname{RSEC}=39.73 \mathrm{e}^{-0.92 M}+4.0
$$

where:

$$
\text { RSEC = Recuperated specific energy consumption, } 10^{6} \mathrm{BTU} / \mathrm{ton}
$$

The data were correlated on a cumulative basis at the end of each quarter; the evolution of the correlation parameters is shown in Table 4-4. The bottom of Table 4-4 compares the specific energy consumptions calculated from each of the four correlation equations over a load rate range of one to four tons per day. The ratios of maximum to minimum values are as follows:

$$
\begin{array}{ccccc}
\text { Melting rate, tons/day } & 1 & 2 & 3 & 4 \\
\text { (Max RSEC)/(Min RSEC) } & 1.032 & 1.055 & 1.084 & 1.072
\end{array}
$$

The consistency shown above is rather remarkable, particularly when one considers that several air flow adjustments and one fuel flow adjustment were implemented over the year. The clear indication is that there has been no performance deterioration; if there is any trend, it is that specific energy consumption has decreased slightly over the year.

The equations for recuperated and unrecuperated furnace energy consumption are plotted in Figure 4-5. For any daily melting rate, recuperated and unrecuperated furnace operation are equivalent and the fuel savings attributable to recuperation is represented by the difference between the curves. On a percentage basis, the savings is

$$
\text { Percent fuel savings }=((\text { USEC }- \text { RSEC }) / \text { USEC })(100)
$$

It is observed in Figure 4-5 that savings varies with furnace melting rate. Consequently, a precise evaluation requires a numerical integration of the daily savings throughout the year. This is laborious, however, and, as the variation in percent savings with melting rate is not great, a satisfactory approximation can be based on average melting rate.

As shown in Figure 4-6, the exponential form of the specific-energyconsumption equation provides an excellent correlation with a graphical data interpretation for melting rates in excess of 1 ton per day. At lower melting rates, the curves diverge and the statistical equation is 18 percent optimistic at a melting rate of 0.5 ton per day. When carried to the intercept, the equation has no meaning because SFC must necessarily approach infinity asymptotically as fuel is consumed to replenish the furnace heat losses. Therefore, the rationale for the selection of the exponential curve fits is that (1) they provide the best data correlation for melting rates in excess of 1 ton per day ( 8 percent of capacity), and (2) melting rates lower than 1 ton per day are deemed insignificant. 
TABLE $4-4$

EFFECT OF CALENDAR TIME ON SPECIFIC ENERGY CONSUMPTION CORRELATION AND DETERMINATI ON COEFFICIENTS: RECUPERATED OPERATION

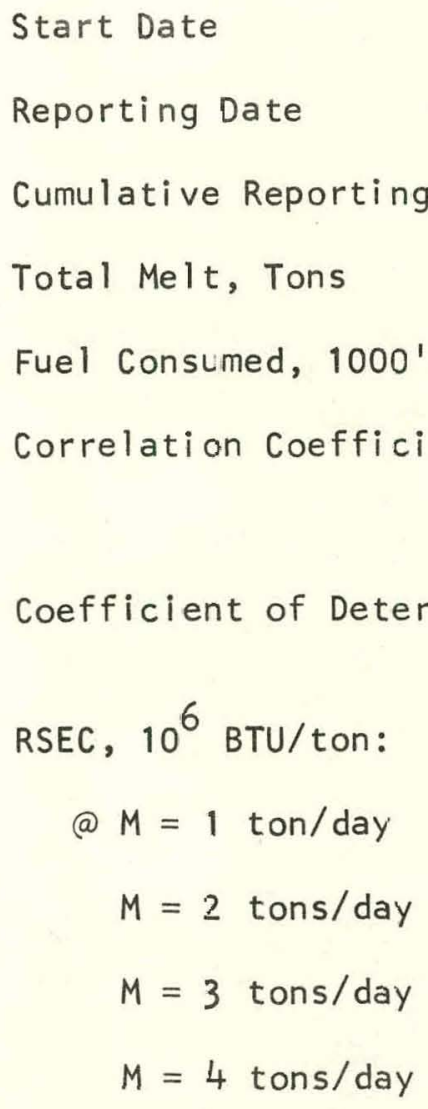

$\begin{array}{llll}2-1-78 & 2-1-78 & 2-1-78 & 2-1-78 \\ 4-30-78 & 7-30-78 & 10-30-78 & 1-31-79 \\ 13 & 26 & 39 & 52 \\ 120.85 & 230.51 & 327.12 & 416.34 \\ 1545 & 3423 & 4856 & 6436 \\ 34.79 & 34.55 & 36.49 & 39.73 \\ -0.81 & -0.82 & -0.87 & -0.92 \\ 0.91 & 0.89 & 0.79 & 0.77\end{array}$

$\begin{array}{llll}19.48 & 19.22 & 19.29 & 19.83 \\ 10.88 & 10.70 & 10.40 & 10.31 \\ 7.06 & 6.95 & 6.68 & 6.51 \\ 5.36 & 5.30 & 5.12 & 5.00\end{array}$




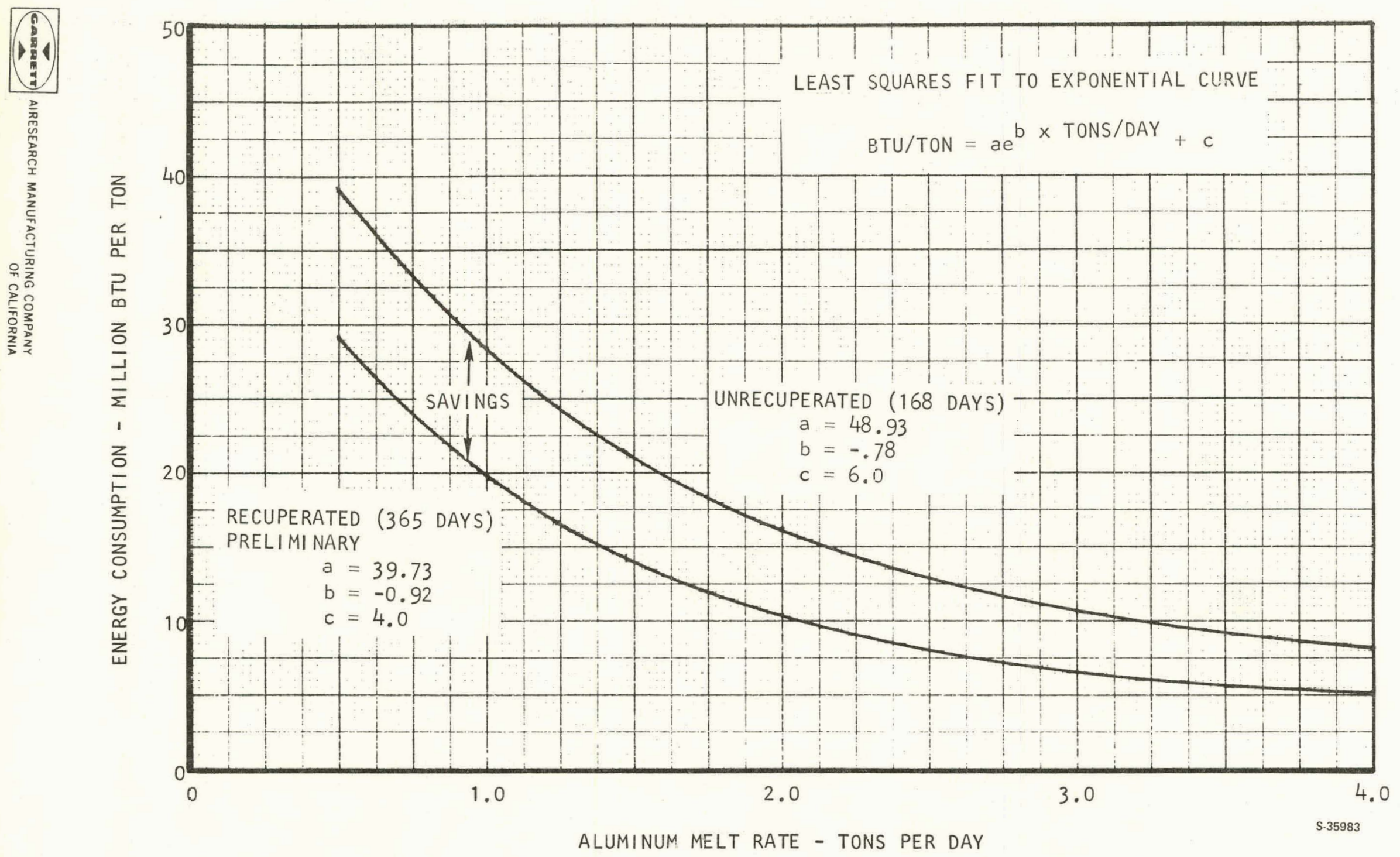

Figure 4-5. Effect of Daily Melting Rate on McGowan Furnace Specific Energy Consumption: Recuperated vs Unrecuperated Furnace Operation 


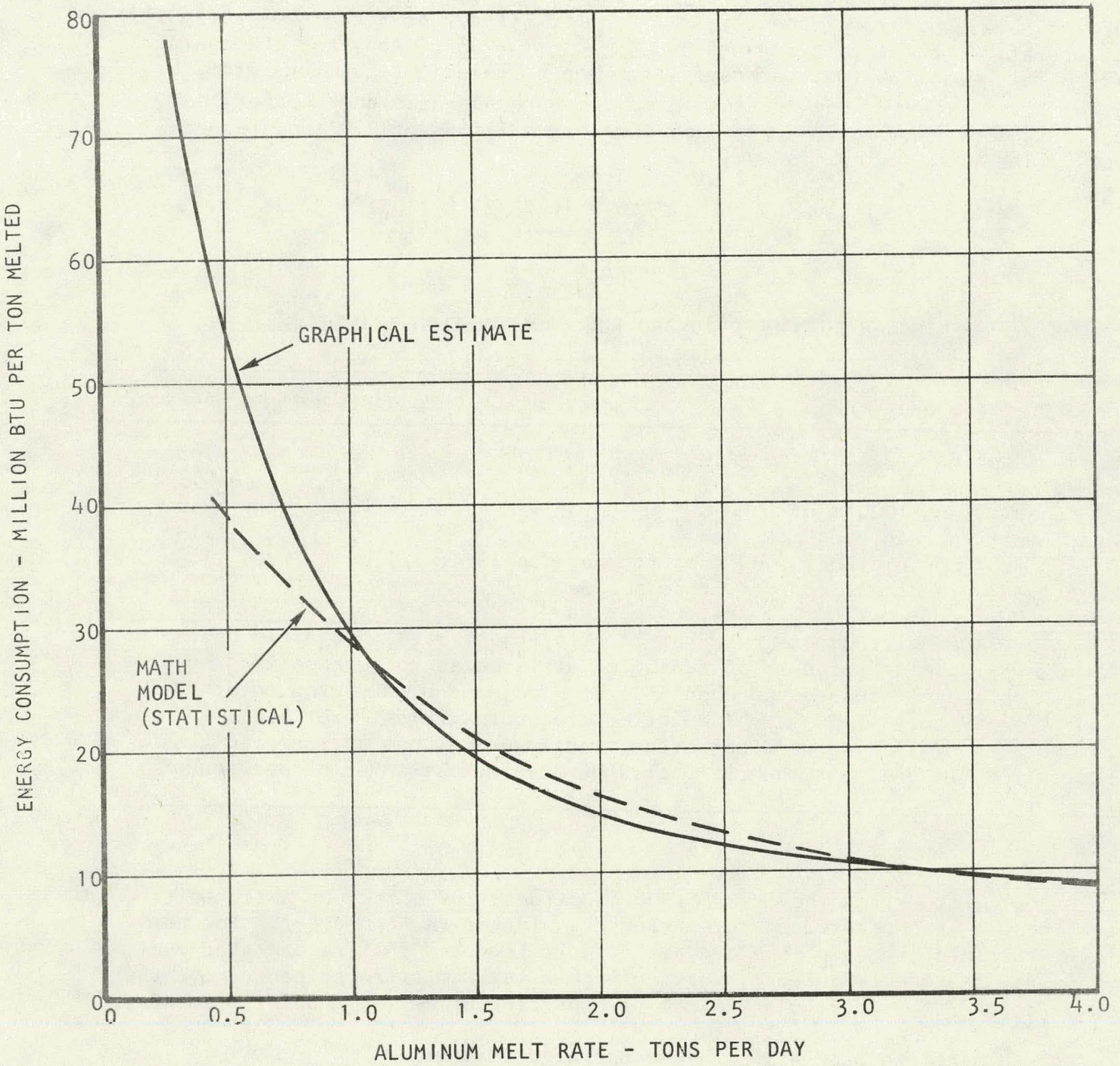

S-23091-A

Figure 4-6. Unrecuperated Specific Energy Consumption of McGowan Furnace 


\section{ENERGY SAVINGS THROUGH RECUPERATI ON}

\section{Operating Experience}

Furnace total load and total fuel consumption data are shown in Table 4-5. The average daily melting rates for unrecuperated and recuperated operation are 1.47 and 1.14 tons/day, respectively. For the 533-day period of monitored furnace operation, the total load was $246.3+416.3=662.6$ tons and the average melting rate was 1.24 tons per day. From the correlation equations or Figure 4-5, at a 1.24 ton-per-day melting rate, the unrecuperated and recuperated specific energy consumptions are 24.6 and $16.7 \mathrm{millions}$ of BTU/ton, respectively. The true savings is

$$
\text { Percent fuel savings }=((24.6-16.7) / 24.6)(100)=32.1 \%
$$

TABLE 4-5

MCGOWAN FURNACE LOAD AND FUEL CONSUMPTION SUMMARY

Mode of furnace operation

Number of consecutive calendar days

Tons melted

Fuel consumption, $1000^{\prime} \mathrm{s}$ of $\mathrm{ft}^{3}$

Average melting rate, tons per day

Specific fuel consumption, $1000^{\prime} \mathrm{s}$ of $\mathrm{ft}^{3}$ per ton (SFC) $* 21.8$

Cumulative average melting rate, tons per day $(U+R)$

Specific fuel consumption @ 1.24 tons per day

*SFC at average melting rate based on correlation of data on

This prociture daily basis

(Fiqure 4-5). This procedure accounts for differemces ill furnace loading profiles which are not considered when SFC is calculated by dividing Luldi ruel consumption by total tonnage. The latter procedure yields lower SFC's for both unrecuperated and recuperated operation, and lower savings as the result of recuperation; it does not, however, provide a valid basis for comparison of SFC's.

As calculated from the correlation equations, the effect of daily melting rate (load) on recuperated energy savings is plotted in Figure 4-7. For daily melting rates in excess of one ton per day, it is noted that recuperaled fuel savings is reasonably uniform, varying from a maximum of 22 percent above the mean value at 3 tons/day to a minimum of 6 percent below the mean at 1 ton/day.

As explained on page 4-10, the recuperated savings is

$$
S(\%)=((\text { USEC }- \text { RSEC }) / \text { USEC })(100) \text {. }
$$

Figure 4-7 was derived from Figure $4-5$ by applying this equation to curve values at several melting rates. Since the SFC curves are empirical data interpretations, the peak in Figure 4-7 may represent a statistical anomaly without any 


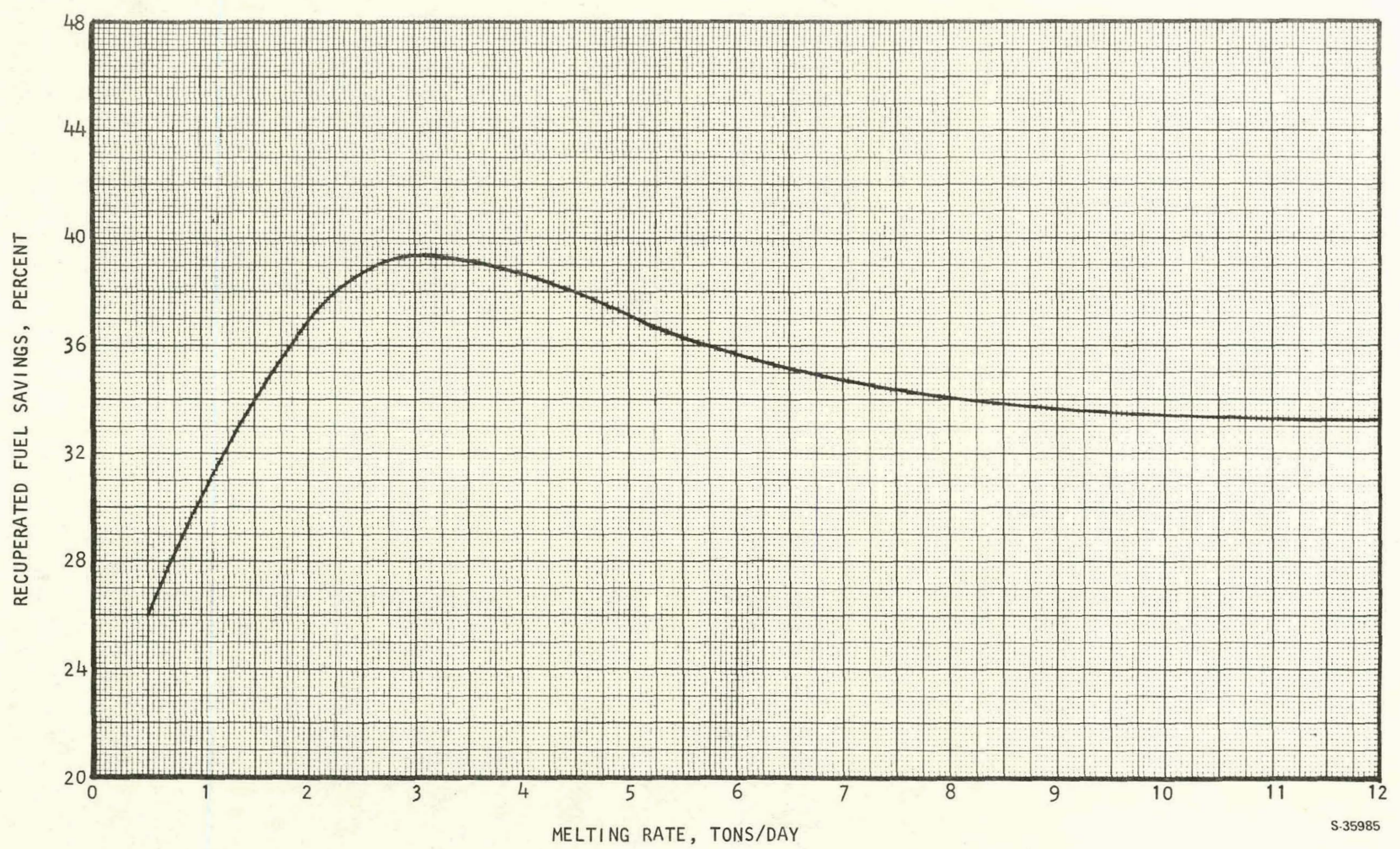

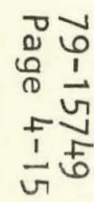

Figure 4-7. Effect of Daily Melting Rate on Recuperated Fuel Savings 
thermodynamic significance. The conclusion to be drawn from Figure 4-7 is that fuel savings is reasonably uniform over a wide range of melting rates. This suggests that, although furnace loading varies significantly around the clock and around the calendar, fairly accurate fuel savings projections can be based on transient conditions near the top of the high-fire cycle. This fact has significance beyond the subject project; it is probable that the near-constant savings premise holds for any cyclic melting furnace.

Although the recuperator target effectiveness is 85 percent, the unit was designed for 91 percent to provide a margin against possible gradual impairment which might be caused by fouling or minor leakage. At this writing no problems have developed and typical recorded effectiveness is slightly above 91 percent. However, the measured heat recovery corresponds to that predicted for 85 percent recuperator effectiveness; the discrepancy is attributable to $100^{\circ} \mathrm{F}$ of preheat which is lost by convection and radiation from the transition duct which rarries the preheated combustion air to the burners. This loss amounts to 8 percent of the heat recovered or 2.5 percent of the unrecuperated furnace fuel consumption. Addition of more duct insulation would reduce this loss and further decrease fuel consumption, but the burner may be incapable of accommodating the higher air temperature.

\section{Theoretical Predictions}

The system thermal analysis (Appendix A) predicted the following percentage distribution of heat under unrecuperated baseline furnace operation per Condition 2 of Table A-1:

$$
\begin{aligned}
& \text { 1. Sharge melting } \quad 18.0 \\
& \text { 2. Furnace losses } 29.0 \\
& \text { 3. Stack loss } 53.0 \\
& 100.0
\end{aligned}
$$

Unless the distribution of heat within the system is changed, the recuperator can operate on only 53 percent of the energy consumption. In accordance with the Second Law of Thermodynamics, a portion of the stack energy becomes unrecoverable if the exhaust is diluted to lower its temperature in the interest of protecting the recuperator. On the basis of (1) a $1550^{\circ} \mathrm{F}$ maximum allowable exhaust recuperator inlet temperature, (2) a $1928^{\circ} \mathrm{F}$ undiluted exhaust temperature per analysis Condition 2 , and (3) a $100^{\circ} \mathrm{F}$ air recuperator inlet temperature, the percentage of stack energy which is thermodynamically recoverable is:

$$
\left.E_{S A}=(1550-100) /(1928-100)\right)(100)=79.3 \%
$$

where $E_{S A}=$ Percentage of stack energy available 
Expressed as a percentage of total energy input to the furnace, the recoverable energy is:

$$
E_{T A}=(0.793)(0.53)(100)=42.0 \%
$$

where $E_{T A}=$ Percentage of total furnace energy available

The heat capacity of the exhaust stream prior to dilution exceeds that of the combustion air stream by virtue of (1) higher flow rate due to the fuel addition, and (2) higher specific heat capacity due to chemical composition difference and higher average temperature. From the analysis at Condition 2, the flow stream capacity ratio is:

$$
C /{ }_{A} / C_{G}=W_{A} C_{P A} / W_{G} C_{P G}=(2270)(0.254) /(2396)(0.283)=0.850
$$

where:

$$
\begin{aligned}
& C_{A}=\text { Combustion air heat capacity, } B T U / m i n-{ }^{\circ} \mathrm{F} \\
& C_{G}=\text { Undiluted exhaust gas heat capacity, BTU/min- }{ }^{\circ} \mathrm{F} \\
& W_{A}=\text { Combustion air flow rate, } \mathrm{lb} / \mathrm{min} \\
& C_{P A}=\text { Combustion air specific heat at constant pressure, } \mathrm{BTU} / \mathrm{Ib}-{ }^{\circ} \mathrm{F} \\
& W_{G}=\text { Undiluted exhaust gas flow rate, lb/min } \\
& C_{P G}=\text { Undiluted exhaust gas specific heat at constant pressure, } \mathrm{BTU} / \mathrm{Ib}-{ }^{\circ} \mathrm{F}
\end{aligned}
$$

For a recuperator of airside effectiveness $\varepsilon_{A}=85$ percent, the percentage of total energy recovered by recuperation is:

$$
E_{R}=100 E_{T A} \epsilon_{A} C_{A} / C_{G}=(100)(0.42)(0.85)(0.85)=30.3 \%
$$

where:

$$
\begin{aligned}
& E_{R}= \text { Percentage of total furnace energy recovered } \\
&{ }_{A}=\text { Recuperator air heating effectiveness, dimensionless } \\
&{ }^{E_{A}}=\left(T_{2 A}-T_{1 A}\right) /\left(T_{1 G}-T_{1 A}\right) \\
& T_{1 A}=\text { Recuperator air inlet temperature } \\
& T_{2 A}=\text { Recuperator air outlet temperature } \\
& T_{1 G}=\text { Recuperator exhaust gas inlet temperature }
\end{aligned}
$$


The above is comparable to a 32.9 percent fuel savings predicted by the analysis of Appendix A. The difference between these analytical predictions is due to the fact that the undiluted exhaust temperatures differ for Conditions 2 and 4. In the latter case, the furnace is operated stoichiometrically and the calculated undiluted exhaust temperature is only $1791^{\circ} \mathrm{F}$. In this case, the dilution loss is smaller and there is agreement between the analyses:

$$
\begin{aligned}
E_{S A} & =((1550-100) /(1791-100)(100)=85.7 \% \\
E_{T A} & =(0.857)(0.53)(100)=45.4 \% \\
E_{R} & =(100)(0.454)(0.85)(0.85)=32.8 \%
\end{aligned}
$$

The above analysis emphasizes the importance in waste heat recovery of high effectiveness, (2) high temperature capability, (3) precise combustion tuning, and (4) thorough furnace insulation. The point is that, typically, much of the wasted energy is thermodynamically unaval lable atid therefore any recuvery effort should be on a systems basis.

With some simplifying assumptions, recuperated fuel savings can be expressed in terms of the air preheat temperature, the exhaust gas recuperator inlet. temperature, the air/fuel flow ratio, and physical properties. This relationship is derived in Appendix $C$.

Using the recommended Equation (2C) at Condition 4 of the Appendix $A$ analysis, the percent fuel savings realized through recuperation is:

$S^{\prime}=\left[1-\frac{21,520-(18.24)(0.283)(1550-100)}{21,250+(17.24)(0.254)(1332-100)-(18.24)(0.283)(1550-100)}\right][100]=27.8 \%$

The most significant of the assumptions in the derivation is that the furnace exhaust temperature is the same for recuperated and unrecuperated furnace operation. The therilal analysis of Appendix $A$ and the furnace test data both indicate that this is at least a reasonable approximation.

Typical recuperated furnace high-fire data were recorded near the top of the heating cycle in Run 5-3 on August 1, 1978. Applying, the fuel savings Equation (2C) from Appendix $C$ to the data from Run 5-3 as summarized in Table 4-6:

$S^{\prime}=\left[1-\frac{21,210-(21.75)(0.288)(1572-119)}{21,210+(20.75)(0.256)(1336-119)-(21.75)(0.288)(1572-119)}\right][100]=34.8 \%$

The furnace load for August 1, 1978 was only 0.923 ton and the recuperated energy savings calculated from the data correlation was 29.6 percent; the deviation of Equation (2C) from the correlation is +17.6 percent. If, however, the rate of savings as calculated from Equation $(2 C)$ is compared to the savings representative of the 533 -day period, the deviation is only +8.4 percent. Although Equation (2C) does not account for the furnace load profile and therefore can be misleading when applied to a specific daily condition, it appears to provide a reasonable approximation of the fuel savings realized over a longer period of more representative furnace loading. It follows that Equation (2C) is a convenient tool for the quick approximation of savings attainable through recuperation. 
TABLE 4-6

TYPICAL RECUPERATED FURNACE HIGH-FIRE DATA NEAR TOP OF HEATING CYCLE

(RUN 5-3, 8-1-78)

Fuel flow, $1 \mathrm{~b} / \mathrm{min}\left(W_{F}\right)$

Combustion air flow, lb/min $\left(W_{A}\right)$

26.44

Exhaust gas flow prior to dilution, $1 \mathrm{~b} / \mathrm{min}\left(W_{G}\right)$

27.71

Exhaust gas/air flow after dilution, $\mathrm{lb} / \mathrm{min}$

45.86

Combustion air recuperator inlet temp., ${ }^{\circ} F\left(T_{1 A}\right)$

Combustion air burner inlet temp., ${ }^{\circ} F\left(T_{2 A}\right)$

1336

Exhaust gas combustion chamber outlet temp, ${ }^{\circ} F\left(T_{2 G}\right)$

1782

Exhaust gas/air recuperator inlet temp., ${ }^{\circ} F\left(T_{3 G}\right)$

1572

Exhaust gas/air recuperator outlet temp., ${ }^{\circ} F\left(T_{4 G}\right)$

Air/fuel mass ratio, dimensionless $\left(A / F=W_{A} / W_{F}\right)$

20.75

Gas/fuel mass ratio, dimensionless $\left(G / F=W_{G} / W_{F}\right)$

21.75

Air specific heat at constant pressure, $B T U / I b-{ }^{\circ} F\left(C_{P A}\right)$

0.256

Gas specific heat at constant pressure, $B T U / 1 b-{ }^{\circ} F\left(C_{P G}\right)$

0.288

Fuel net heat of combustion, BTU/Ib $\left(\mathrm{H}_{F}\right)$

21.210 
It is shown in Table 4-7 that the total cost of furnace modification, recuperator design and fabrication, and equipment installation was $\$ 39,821$. The average melting rate is 1.24 tons/day and the corresponding specific energy consumptions are 24.6 and $16.7 \mathrm{millions}$ of BTU/ton, respectively, for unrecuperated and recuperated furnace operation. At the current Class 2 natural gas billing rate of $\$ 2.1226$ per million BTU ( $\$ 0.21226$ per therm), the annual operating costs and recuperated savings are as follows:

$$
\begin{aligned}
& \text { Unrecuperated fuel cost }=(1.24)(365)(24.6)(2.1226)=\$ 23,633 \\
& \text { Recuperated fuel cost }=(1.24)(365)(16.7)(2.1226)=\$ 16,044 \\
& \text { Recuperated cost savings }=23,633-16,044=\$ 7,589 *
\end{aligned}
$$

On this basis, the payback period is $t_{p}=39.821 / 7.589=5.25$ years. This is not surprising when one considers the manner in which the furnace was operated. The rated capacity is $0.5 \mathrm{ton} / \mathrm{hr}$ or 12 tons/day. At an average loading of 1.24. tons/day, the furnace was operated at only ten percent of capacity; both fuel consumption and recuperated savings will be increased as furnace usage approaches capacity. This is demonstrated in Figure 4-8 in which daily energy consumption, daily energy savings, annual dollar savings, and payback period are plotted as functions of melting rate. At moderately low melting rates; energy consumption is essentially independent of melting rate; increases in loaș are covered by improvement in efficiency. For melting rates greater than 4 tons/day, specific energy consumption is nearly constant and total-energy consumption increases with load. At 8 tons/day (67 percent of capacity), cost savings. is increased to $\$ 12,800 / y r$ and the payback period is reduced to slightly more than three years.

The above is optimistic to the extent that it neglects the cost of capital and the effect of inflation, but, conversely, it takes no credit for the salvage value of the original blower and burners. Moreover, the furnace modification requirements were unfavorable because top-mounted burners were replaced with side-mounted burners. Finally, the cost reflects overtime labor as necessary. to maintain schedule. These considerations suggest that the capital. investment may have been greater than required for recuperation of other furnaces.

\section{RECUPERATOR PERFORMANCE}

The logic behind the method of recuperator performance evaluation has been explained above in the discussion under TEST RATIONALE. The evaluation parameters are derived in Appendix B. For both heat transfer and pressure drop, the evaluation standard is the calculated design condition. Since there is limited hardware- and greater operational-digression from the analysis conditions, absolute agreement with the evaluation standards is not as significant as change in performance over the year. As noted above, a decrease in recuperator performance could indicate leakage, plugging or fin erosion. An increase in pressure loss could indicate plugging; and a decrease in pressure loss could indicate leakage or fin erosion.

*The only maintenance operation was a burner adjustment which was provided without cost by the furnace modification contractor. 
TABLE 4-7

MCGOWAN FURNACE RECUPERATOR COST SUMMARY

$\underline{\text { tem }}$

1. Furnace modification

a. Eurners

b. Miscellaneous components

c." Ducts

d. Exhaust blower

e. Installation labor

f. Controls and instrumentation(1)

Total $(a-f)$

2. Recuperator installation in mounting frame and insulation

3. Freicht

4. Recuperator design and fabrication

Total

NOTES:

गัن

क $\frac{1}{\mathrm{n}}$

논

(1) Exclusive of test instrumentation

(2) Approximate.
Source

Amount

G-M Enterprises

8,594

6,862

2,890

1,483

7,546

1,620

29,085

G-M Enterprises

5,347

Ai Research

$\$ 39,821^{(2)}$ 


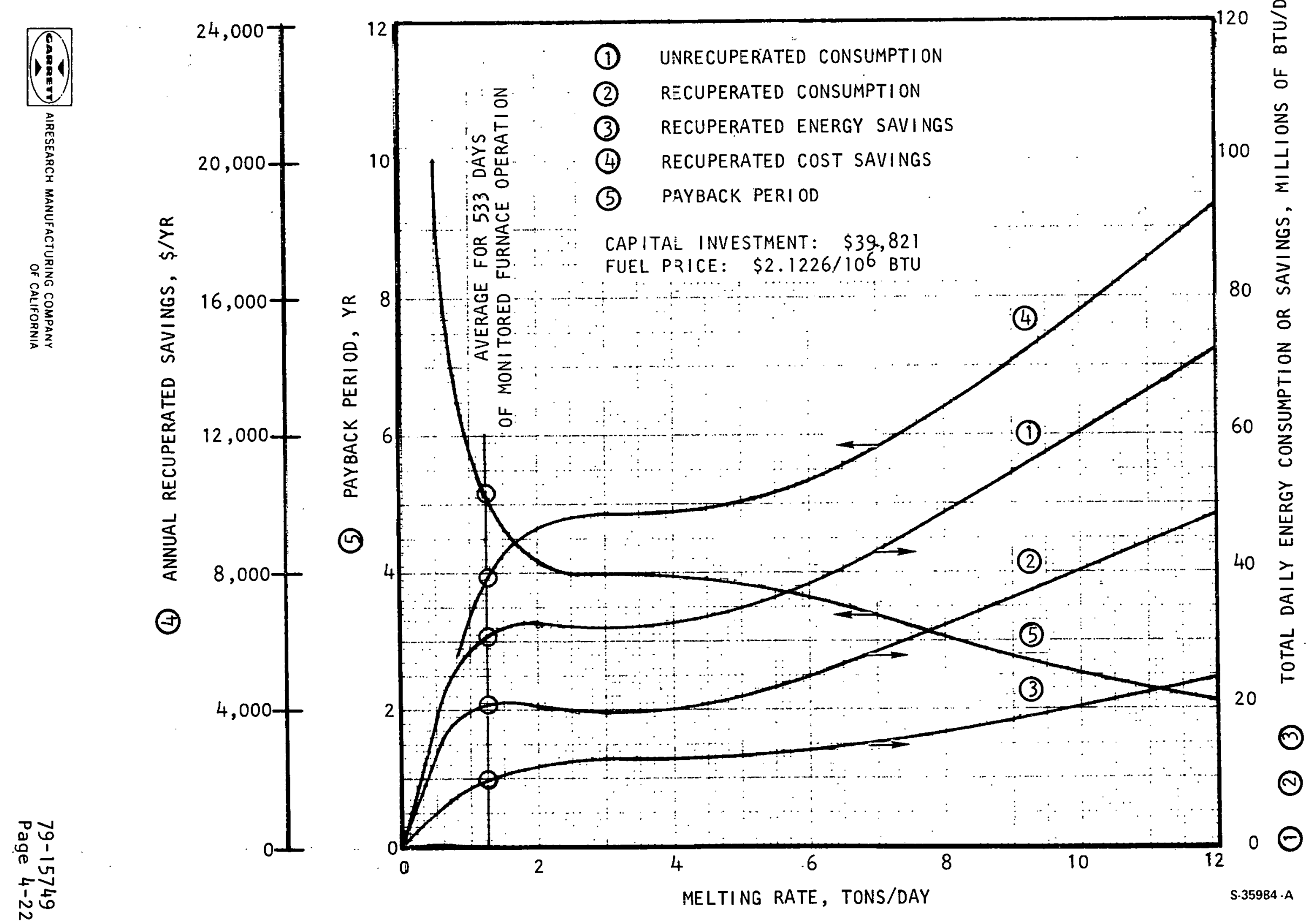

Figure 4-8. Effect of Daily Melting Rate on Energy Consumption, Savings and Payback Period 
A typical recuperator performance data sheet is shown in Figure 4-9. Six data sets are shown; of 127 data sets recorded, 50 were analyzed by the method of Appendix B. Forty-seven parameter sets considered representative of system performance are plotted chronologically in Figure 4-10. Overall heat transfer coefficient (UA) ratios and pressure loss ratios are plotted wi th corresponding recuperator exhaust gas inlet temperatures and aluminum melt temperatures. Significant temperature variation is noted because steady-state is never achieved in the course of furnace operation. The furnace oscillates in a transient pattern and temperatures were plotted to determine if there is a correlation between instantaneous transient condition and recuperator performance.

In evaluating performance, there are two factors which result in a shift of measured UA relative to the reference UA based on design conditions. First, the calculated exhaust gas flow ranges from 45 to $62 \mathrm{lb} / \mathrm{min}$ whereas the design value is $33.23 \mathrm{lb} / \mathrm{min}$. The effect is to increase the theoretical test UA relative to the design UA. The second source of discrepancy is related to the installation of the recuperator. Approximately 15 percent of the air inlet face of the core in the crossflow section was blocked by a flange which was attached by the installer. The loss of crossflow section heat transfer surface is not important, but the blockage will incur a nonuniform distribution of the air flow in the counterflow section. This maldistribution is only partially corrected by lateral adjustment through the slots as the air moves through the matrix; the effect is a decrease in UA and an increase in air pressure loss relative to respective design values.

The data analysis was executed on an "as-received" basis throughout the year. This resulted in early identification of what appeared to be a systematic increase in air pressure loss as a possible trend; subsequent measurements refute this supposition. What is clear is that the transient nature of the furnace operation and the instrumentation limitations discussed above combine to impose a wide range of scatter on the data.

There is one trend which is noteworthy. It is observed in Figure 4-10 that each of three decreases in air flow rate resulted in an increase of the pressure drop parameter; conversely, two air flow increases resulted in parameter decreases. This could be attributed to either (1) instrumentation inaccuracy or (2) error in the evaluation parameter. The effect of this anomaly is only to increase the scatter of the data. Although the combination of the initial air flow decrease in April and the gage recalibration in March suggested pressure drop was increasing wi th time, data recorded over the last three months are consistent with those recorded between the gage recalibration and the first flow decrease.

In addition to refuting the spurious pressure loss increase, this consistency also suggests that the low air pressure loss readings recorded prior to recalibration are inaccurate and should be disregarded in the data interpretation. This supposition is supported by the design analysis and the core inlet face blockage incurred in installation; air pressure loss should be higher, not lower, than calculated. 


\begin{tabular}{|c|c|c|c|c|c|c|c|c|c|c|c|c|c|c|c|c|c|c|}
\hline & 愨 & $\underset{⿱ 亠 䒑}{\stackrel{W}{上}}$ & 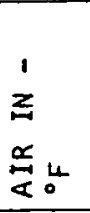 & 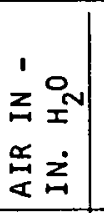 & $\begin{array}{l}1 \\
5 \\
5 \\
5 \\
50 \\
4\end{array}$ & \begin{tabular}{ll}
1 & \\
5 & 0 \\
0 & $x^{N}$ \\
0 & $\vdots$ \\
\hdashline & $z_{i=1}$
\end{tabular} & 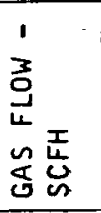 & 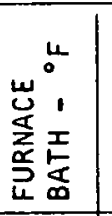 & 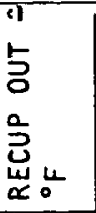 & 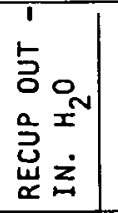 & 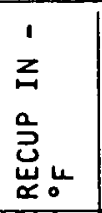 & 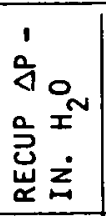 & 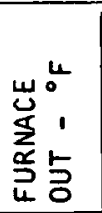 & 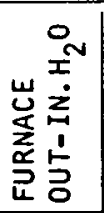 & 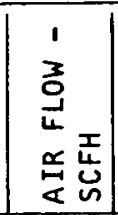 & 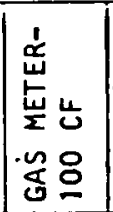 & 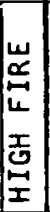 & \\
\hline No. & 1 & 2 & 3 & 4 & 5 & 6 & 7 & 8 & 9 & 10 & 11 & 12 & 13 & 14 & 15 & & & REMARKS \\
\hline 1 & $3 / 14 / 78$ & 0815 & 108 & 3.5 & $133 i$ & 1.5 & 1821 & 1173 & 868 & -2.05 & 1414 & 2.40 & 1522 & -.11 & 21240 & 88115 & $x$ & \\
\hline 2 & & & & & & & & & & & & & & & & & & \\
\hline 3 & $3 / 31 / 78$ & 1107 & 115 & 3.7 & 1486 & 1.7 & 1862 & 1202 & 957 & -2.23 & 1575 & 2.35 & 1835 & -.07 & 21220 & 89540 & $x$ & \\
\hline 4 & & & & & & & & & & & & & & & & & & \\
\hline 5 & $4 / 3 / 78$ & 1015 & 111 & 3.9 & 1474 & 1.7 & 1835 & 1193 & 944 & -2.25 & 1565 & 2.40 & 1898 & -.06 & $\$ 1300$ & & $x$ & \\
\hline 6 & & & & & & & & & & & & & & & & & & \\
\hline 7 & $4 / 18 / 78$ & 1305 & 122 & 4.0 & 1480 & 1.8 & 1778 & 1173 & 953 & -2.56 & 1590 & 2.44 & 1739 & -.21 & 21400 & 2929 & $x$ & \\
\hline 8 & & & & & & & & & & & & & & & & & & \\
\hline 9 & $4 / 25 / 78$ & 905 & 118 & 4.2 & 1453 & 1.9 & 1800 & 1191 & 927 & -2.34 & 1553 & 2.46 & 1648 & -.17 & 21640 & 94250 & $x$ & \\
\hline 10 & & & & & & & & & & & & & & & & & & \\
\hline 11 & $4 / 28 / 78$ & 1050 & 122 & 3.8 & 1469 & 1.6 & 1870 & 1161 & 969 & -2.45 & 1560 & 2.38 & 1777 & -.21 & 9900 & 94922 & $x$ & $\begin{array}{l}\text { Recalibrated gas flow } \\
\text { meter-lowered combus }\end{array}$ \\
\hline 12 & & & & & & & & & & & 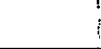 & & & & & & & tion air flow \\
\hline 13 & & & & & & & & . & & & & & & & & & & \\
\hline 14 & & & & & & & & & & & & & & & & & & \\
\hline 15 & & & & & & & & & & & & & & & & & & \\
\hline 16 & & & & & & & & & & & & & & & & & & \\
\hline 17 & & & & & & & & & & & & & & & & & & \\
\hline 18 & & & & & & & & & & & & & & & & & & \\
\hline 19 & & & & & & & & & & & & & & & & & & \\
\hline 20 & & & . & & & & & & & & & & & & & & & \\
\hline 21 & & & & & & & & & & & & & & - & & & & \\
\hline
\end{tabular}



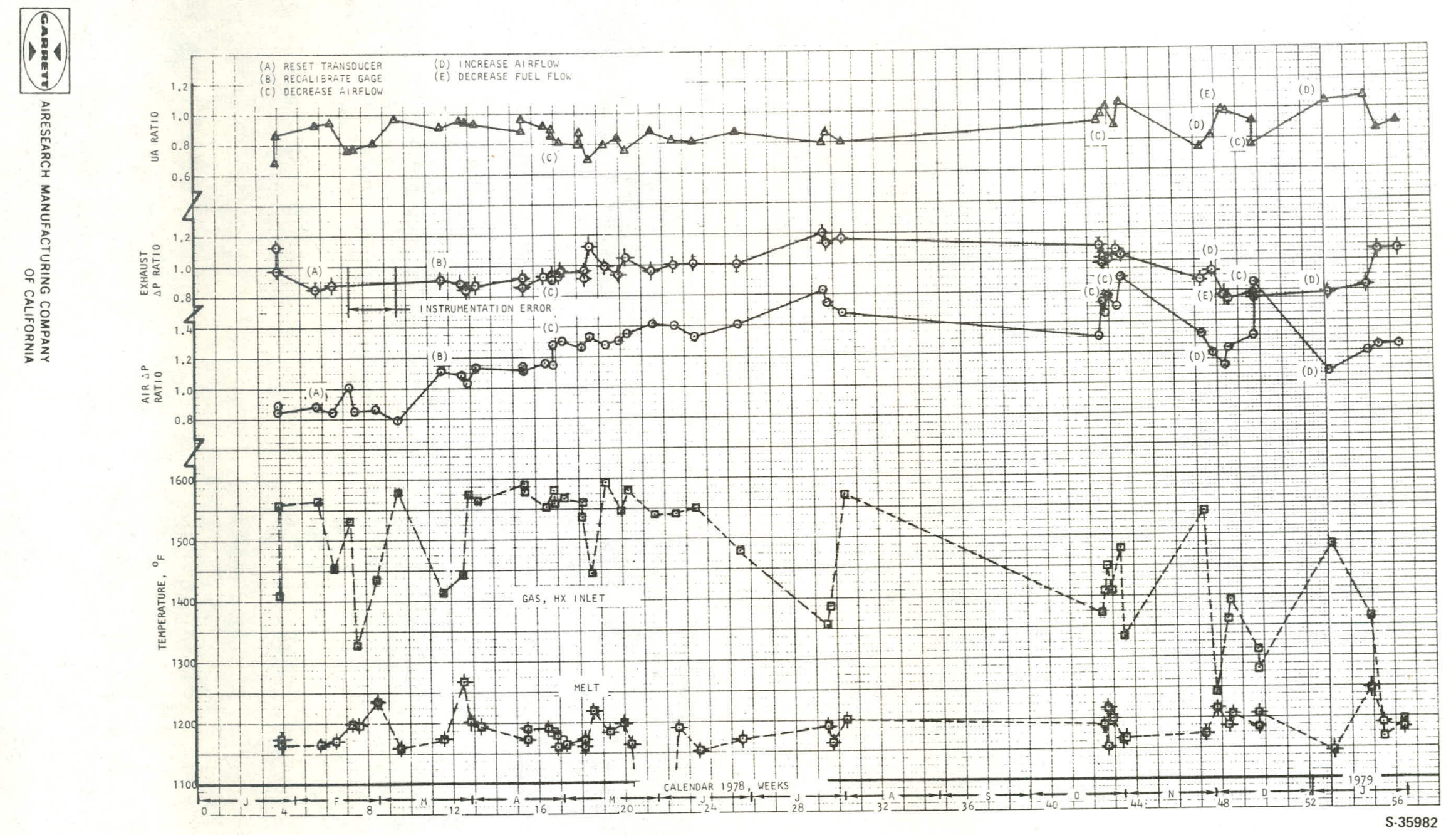

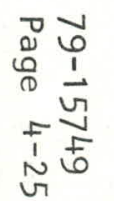

Figure 4-10. Effect of Time on Recuperator Performance 
In consideration of the above, the indication from Figure 4-10 is that performance is consistent at a level which exceeds the design requirement; there is no evidence of deterioration of any type over the twelve month period of recuperated operation. Specific observations are as follows:

1. Effect of exhaust recuperator inlet temperature: Inconclusive. In general, higher exhaust temperatures correspond to lower pressure losses, but there are exceptions and the data scatter obscures any trends. More consistent performance was expected at high temperatures because these conditions are closest to thermal equilibrium; at high temperature, recuperator structure heat storage is minimized.

2. Effect of melt temperature: No effect.

3. Heat transfer performance (UA Ratio): Constant with calendar time; no deterioration. Since $U A$ is a positive function of flow rate, the parameter should increase and decrease in accordance wi th the air flow adjustments. In four of the five adjustments such is the case, but the october flow decrease produced an apparent increase in.UA ratio.

4. Exhaust gas pressure loss (Exhaust $\Delta P$ Ratio): Constant wi th calendar time; no increase or decrease

5. Air pressure loss (Air $\triangle P$ Ratio): Constant wi th calendar time; no increase or decrease. As noted above, the data points prior to March recalibration are disregarded and there is an unexplained instrumentation or data reduction anomaly.

\section{REQUIRED MAINTENANCE; CONDITION OF FURNACE AND COMPONENTS} AFTER ONE YEAR OF RECUPERATED OPERATION

Recent photographs of the furnace are shown in Figures 4-11 through 4-13. After one year of recuperated operation, there is no evidence of physical deterioration of the furnace or any of $i$ ts ancillary equipment. The only maintenance operation was a burner fuel pressure adjustment in December. The recuperator was not inspected, but its performance has been consistent throughout the year and this is sufficient basis for concluding that no fouling, plugging or leakage has developed as of this writing.

The burner adjustment was requi red because the furnace had developed an opaque, yellow flame which is indicative of incomplete combustion. According to the furnace modification contractor, the fuel pressure had increased beyond the specified maximum and this resulted in incomplete mixing of the air and fuel. After pressure adjustment, it was observed that the fuel flow had been reduced by 38 percent relative to the initial recuperated fuel flow. Revicw of the early data revealed that a gradual fuel flow decrease trend began near the end of June. The combination of higher pressure and lower flow suggests an increased burner fuel pressure loss characteristic which might be caused by carbon deposition resulting from chemical breakdown of the natural gas prior to combustion. 


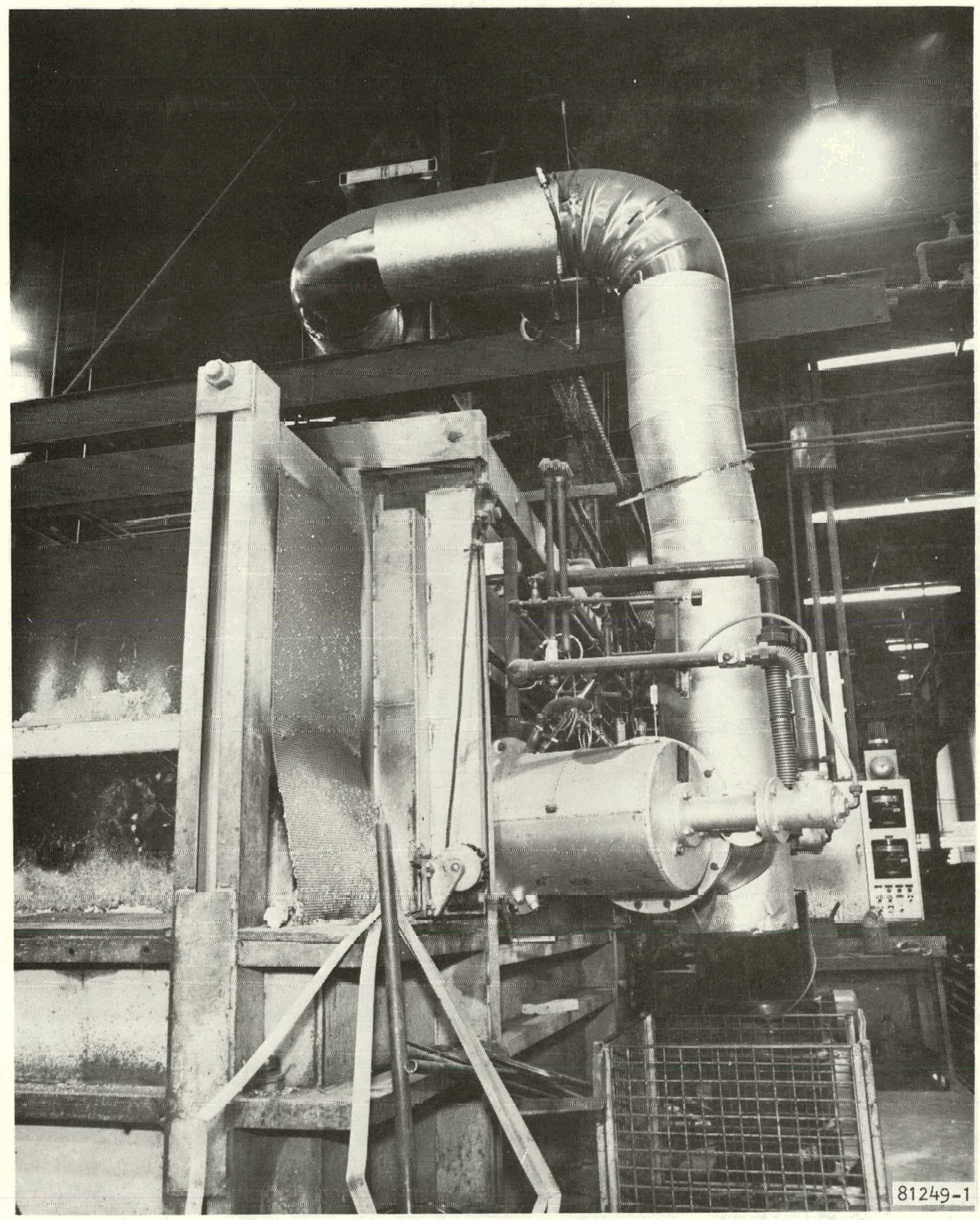

Figure 4-11. McGowan Furnace After One Year of Recuperated Operation; Vi ew From Northeast Showing Loading Door (Left), Burner, Recuperatorl, Burner Air Transition Duct, and Instrument Subpanel (Right) 


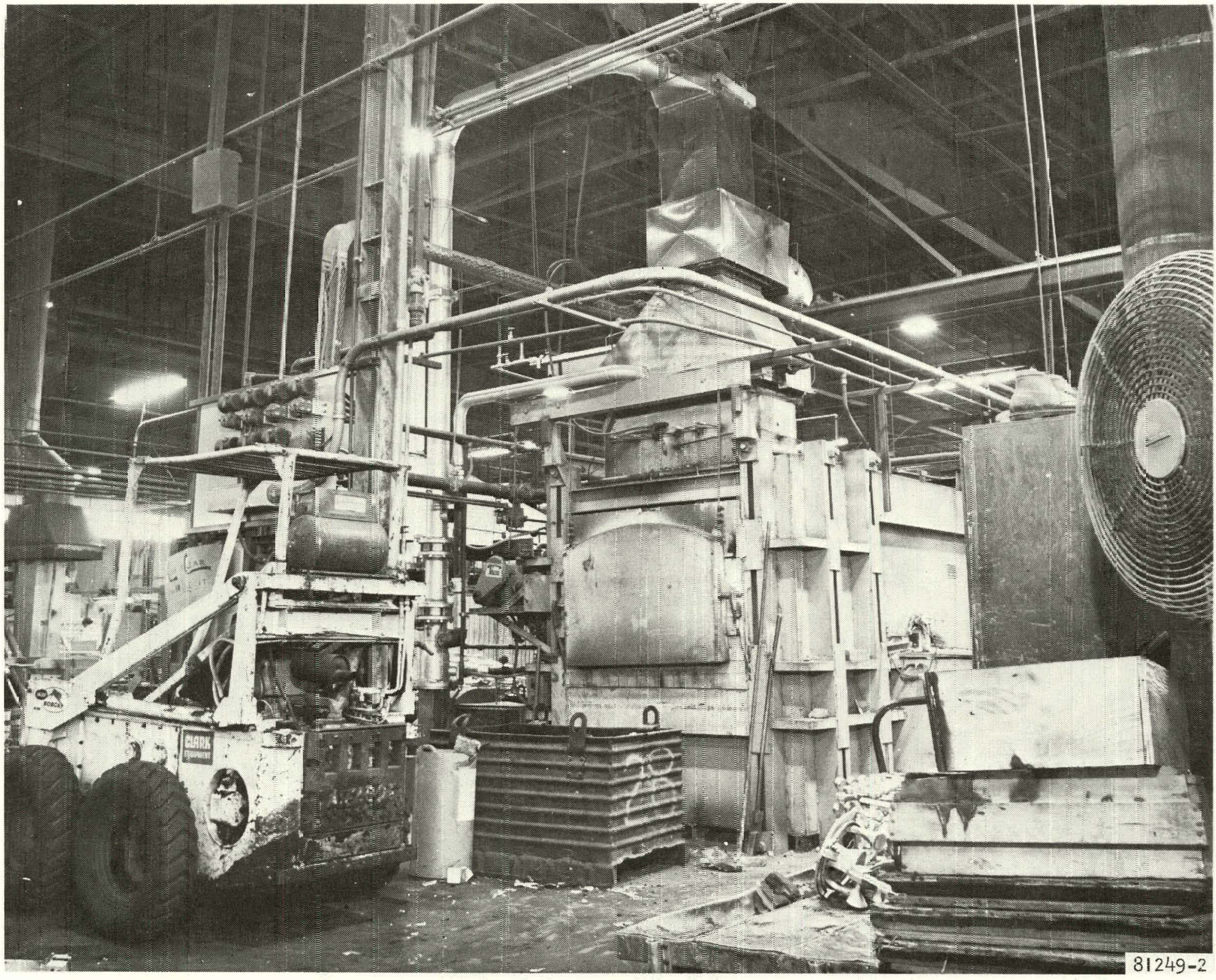

Figure 4-12. McGowan Furnace After One Year of Recuperatec Operation; View From Southwest showing Rear Door, Recuferator, and Exhaust Dilution Air Duct 


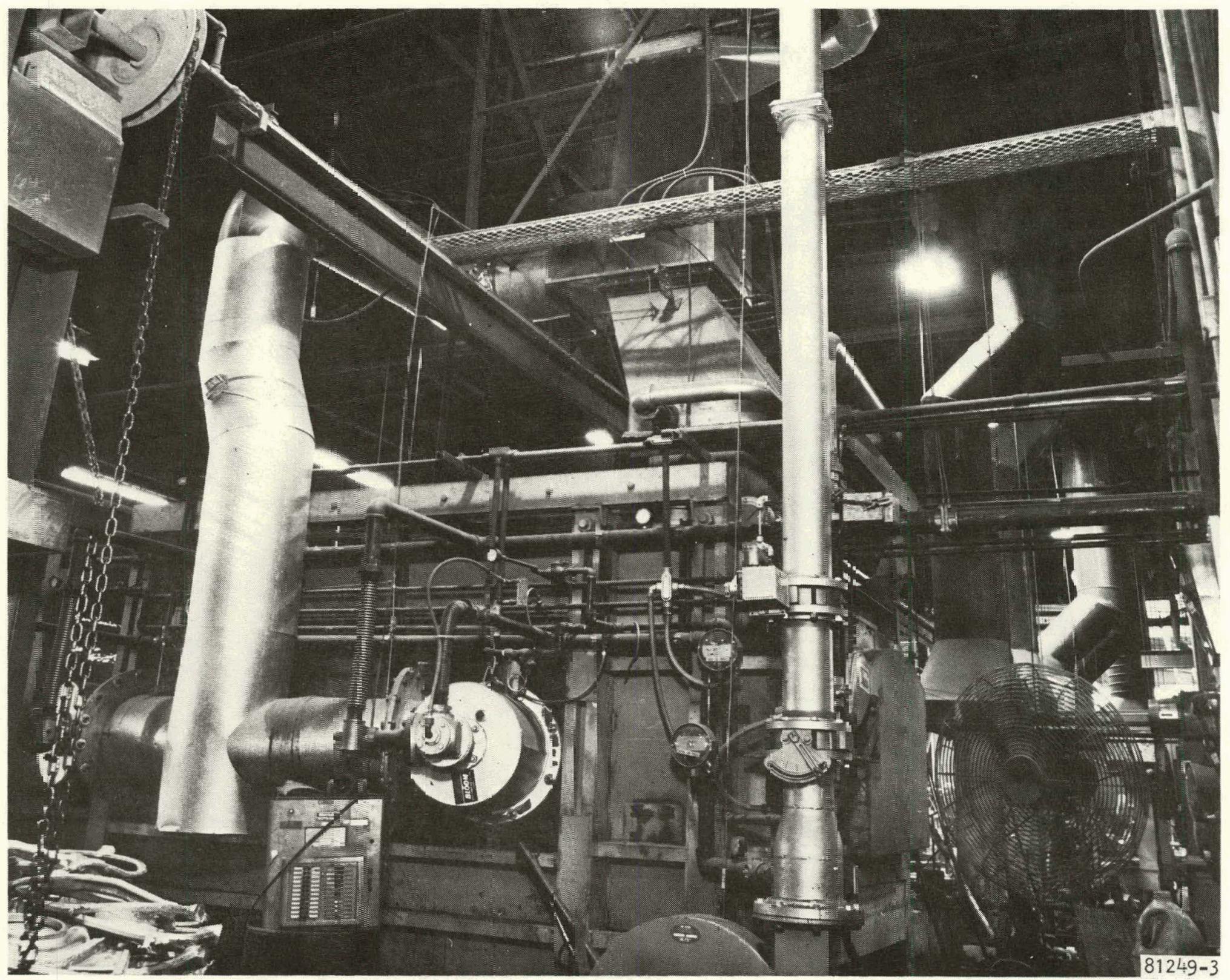

Figure 4-13. McGowan Furnace After One Year of Recuperated Jperation; Jiew From Northwest Stowing Combustion Air Blower (Bottom), Blower/Recuparator Air Transition Duct wi th Cortrol Damper and Flcwmeter Sections, Recuperator, Rezuperator/Burner Air Transition [ucts, and Burners 
The effect of the fuel flow rate decrease is to slow furnace response and thereby to require a greater percentage of operating time on high-fire. With stoichiometric combustion, the air flow is decreased proportionally and less energy is lost through the stack. The effectiveness of the recuperator is increased and the corresponding higher air preheat temperature might be beyond the tolerance of the burner. Wi thout a compensating air flow decrease, flame temperature and exhaust temperature are decreased. Heat recovery is impaired, but the $1550^{\circ} \mathrm{F}$ dilution requirement probably limits the loss to an extent that is innocuous.

The decreased rate of furnace response represents a loss of capacity which can be tolerated as long as the daily load rate is only ten percent of rated maximum. Production is impeded when the load rate approaches maximum, but the original characteristic of the burner can be restored by cleaning or replacement of the fuel supply tube. 


\section{SECTION 5}

\section{CONCLUSIONS AND RECOMMENDATIONS}

The following conclusions are drawn from the demonstration program:

1. Plate-fin heat exchangers can provide satisfactory heat recovery from natural gas exhaust products at temperatures up to $1550^{\circ} \mathrm{F}$.

2. Ninety-percent-effectiveness recovery can be maintained for periods in excess of one year wi thout recuperator maintenance. Recuperator maintenance requi rements are unknown because there has been no loss of performance or increase of air or gas pressure loss after one year of operation.

3. The need for periodic burner maintenance has not been definitely established, but such a requi rement seems likely. It is also probable that the frequency of maintenance will be a function of furnace usage; higher load rates may require more frequent maintenance.

4. Since the stack loss is proportional to the exhaust flow rate, the furnace should be operated at the minimum fuel and air flow which will satisfy load requirements. This is a near-stoichiometric fuel/ air mixture with just enough excess air to ensure complete combustion. In cases of operation with large quantities of excess air, furnace tuning to near-stoichiometric minimum flow may save more energy than recuperation.

5. The thermal analysis indicates that 29 percent of the heat is lost through the walls of the furnace and by radiation and natural convection from exposed portions of the charge. Additional insulation, a closed-door-when-not-loading policy, and provision of covers for the pouring wells can reduce this loss significantly.

6. Twenty percent of the exhaust gas energy is thermodynamically unavailable due to dilution upstream of the recuperator. Development of a high-temperature recuperator and compatible burner would eliminate the need for dilution; a program to this end is recommended.

7. With continuing fuel shortages and consequent cost increases, the application of high-technology plate-fin heat transfer concepts to flue-gas waste heat recovery is now economically feasibie. Within the next few years, such concepts will become more attractive and .. increasing use of plate-fin recuperators is forecast. 
APPENDIX A

SYSTEM THERMAL ANALYSIS

PROCEDURE

The thermal analysis is composed of the following steps which were performed in the listed sequence:

1. Development if a theory-based mathematical model of the system.

2. Comparison of model-based performance predictions with furnace test data; empirical adjustment of the model to improve the correlation between analysis and test.

3. Application of the model to a recuperated system to determine the optimum fuel/air flow rate combination.

\section{AINALYSIS SUMMARY}

The mathematical model is shown schematically. in Figure $A-1$. Combustion air from the foundry at a temperature $T_{1}$ is circulated through the recuperator where it is heated to the burner inlet temperature $\mathrm{T}_{2}$. Fuel is added and ignition increases the temperature of the combustion products to the flame temperature $\mathrm{T}_{3}$. Heat transfer to the charge and furnace heat losses cool the combustion: gas to $T_{4}$; chimney losses further cool the gas to the furnace outlet temperature $T_{5}$. To meet the structurally-imposed recuperator gas temperature limit, secondary cooling air is mixed with the exhaust to produce the recuperator inlet temperature ${ }^{6}{ }$. Heat transfer in the recuperator cools the exhaust mixture to $T_{7}$.

*For unrecuperated operation: $Q_{R}=0, T_{1}=T_{2}, T_{6}=T_{7}$ 


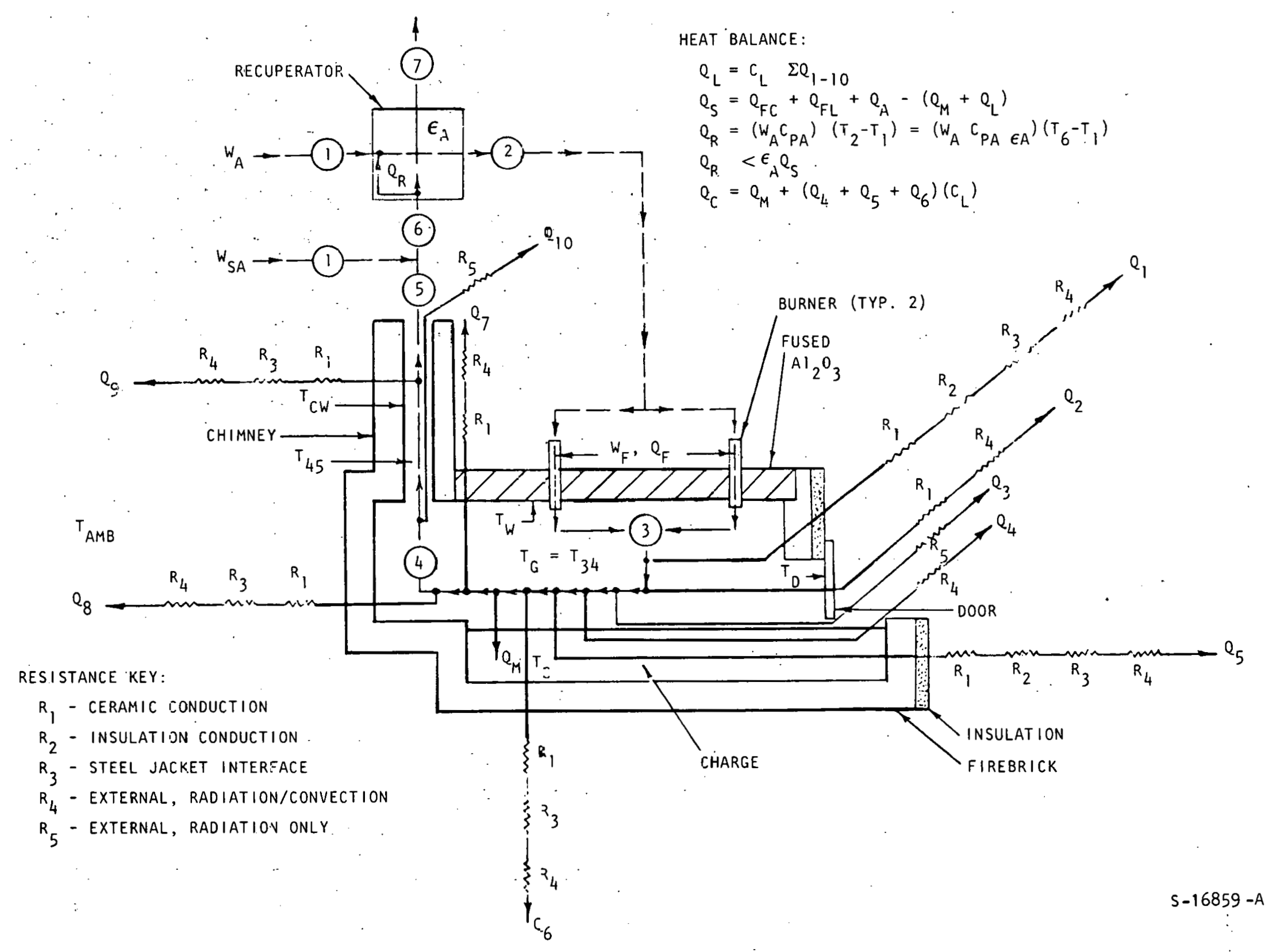


It is seen in Figure $A-1$ that charge heating and furnace losses reduce the temperature of the combustion products and that the heat transfer occurs over the temperature range $T_{3}-T_{5}$. Since (1) the gas temperature differential $T_{3}-T_{5}$ is a function of the charge heating and loss rates, and (2) the rates are detarmined by the magnitude of $T_{3}$ and $T_{5}$, it follows that the mathematical analysis procedure is one of iteration. Initlal values of $T_{4}$ and $T_{5}$ are assumed, the heating and loss rates are computed, and the gas temperature decreases are subsequently calculated from the heating and loss rates. Calculated values of $T_{4}$ and $T_{5}$ are compared with the assumed values and subsequent computations are based on the calculated values; the process is iterated until there is agreement between assumed and calculated values of both $T_{4}$ and $T_{5}$. For convenience, the charge heating and loss rate computations are based on the arithmetic average temperatures $T_{34}$ and $T_{45}$. This does not provide a rigorous simulation of the physical heat transter process, but accuracy is comparable to that of other assumptions required by the model; the empirical adjustments and final correlation with test data assure reasonable accuracy.

In developing the model, simplifying assumptions were formulated and the thermal resistances defined in Figure A-1 were calculated from theory. The resulting equations were applied to two unrecuperated reference test conditions and the calculated exhaust gas temperatures were compared with measured gas temperatures in the furnace chimney. The assumptions were then modified to improve the correlation between the model and test and the procedure was 
repeated. Two refinements of the initial model were required to secure the following correlations which correspond to Conditions 1 and 2 of Table A-1:

Source

Operating Condition

$\mathrm{T}_{4},{ }^{\circ} \mathrm{F}$

$\mathrm{T}_{5},{ }^{\circ} \mathrm{F}$

$\mathrm{T}_{45},{ }^{\circ} \mathrm{F}$
Analysis

1

2186

2014

2100
Test

1

$-$

$-$

1388 1958
Analysis Test

2

2

2214

1928

2071

1996, 1824

Comparison of analysis and test results is obscured by the fact that in no case is equilibrium actually obtained. In the analysis, the calculations indicate that the heat delivered to the charge exceeds the heat required to nold the charge at the assumed $1233^{\circ} \mathrm{F}$ equilibrium temperature. This implies that (i) the equilibrium temperature is above $1233^{\circ} \mathrm{F}$, (2) the heat delivered to the charge at equilibrium is less than calculated, and ( 3 ) the equilibrium exhaust temperature will be increased accordingly. In the test, the readings were taken at random. Not only was equilibrium not achieved, but it is very unlikely that the $1233^{\circ} \mathrm{F}$ charge temperature was approached because the burner remained "on" after the readings were taken. Thus, the test points represent transients on a charge-heating curve in which exhaust temperature follows charge temperature.

A measure of the degree of equilibrium approach in the analysis is the ratio of furnace heat output to heat input. For Conditions 1 and 2 in Table A-1, the respective values are 0.954 and 0.908 . This implies that equilibrium 
TABLE $A-1$

MCGOWAN FURNACE ANALYSIS SUMMARY.

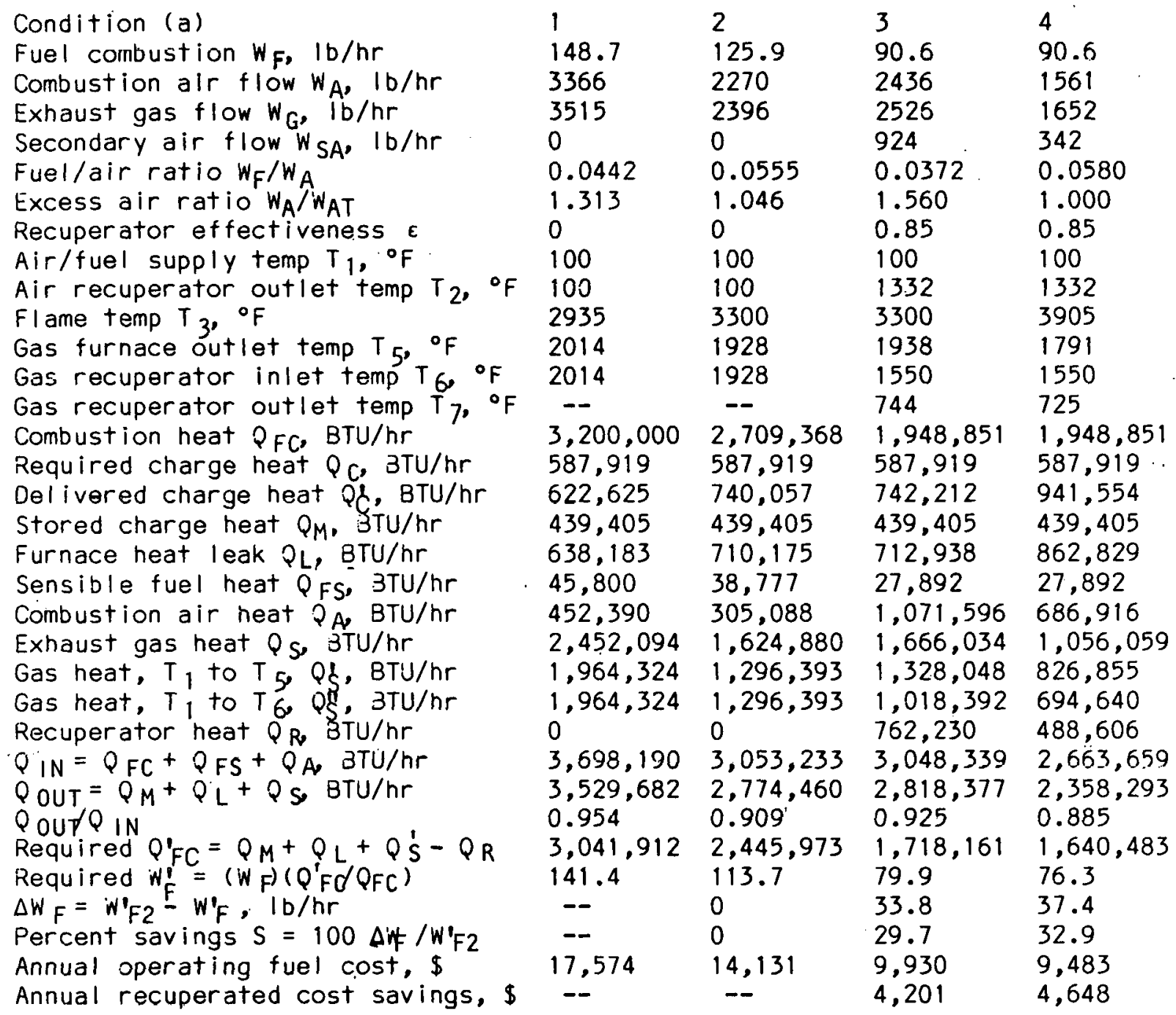

(a) Condition 1: Design QFG $W_{A}$ from test + $10 \%$ estimated leakage, $\mathrm{T}_{45-\mathrm{TEST}}=1888^{\circ} \mathrm{F}, 1958^{\circ} \mathrm{F}$

Condition 2: After furnace adjustment. WF from meter, W A from test + estimated leakage. T $45-\mathrm{TEST}=1996^{\circ} \mathrm{F}, 1824^{\circ} \mathrm{F}$

Condition 3: Recuperated operation willi $W_{A}$ and $T_{3}$ per Condition 2

Condition 4: Recuperated operation with stoichiometric combustion 
was at least approached in both cases. It is therefore concluded that the gas temperature increases required to reach equilibrium will be significantly greater for the test data than for the analytic predictions.

While the above explains in part the disparity between analysis and test, it is by no means implied that comparison on an equilibrium basis would eliminate all of the difference. The model is crude and a $100^{\circ} \mathrm{F}$ equilibrium disparity would be considered good agreement, certainly sufficient for the valid assessment of recuperator operating conditions.

Calculated theoretical and estimated actual flame temperatures for ambient and preheated combustion air are presented in Figures A-2 and A-3. The lower actual temperatures $T_{3}$ account for dissociation of the combustion products and other uncertain facets of the combustion process. The flame temperatures are plotted against the air flow ratio $W_{A} / W_{A T}$ in which $W_{A}$ is the air flow rate under consideration and $W_{A T}$ is the air flow rate required for stoichiometric combustion. Figures $A-2$ and $A-3$ show that:

1. Excess air decreases flame temperature.

2. At fixed fuel/air ratio $\left(W_{A} / W_{A T}=\right.$ constant), air preheat increases flame temperature by an amount which increases with the percentage of excess air, but which never exceeds the amount of preheat. These phenomena are functions of (1) the effect of temperature on specific heat at constant pressure, and (2) the relative magnitude of the specific heats of air and combustion products. 


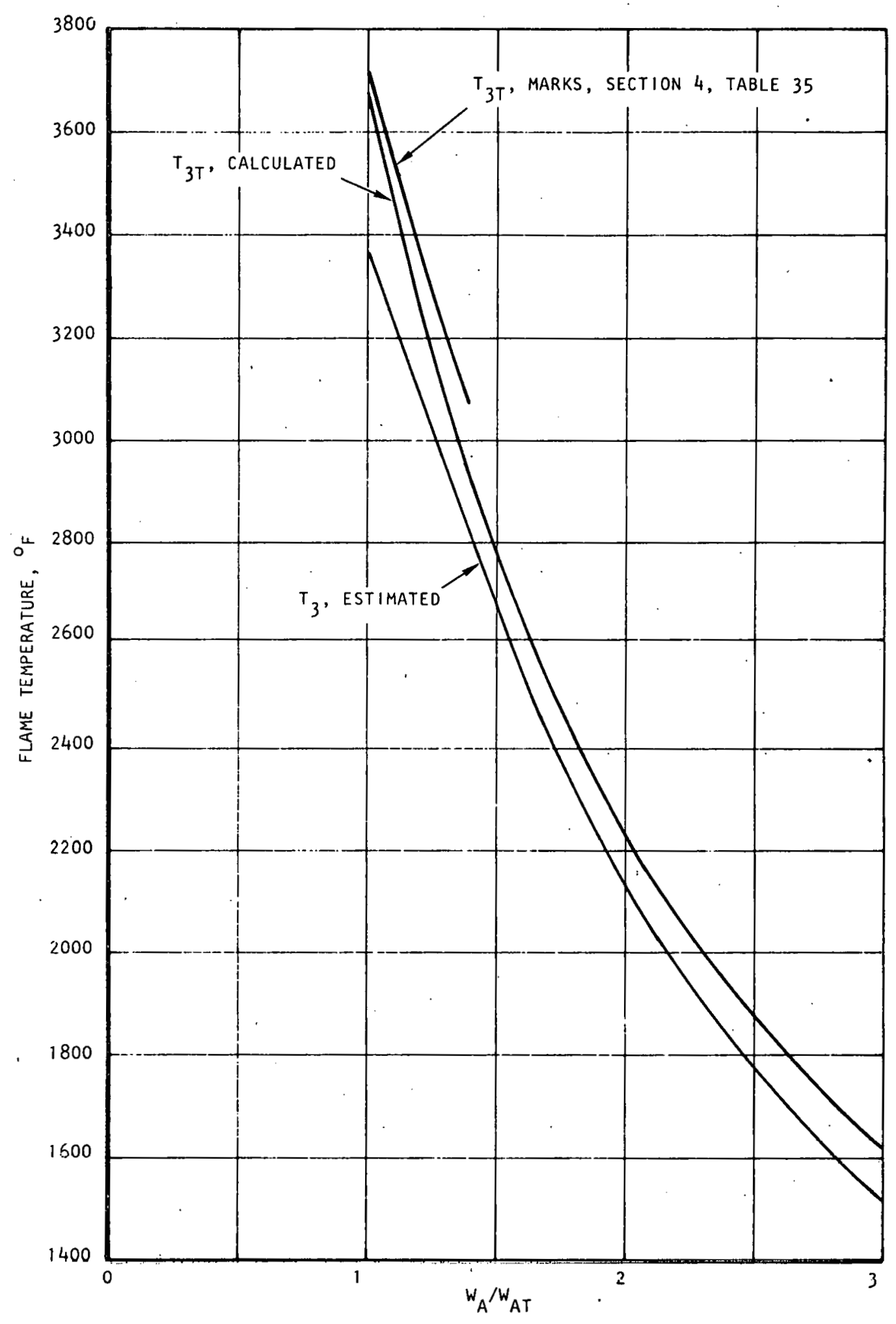

Figure A-2. Effect of Excess Air on Theoretical and Estimated Actual $\mathrm{Flame}$ Temperatures $\left(T_{A}=100^{\circ} \mathrm{F}\right)$ 


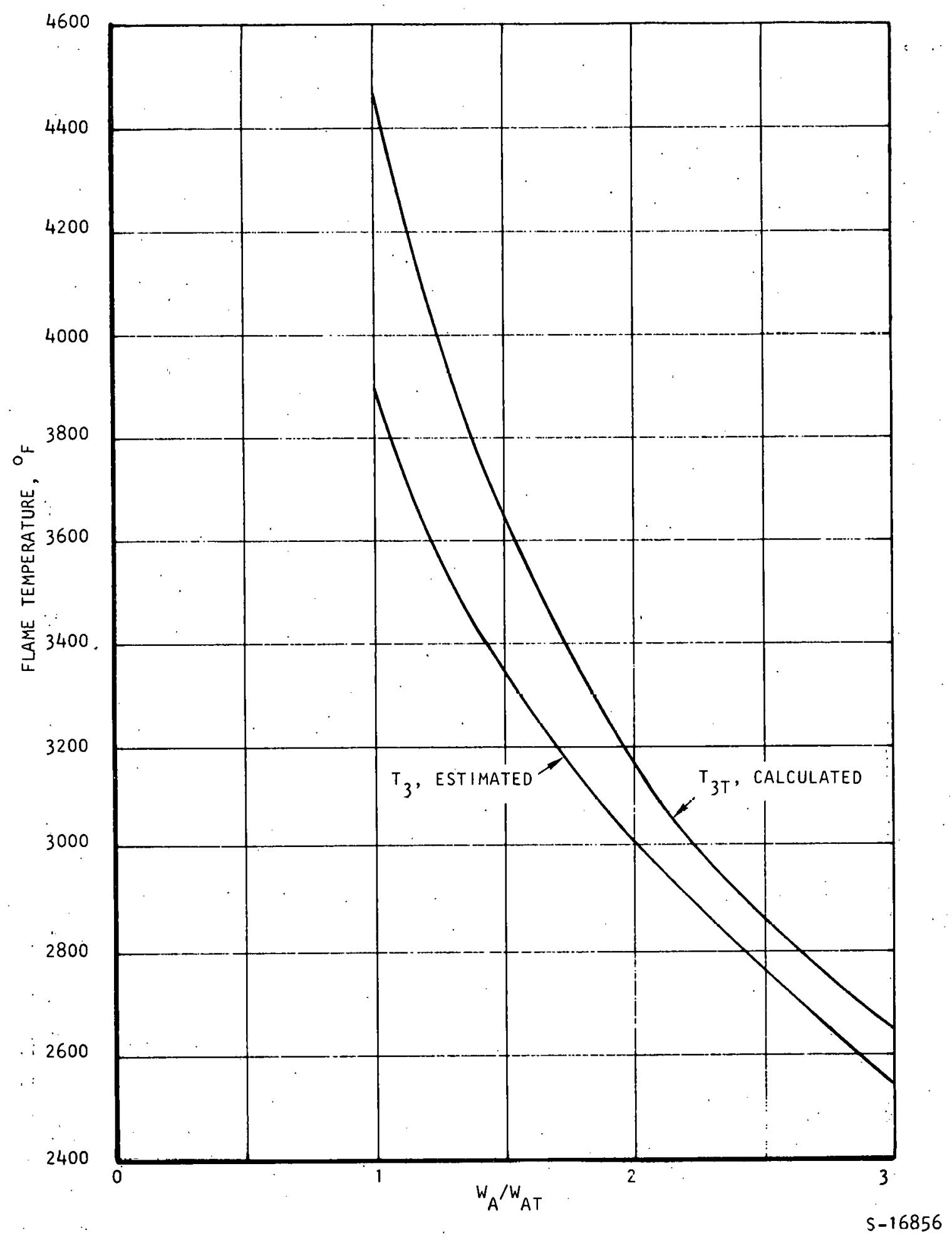

Figure A-3. Effect of Excess $A$ ir on Theoretical and Estimated Actual Flame Temperatures $\left(T_{A}=1332^{\circ} \mathrm{F}\right)$ 
The curves plotted in Figures $A-2$ and $A-3$ are the source of $T_{3}$ in the mathematical model.

Results of the analysis are summarized in Table A-1. Condition 1 represents the initial unrecuperated furrace operation at design conditions. A pitot survey in the blower discharge duct indicated that the air flow was consistent with the design fuel flow. Condition 2 represents unrecuperated furnace operation after burner and blower damper adjustment by a representative of Southern California Gas Company. Condition 3 represents recuperated furnace operation at the Condition 2 flame temperature. Condition 2 and Condition 3 air flows are essentially the same, but the Condition 2 fuel flow has been reduced in Condition 3 by the equivalent of the energy recovered in the recuperator. Finally, Condition 4 represents stoichiometric recuperated operation at the Condition 3 fuel flow.

In establishing the recuperator design constraints, the optimum system operating condition is defined as the minimum fuel flow and minimum air flow which will produce a charge heating rate equal to or greater than the Condition 2 charge heating rate. Since radiation accounts for 70 percent or more of the charge heating, flame temperature is the principal criterion of charge heating rate. The optimum operating condition, therefore, is that 
of minimum fuel and air flow. whose flame temperature equals or exceeds the $3300^{\circ} \mathrm{F}$ flame temperature of Condition $2 . *$

Referring to Figure $A-l$, the total energy addition to the furnace is

$$
Q=W_{F} H_{F}+\left(W_{A} C_{P A}\right)\left(T_{2}-T_{1}\right)
$$

where $Q$ = Furnace energy addition, BTU/hr

$$
\begin{aligned}
& W_{F}=\text { Fuel flow rate, } \mathrm{lb} / \mathrm{hr} \\
& H_{F}=\text { Fuel net heating value, BTU/Ib } \\
& W_{A}=\text { Air flow rate, Ib/hr } \\
& C_{P A}=\text { Air specific neat at constant pressure, BTU/Ib- }{ }^{\circ} \mathrm{F} . \\
& T_{1}=\text { Recuperator air inlet temperature, }{ }^{\circ} \mathrm{F} \\
& T_{2}=\text { Recuperator air outlet temperature, }{ }^{\circ} \mathrm{F}
\end{aligned}
$$

The analysis is based on the following constraints:

$$
\begin{aligned}
& \mathrm{H}_{F}=21,520 \text { BTU/ID (Methane) } \\
& T_{1}=100^{\circ} \mathrm{F} \\
& T_{6}=1550^{\circ} \mathrm{F} \\
& \epsilon_{A}=0.850
\end{aligned}
$$

By definition of ${ }^{A} A$,

$$
\begin{aligned}
& T_{2}=T_{1}+\left(\epsilon_{A}\right)\left(T_{6}-T_{1}\right)=100+(0.850)(1550-100)=1332^{\circ} \mathrm{F} \\
& T_{12}=(100+1332) / 2=716^{\circ} \mathrm{F} ; C_{P A}=0.2534 \mathrm{BTU} / \mathrm{lb}-{ }^{\circ} \mathrm{F}
\end{aligned}
$$

*This precept is qualified by the additional requirement that the air flow must be sufficient to preclude excessive cooling of the combustion products in the furnace, i.e., the exhaust temperature $T_{4}$ must exceed the charge temperature $\mathrm{T}_{C}$ by at least $400^{\circ} \mathrm{F}$. For the conditions analyzed, nearly all of the increased combustion product $\Delta T$ resulting from air flow reduction was reflected in flame temperature increase:

$\begin{array}{cccc}\text { Condition } & 2 & 3 & 4 \\ \mathrm{~T}_{3},{ }^{\circ} \mathrm{F} & 3300 & 3300 & 3905 \\ \mathrm{~T}_{4}{ }^{\circ} \mathrm{F} & 2214 & 2223 & 2342 \\ \mathrm{~T}_{34},{ }^{\circ} \mathrm{F} & 2757 & 2762 & 3124\end{array}$


Substituting for $H_{F}, C_{P A}, T_{1}$ and $T_{2}$ in Equation (1):

$$
Q=21,520 W_{F}+312.19 W_{A}
$$

The air flow rate $W_{A}$ can be expressed in terms of the fuel flow rate $W_{F}$ and the fuel/air ratio $W_{F} / W_{A}$ :

$$
w_{A}=w_{F} /\left(w_{F} / w_{A}\right)
$$

Substituting for $W_{A}$ in Equation (1A):

$$
Q=21,520 W_{F}+312.19 W_{F} /\left(W_{F} / W_{A}\right)
$$

Solving for $W_{F}$ in terms of $Q$ and $W_{F} / W_{A}$ :

$$
W_{F}=Q /\left(21.520+312.19 /\left(W_{F} / W_{A}\right)\right)
$$

As noted above, Condition 2 fuel consumption is the evaluation standard. If it is assumed that the energy addition to the furnace should equal the heat of combustion at Condition 2:

$$
\begin{aligned}
& Q=Q_{F C 2}=2,709,3688 T U / h r \\
& W_{F}=2,709,368 /\left(21,520+312.19 /\left(W_{F} / W_{A}\right)\right)
\end{aligned}
$$

The fuel/air ratio is related to the stoichiometric fuel/air ratio and the air flow ratio $W_{A} / W_{A T}$ by Equation (3) below. For stoichiometric combustion of methane, $W_{F} / W_{A T}=0.0580$ :

$$
W_{F} / W_{A}=\left(W_{F} / W_{A T}\right) /\left(W_{A} / W_{A T}\right)=0.0580 /\left(W_{A} / W_{A T}\right)
$$

Equations (1C) and (3) can be used in conjunction with Figure $A-3$ to determine the relationships between flame temperature, air flow, and fuel flow. These relationships are plotted in Figure A-4.

If the $3300^{\circ} \mathrm{F}$ equivalent flame temperature criterion is applied, it is seen in Figure A-4 that, for equal heat addition, the minimum permissible fuel consumption is $90.6 \mathrm{lb} / \mathrm{min}$, the fuel/alr ratio is 0.0372 , and the air flow is $2436 \mathrm{lb} / \mathrm{hr}$. This is Condition 3 of Table A-1; the distribution and rates of heat transfer within the furnace are nearly identical to those of Condition 2 

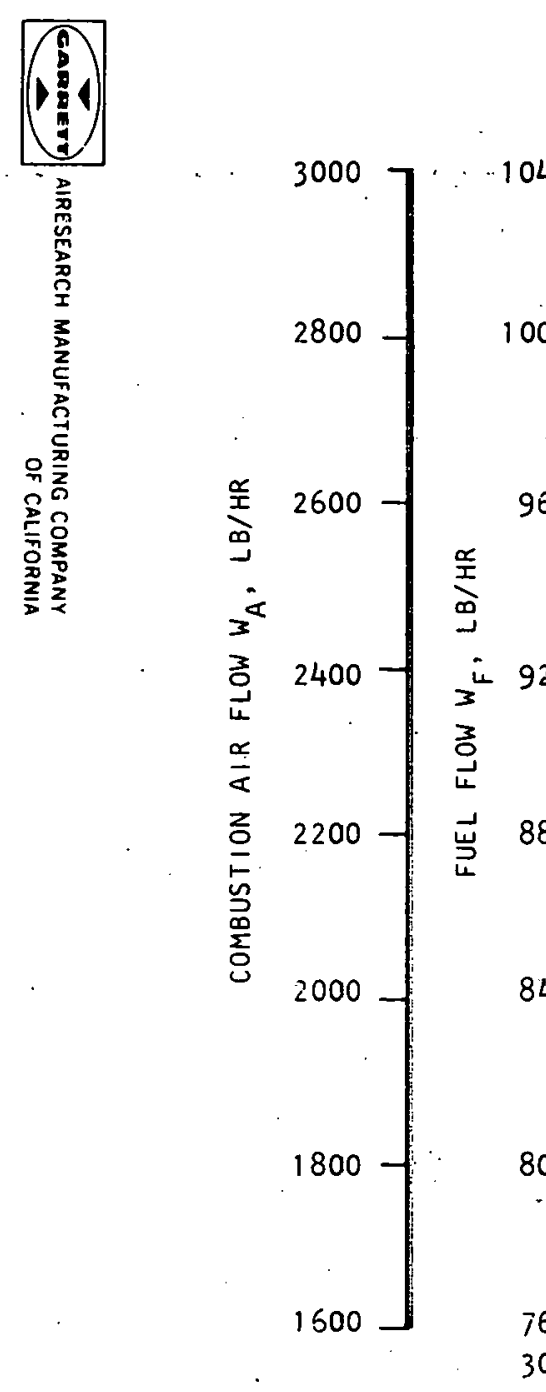

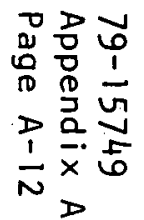

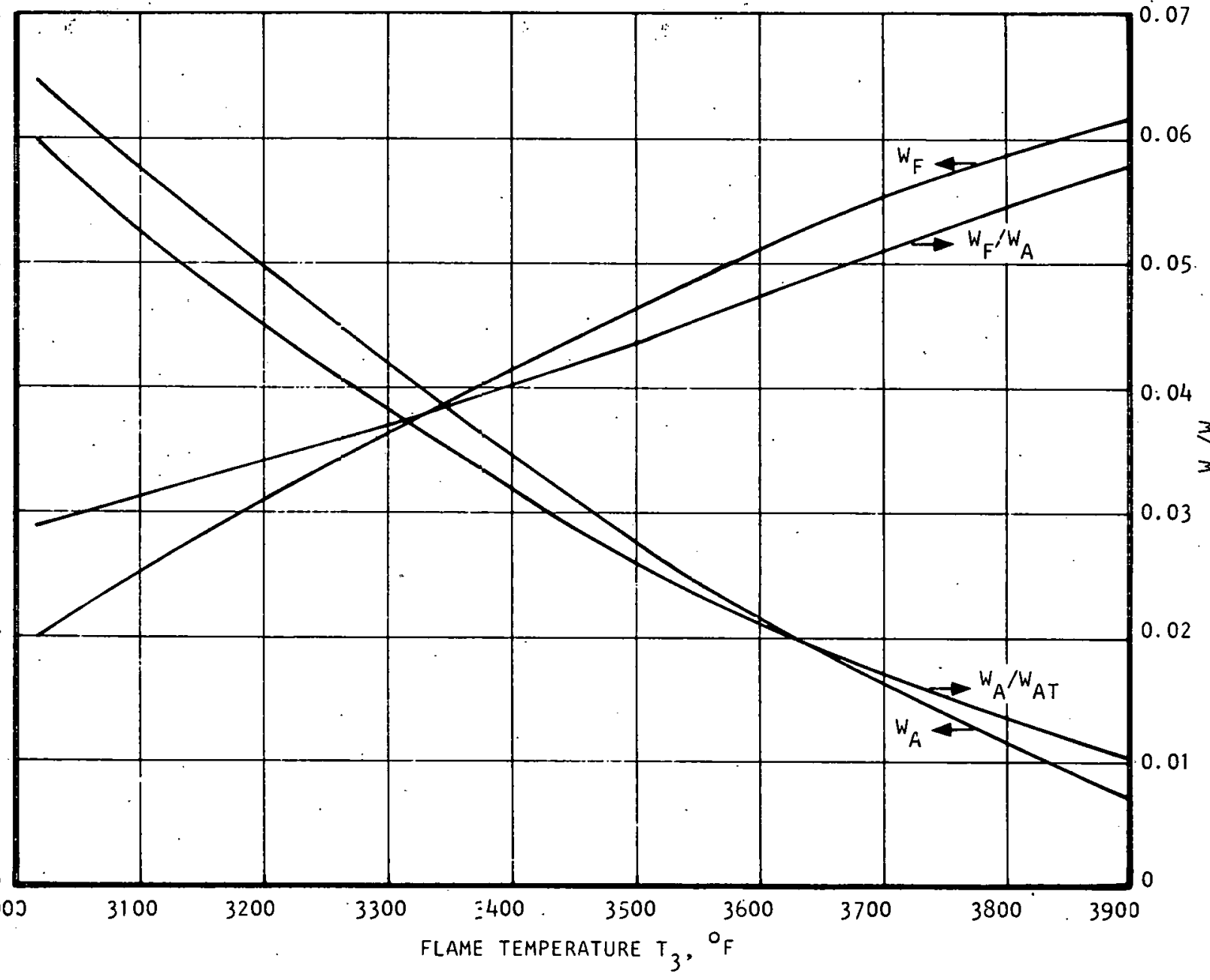

2.2

2.0

Figure A-4. Effect of Air. F.low and Fuel Flow on Flame Temperature for 2,709,368 3TU/Hr Furnace Heat Addition 
but $762,230 \mathrm{BTU} / \mathrm{hr}$ is recovered in the recuperator. The fuel consumption is reduced by $762,230 \div 21,520=35.4 \mathrm{lb} / \mathrm{hr}$.

If the furnace is.operated stoichiometrically at $90.6 \mathrm{lb} / \mathrm{hr}$ fuel consumption (Condition 4), the flame temperature is increased from $3300^{\circ} \mathrm{F}$ to $3905^{\circ} \mathrm{F}$. The energy recovery in the recuperator is decreased, but this is compensated by a reduction in the energy carried into the stack. Since the recuperated stack loss is proportional to the product of air flow rate and. ineffectiveness of the recuperator $\left(W_{A} \times\left(1-\epsilon_{A}\right)\right)$, maximum conservation of energy is achieved at minimum flow.

In addition to the above, the higher flame temperature increases the rate of charge heating and the lower air flow decreases the physical size of the heat exchanger, blowers, and ducts. It can therefore be concluded that, from a thermodynamic standpoint, the system should be operated stoichiometrically at the lowest fuel flow rate which satisfies charge heating requirements. Other aspects of furnace operation are not considered in the preceding analysis:

1. There are adverse effects of the higher flame temperature.

a. Dissociation and $\mathrm{NO}_{x}$ formation are more severe.

b. Burner design may be complicated.

c. Steady-state furnace wall and structure thermal gradients and stresses are higher.

d. Transient thermal stresses and dimensional excursions are greater.

2. Fuel consumption measurements indicate that, under conditions of Intermittent feed, the charge heating capacity of the furnace greatly exceeds both typical feed and design melting rate requirements. Consequently, as controlled by a sensor immersed in the 
charge, combustion is required for only 25 to 50 percent of the time during which the furnace is operating. The furnace is expected to operate continuously for 51 weeks out of every year.

In selecting the design constraints for the recuperator, it is assumed that the negative aspects of high-temperature operation can be tolerated* and the increased heating rate will merely result in a greater percentage of burner "off" time.

Condition 4 is selected as the furnace operating point; air leakage into the furnace will provide sufficient excess to ensure complete combustion. The $1550^{\circ} \mathrm{F}$ recuperator gas temperature restriction requires the ingestion of 22 percent** secondary cooling air between the furnace chimney exit (Station 5 , Figure $\mathrm{A}-1$ ) and the recuperator inlet (Station 6 ). This imposes a 16.7 percent penalty on heat recovery. The ingestion of secondary cooling air also increases the thermal capacity of the exhaust stream such that its recuperator outlet temperature is $725^{\circ} \mathrm{F}$.

The assumed fuel combustion rate is the same for Conditions 3 and 4 of Table A-1. This appears to imply that the two conditions are equivalent in terms of consumption and economy. This is not true, however. In all cases, the required charge heating rate $Q_{C}=587,919 \mathrm{BTU} / \mathrm{hr}$ is exceeded by $Q_{C}^{\prime}$, the heat

*One particularly important factor is NOX formation. The $3905^{\circ} \mathrm{F}$ Flame temperature appears marginal for NO formation. A preliminary calculation indicates that furnace dwell time for combustion product cooling is sufficient to ensure effective decomposition of any NO prior to exhaust.

$* *$ Percent of combustion air. 
delivered to the charge. The highest rate of charge heating is at Condition 4 . This implies that the burner will be off for a greater percentage of the time when operating under Condition 4; fuel consumption will thereby be minimized. The savings can be assessed quantitatively by multiplying the analysis fuel flow by the ratio of the sum of required melting heat and net heat loss to the assumed combustion heat. The result is the required fuel consumption:

$$
\begin{aligned}
& Q_{F C}^{\prime}=Q_{M}+Q_{L}+Q_{S}^{\prime}-Q_{R} \\
& W_{F}^{\prime}=\left(W_{F}\right)\left(Q_{F C}^{\prime} / Q_{F C}\right)
\end{aligned}
$$

where $Q_{f}^{\prime}=$ Required fuel heat addition, $B T U / h r$

$$
\begin{aligned}
Q_{M}= & \text { Stored charge heat, BTU/hr } \\
\ddot{Q}_{L}= & \text { Furnace heat loss, BTU/hr } \\
Q_{S}^{\prime}= & \text { Available exhaust gas energy prior to dilution and } \\
& \text { relative to } 100^{\circ} \mathrm{F} \text { air inlet temperature, }{ }^{\circ} \mathrm{F} \\
Q_{R}= & \text { Recuperator heat recovery, BTU/hr } \\
W_{F}= & \text { Assumed fuel consumption, Ib/hr } \\
W_{F}^{\prime}= & \text { Required fuel consumption, } 1 \mathrm{~b} / \mathrm{hr} \\
Q_{F C}= & \text { Assumed fuel heat addition, BTU/hr }
\end{aligned}
$$

The required fuel consumption rates calculated for Conditions 3 and 4 are 79.9 and $76.3 \mathrm{lb} / \mathrm{hr}$, respectively. Theoretically, recuperated performance would match present performance with stoichiometric combustion of $76.3 \mathrm{lb} / \mathrm{hr}$ of fuel. The selected $90.6 \mathrm{lb} / \mathrm{hr}$ provides a margin of conservatism intended to compensate any optimism in the analysis. The higher rate of fuel supply will not increase overall consumption significantly because the burner will be off for a greater percentage of the furnace operating time.

The effect of the distribution of energy addition with time, i.e., the effect of the breakdown of the burner on-off cycle was not evaluated in this 
analysis. Nor was the effect of continuous modulated fuel combustion compared with intermittent maximum combustion. Such studies are based on transient analysis of the system; a much higher level of furnace detail is required and the effort is beyond the scope of this program. It is unlikely, however; that absolute minimum fuel consumption is consistent with rapid response requirements.

\section{EFFECT OF NATURAL GAS COMPOSITION}

The primary component of natural gas is methane $\left(\mathrm{CH}_{4}\right)$, and some sources produce gas which contains as much as 96 percent methane by volume. Other sources may produce gas which contains up to 31 percent ethane $\left(\mathrm{C}_{2} \mathrm{H}_{6}\right)$. To simplify the calculations, this system analysis was based on operation with pure methane, and the $1561 \mathrm{lb} / \mathrm{hr}$ air flow is that required for stolchiometric combustion of methane. If the McGowan furnace is supplled with natural gas of high ethane content, its density and the volumetric alr/fuel ratio for stolchiometric combustion will both be greater. For 31 percent ethane content, the specifled $1561 \mathrm{lb} / \mathrm{min}$ air flow would be two percent lower than required. This is an extreme case and furnace leakage would probably make up the deficiency. Nevertheless, exhaust gas samples will be subjected to periodic Orsat analysis after the modified system is put into position. Any indication of carbon monoxide in the exhaust will require that the combustion air flow be increased as necessary to secure complete combustion. The secondary air. flow wlll be reduced accordingly and the total exhaust flow to the recuperator will be essentially unchanged. 


\section{APPENDIX B \\ METHOD OF RECUPERATOR TEST DATA ANALYSIS}

Heat transfer performance and pressure loss are functions of flow rate; therefore, data comparisons should account for test flow variations. Such variations can be conveniently considered in pressure loss analys is, but heat transfer performance is simultaneously affected by both flows. Consequently, the effect of flow variations on heat transfer is more difficult to isolate. in the interest of expediency, it was decided to account for flow variation in the pressure loss analyses, but neglect it in the heat transfer analysis. In all cases, the evaluation standard is the calculated value of the parameter at the recuperator design condition.

\section{Heat Transfer}

Anticipated recuperator performance is in the range of 90 percent airside effectiveness where

$$
\begin{aligned}
& E_{A}=\left(\frac{T_{2 A}-T_{1 A}}{T_{1 G}-T_{1 A}}\right)(100) \\
& E_{A}=\text { Airside heat transfer effectiveness, dimensionless. } \\
& T_{1 A}=A i r \text { inlet temperature, } O_{F} \\
& T_{2 A}=\text { Air outlet temperature, }{ }^{O} F \\
& T_{1 G}=\text { Diluted exhaust gas temperature at recuperator inlet, }{ }^{O_{F}}
\end{aligned}
$$

According to the Second Law of Thermodynamics, the air outlet temperature, $T_{2 A}$ cannot exceed the exhaust inlet temperature $T_{1 G}$ without the addition of work. $T_{1 G}$ is the limiting value of $T_{2 A}$; as $T_{2 A}$ approaches $T_{1 G}$, the heat driving temperature differential $T_{1 G}-T_{2 A}$ is progressively decreased. This requires a progressive increase in heat transfer surface such that, with any $f$ inite heat transfer coefficient, 100 percent effectiveness requires a heat exchanger of infinite physical size. It follows that, for a heat exchanger of fixed finite size in the range of 90 percent effectiveness, significant changes in the heat transfer coefficient UA have only slight effect on the outlet temperature $T_{2 A}$ and $i$ ts corresponding effectiveness. Therefore, in the anticipated operating range, effectiveness is not a practical parameter on which to evaluate possible gradual changes in performance.

A better evaluation criterion is the overall coefficient of heat transfer UA. Although a measured value of $E_{A}$ is used to determine UA, the effect of small variation in $E_{A}$ is amplified in the translation. Fouling or plugging effects are therefore easier to detect when UA is the evaluation standard.

The overall coefficient of heat transfer UA is a function of air stream heat capacity, the ratio of air stream capacity to exhaust stream capacity, and recuperator effectiveness. Expressed mathematically, 


$$
\begin{aligned}
& \frac{U A}{W_{A} c_{P A}}=f\left(E_{A}, \frac{W_{A} c_{P A}}{W_{G} c_{P G}}\right) \\
& U_{A}=\text { overall coefficient of heat transfer, BTU/min }-{ }^{O_{F}} \\
& W_{A}=\text { Air flow rate, } 1 \mathrm{~b} / \mathrm{min} \\
& { }_{C P A}=A \text { ir specific heat capacity at constant pressure, BUT/Ib }-{ }^{\circ} \mathrm{F} \\
& W_{G}=\text { Exhaust flow rate, } 1 \mathrm{~b} / \mathrm{min} \text {. } \\
& { }_{C P G}=\text { Exhaust specific heat capacity at constant pressure, } B T U / 1 b-{ }^{\circ} F
\end{aligned}
$$

The above relationship has been calculated by a number of investigators for several flow configurations over a wide range of parameters. This work has been summarized in the literature (References $8-11$ ).

In reducing the recuperator test data, the heat absorbed by the preheat air is first calculated as the product of flow rate, specific heat and temperature increase:

$$
\begin{aligned}
Q_{A}= & \left(W_{A} C_{P A}\right)\left(T_{2 A}-T_{1 A}\right) \\
& Q_{A}=\text { Heat absorbed by preheat air, BTU/min }
\end{aligned}
$$

It is assumed that recuperator heat leak to the surroundings is insignificant. Exhaust flow is then calculated from the heat absorbed by the air, the exhaust temperature, and the exhaust specific heat:

$$
W_{G}=\frac{Q_{G}}{\left(c_{P G}\right)\left(T_{1 G}-T_{2 G}\right)} \approx \frac{Q_{A}}{\left(c_{P G}\right)\left(T_{1 G}-T_{2 G}\right)}
$$

Flow stream capacity ratio and effectiveness are calculated and the ratio $U A / W_{A} C P A$ is read from a reference curve at $E A$ and $W_{A C P A} / W_{G} C P G$. Finally, UA is calculated as the product of (UA/WACPA) and WACPA.

The heat transfer evaluation parameter is the ratio of test heat transfer coefficient to design heat transfer coefficient:

$$
\text { UA Ratio }=U A_{\text {TEST }} /{ }_{\text {DESIGN }}=U A_{\text {TEST }} / 30.18
$$




\section{Exhaust Gas Pressure Loss}

The effect of density variations is accounted for by the dimensionless factor $\sigma$ which relates test conditions to the design conditions:

$$
\begin{aligned}
& \sigma=\rho_{A V G}-\text { TEST } / \rho_{A V G}-\text { DESIGN } \\
& \rho_{A V G} \approx 144 P_{A V G} /(53.35)\left(T_{A V G}+460\right)=2.7 P_{A V G} /\left(T_{A V G}+460\right) \\
& P_{A V G}=\left(P_{1}+P_{2}\right) / 2 ; T_{A V G}=\left(T_{1}+T_{2}\right) / 2
\end{aligned}
$$

The units of pressure and temperature are psia and ${ }^{\circ} \mathrm{F}$. Subscripts 1 and 2 denote inlet and outlet, respectively. For the design condition, $P 1_{G-D}=$ $14.40 \mathrm{psia}, \Delta P_{G D}=1.244^{\circ}$ inches of $\mathrm{H}_{2} \mathrm{O}$, and $T_{A V G-G-D}=1098^{\circ} \mathrm{F}$ :

$$
\begin{aligned}
& P_{2 G-D}=14.40-1.244 / 27.7=14.36 \mathrm{psia} \\
& P_{A V G-G-D}=(14.40+14.36) / 2=14.38 \mathrm{psia} \\
& \sigma_{G}=\frac{\frac{2.7 P_{A V G-G-T}}{P_{A V G-T E S T}}=\frac{\frac{\left(T_{A V G-G-T}+460\right)}{(2.7)(14.38)}}{(1098+460)}=\frac{108.34 P_{\text {AVG }-G-T}}{T_{A V G-G-T}+460}}{}
\end{aligned}
$$

Nearly all of the pressure loss is due to flow friction in the heat transfer matrix. The flow is laminar and the slope of the friction factor curve is -0.46 . The effect of flow rate variation is:

$$
\begin{aligned}
& f_{G} \sim \frac{1}{W_{G}^{0.46}} \\
& \Delta P_{G} \sim f_{G} W_{G}^{2} \sim \frac{W_{G}^{2}}{W_{G}^{0.46}} \sim W_{G}^{1.54} \\
& \Delta P_{G}=\text { Exhaust gas pressure loss, inches of } H_{2} 0 \\
& f_{G}=\text { Fanning friction factor, dimensionless }
\end{aligned}
$$

Combining the density and flow rate effects,

$$
\frac{\sigma_{G} \Delta P_{G}}{W_{G}{ }^{1.54}}=\text { CONSTANT }
$$


For the design condition, $\sigma_{G}=1$ and $W_{G}=33.231 \mathrm{~b} / \mathrm{min}$

$$
\left(\frac{\sigma_{G} \Delta P_{G}}{W_{G}^{1.54}}\right)_{\text {DES IGN. }}=\frac{(1)(1.244)}{(33.23)^{1.54}}=0.005645
$$

$$
\text { Exhaust } \Delta P \text { Ratio }=\frac{\left(\frac{\sigma_{G} \Delta P_{G}}{W_{G}^{1.54}}\right)_{\text {TEST }}}{\left(\frac{\sigma_{G} \Delta P_{G}}{W_{G}^{1.54}}\right)_{D E S I G N}}=\frac{\left(\frac{\sigma_{G} \Delta P}{W_{G}^{1.54}}\right)_{T E S T}}{0.005645}
$$

\section{Air Pressure Loss}

The air pressure loss is analyzed in the same manner as the gas pressure loss with two exceptions:

1. The primary combustion air is clean and matrix plugging is not anticipated. The test pressure should always be approximately equal to design pressure. This assumption simplifies the calculation of $\sigma_{A}$. The design average air temperature is $760^{\circ} \mathrm{F}$ :

$$
\sigma_{A}=\frac{760+460}{T_{A V G-A}+460}=\frac{1220}{T_{A V G-A}+460}
$$

2. Most of the loss is in the end sections where the flow is turbulent. For the frictional portion of the end section loss,

$$
\begin{aligned}
& \Delta P_{A-E F} \sim W_{A}^{1.8} \\
& \Delta P_{A-E F}=\begin{array}{l}
\text { End section air pressure loss attributable to flow } \\
\text { friction, inches of } \mathrm{H}_{2} \mathrm{O}
\end{array}
\end{aligned}
$$

There is significant kinetic energy loss associated with the inlet flow contraction, the turns into and out of the counterflow heat transfer matrix, and the outlet flow expansion. These losses are proportional to the square of flow rate:

$$
\begin{aligned}
& \Delta P_{A-K E} \sim W_{A}^{2} \\
& \Delta P_{A-K E}=\text { Air kinetic energy pressure loss, inches of } \mathrm{H}_{2} \mathrm{O}
\end{aligned}
$$


Assuming that the end section frictional and kinetic energy losses are of the same magnitude,

$$
\begin{aligned}
& \Delta P_{A-E} \sim W_{A}^{1.9} \\
& \Delta P_{A-E}=\text { End section total air pressure loss, inches of } \mathrm{H}_{2} \mathrm{O}
\end{aligned}
$$

In the counterflow section, the flow is laminar. The relationship is as developed for the exhaust gas:

$$
\begin{aligned}
& \Delta P_{A-C O} \sim W_{A}^{1.54} \\
& \Delta P_{A-C O}=\text { Counterflow section pressure losis, inches of } \mathrm{H}_{2} \mathrm{O}
\end{aligned}
$$

Assuming a linear relationship between the exponent of $W_{A}$ and the distribution of the loss as calculated in the design analys is:

$$
\begin{aligned}
& \text { Exponent } n=(0.688)(1.9)+(0.312)(1.54)=1.79 \\
& \frac{\sigma_{A} \Delta P_{A}}{W_{A}^{1.79}}=\text { CONSTANT }
\end{aligned}
$$$$
\Delta P_{A}=\text { Total recuperator air pressure loss, inches of } \mathrm{H}_{2} \mathrm{O}
$$

For the design condition, $\sigma_{A}=1, \Delta P_{A}=1.753$ inches of $H_{2} 0$, and $W_{A}=26.021 \mathrm{~b} / \mathrm{min}$

$$
\begin{aligned}
& \left(\frac{\sigma_{A} \Delta P_{A}}{W_{A}^{1.79}}\right)_{\text {DESIGN }}=\frac{(1)(1.753)}{(26.02)^{1.79}}=0.005133 \\
& \text { Air } \Delta P \text { Ratio }=\frac{\left(\frac{\sigma_{A} \triangle P_{A}}{1.79}\right)_{\text {TEST }}}{\left(\frac{W_{A} \Delta P_{A}}{W_{A}^{1.79}}\right)_{D E S I G N}}=\frac{\left(\frac{\sigma_{A} \triangle P_{A}}{1.79}\right)_{T E S T}}{0.005133}
\end{aligned}
$$




\section{APPENDIX C}

\section{FUEL SAVINGS WITH RECUPERATION}

\section{ASSUMPTIONS :}

1. The exhaust gas combustion chamber outlet temperature $T_{2 G}$ is the same for unrecuperated and recuperated furnace operation.

2. The air/fuel ratio $(A / F)$ and exhaust-gas/fuel ratio (G/F) are the same for unrecuperated and recuperated operation.

3. The net heat added to the combustion chamber is the same for unrecuperated and recuperated furnace operation.

4. The disposition of the net heat addition between the charge and combustion chamber heat loss is the same for unrecuperated and recuperated operation.

5. The system air inlet temperature is $0^{\circ} \mathrm{F}$.

6. The enthalpy of air is zero at $0^{\circ} \mathrm{F}$.

7. The enthalpy or ex!laust gas is zero at $0^{\circ} \mathrm{F}$.

8. The internal energy and mechanical energy of the fuel are negligible.

The net heat added to the combustion chamber per unit of fuel consumption is

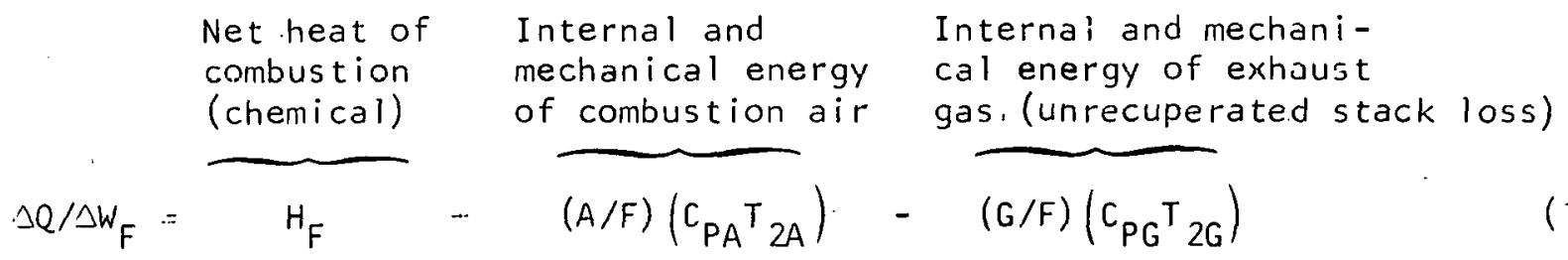

For the unrecuperated case, $T_{2 A}:=T_{1 A}=0$ :

$$
\Delta Q / \Delta W_{F O} \cdot H_{F}-(G / F)\left(C_{P G}^{\top}{ }_{2 G}\right)
$$

By definition, the percent fuel savings is

$$
S=\left(\left(W_{F O}-W_{F R}\right) / W_{F 0}\right)(100)=\left(1-W_{F R} / W_{F O}\right)(100)
$$


Since the net heat addition $Q$ must be the same for recuperated and unrecuperated operation,

$$
\frac{W_{F R}}{W_{F O}}=\frac{\left(\Delta Q / \Delta W_{F O}\right)}{\left(\Delta Q / \Delta W_{F R}\right)}
$$

Substituting in Equation (2) from (3):

$$
S=\left[1-\frac{\left(\Delta Q / \Delta W_{F O}\right)}{\left(\Delta Q / \Delta W_{F R}\right)}\right][100]
$$

Substituting in (2A) from (1) and (1A):

$$
S=\left[1-\frac{H_{F}-(G / F)\left(C_{P G}{ }^{T} 2 G\right)}{H_{F}+(A / F)\left(C_{P A}{ }^{\top} 2 A\right)-(G / F)\left(C_{P G}{ }^{\top} 2 G\right)}\right][100]
$$

Assumptions 3-6 are eliminated if the temperatures $T_{2 A}$ and $T_{2 G}$ in Equation 1 are replaced by the respective temperature differences $T_{2 A}-T_{1 A}$ and $T_{2 G}-T_{1 A}$. Equation (2B) becomes

$$
S^{\prime}=\left[1-\frac{H_{F}-(G / F)\left(C_{P G}\right)\left(T_{2 G}-T_{1 A}\right)}{H_{F}+(A / F)\left(C_{P A}\right)\left(T_{2 A}-T_{1 A}\right)-(G / F)\left(C_{P G}\right)\left(T_{2 G}{ }^{-T_{1 A}}\right)}\right]\lceil 100]
$$

\section{NOMENCLATURE}

$C_{P A}: \quad$ Air specific heat capacity at constant pressure based on average of $T_{1 A}$ and $T_{2 A}$, BTU/Ib- $F$ (or BTU/f $t^{3}-{ }^{\circ} F$ )

$C_{P G} \quad$ Exhaust gas specific heat capacity at constant pressure based on average of $T_{1 A}$ and $T_{2 G}$, BTU/Ib- ${ }^{\circ} \mathrm{F}$ (or BTU/ $\mathrm{ft}^{3}-{ }^{\circ} \mathrm{F}$ )

$\mathrm{H}_{\mathrm{F}} \quad$ Fuel net heat of combustion, BTU/lb (or $\mathrm{BTU} / \mathrm{ft}^{3}$ )

Q. Net combustion chamber heat addition, BTU/hr

S Fuel savings with recuperated operation, percent of unrecuperated consumption 


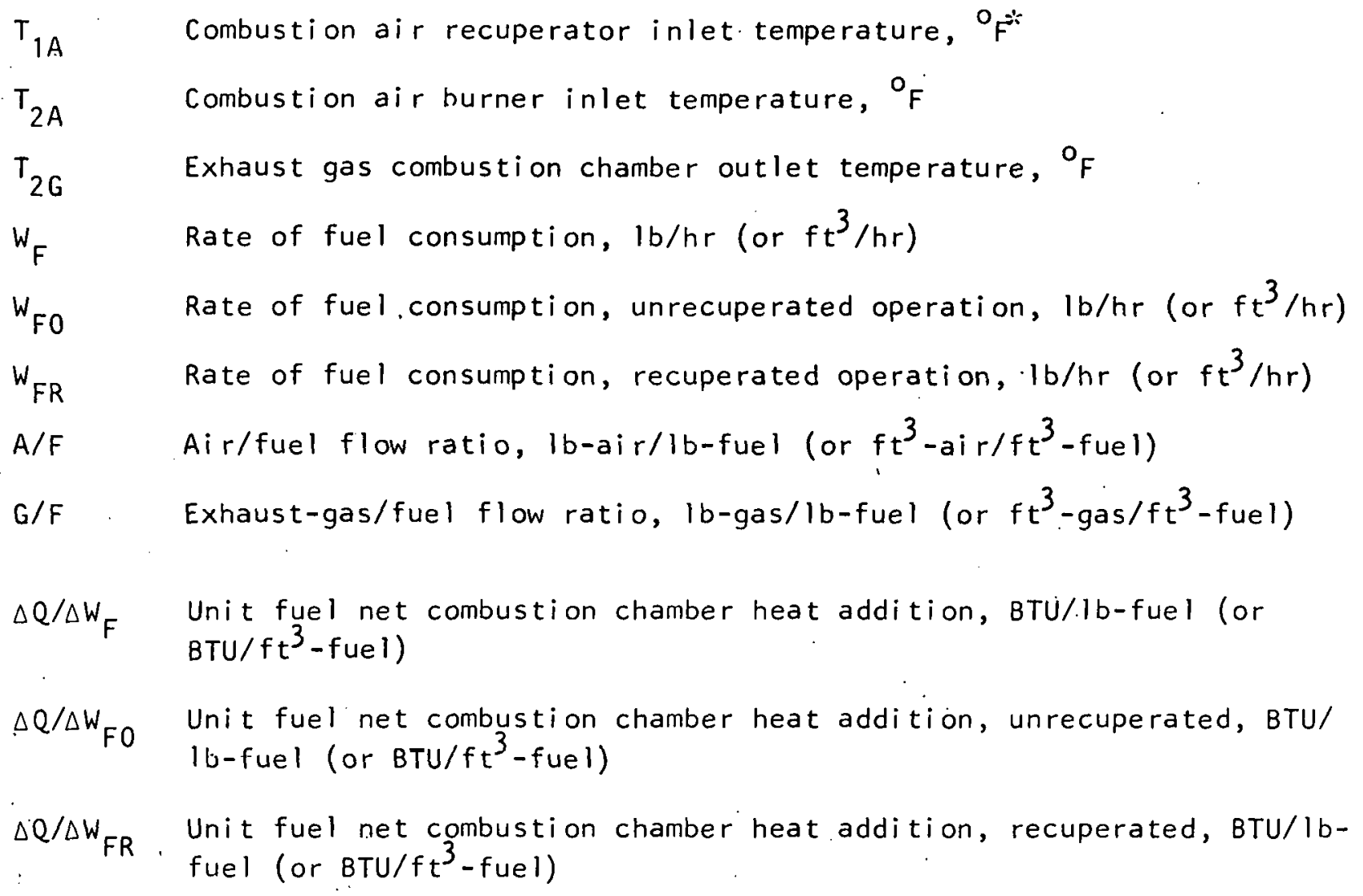

*In Equation (2C), $T_{1 A}$ is assumed to be the ambient temperature in the vicinity of the furnace and the fuel inlet temperature at the burner. 


\section{REFERENCES}

1. Gerstner, M. T., and R. T. Stake; Survey of Potential Energy Savings Using High Effectiveness Recuperators for Waste Heat Recovery from Industrial Flue Gases, AiResearch Report 77-14483, October 15, 1977.

2. McAdams, W. H., Heat Transmission, 3rd Edition, McGraw-Hill, 1954.

3. Kreith, F., Principles of Heat Transfer, International, 1958.

4. Brown, A. I., and S. M. Marco, Introduction to Heat Transfer, 2nd Edition, McGraw-Hill, 1951:

5. Perry, J.H., Chemical Engineers' Handbook, 3rd Edition; 1950.

6. Marks, L. S., Mechanical Engineers Handbook, 5th Edition, McGraw-Hill, 1951.

7. Poferl, D. J., R. A. Svehla, and K. Lewandowski, "Thermodynamic and Transport Properties of Air and the Combustion Products of Natural Gas and of ASTM-A-1 Fuel With Air," NASA TN D-5452; October 1969.

8. Kays, W. M., and A. L. London, Compact Heat Exchangers, 2nd Edition, McGraw-Hil1, 1964 :

9. Stevens, R. A., and J. R. Woolf, "Mean Temperature Difference in One-, Two-, and Three-Pass Cross-Flow Heat Exchangers: Part 1, Counter-Current Exchangers," ASME Paper No. 55--A-90, 1955.

10. Fernandez, J, and J. R. Stevens, "Mean Temperature Difference in One-, Two-, and Three-Pass Cross-Flow Heat Exchangers: Part 2, Co-Current Heat Exchangers," ASME Paper No. 55--A-89, 1955.

11.: Kraus, A. D., and D. Q. Kern, "The Effectiveness of Heat Exchangers With One Shell Pass and Even Numbers of Tube Passes," ASME Paper No. 65--HT-18, 1965. 
DISTRIBUTION - RECORD FOR DOE/CS/40010-1

\section{Internal Distribution}

$$
\begin{aligned}
& 1 \text { - } \text { Chicago Patent Group - DOE } \\
& 9800 \text { South Cass } \\
& \text { Argonne, IL } 60439 \\
& 1 \text { - R. L. Blackledge } \text { Idaho Operations : Office - DOE } \\
& \text { Idaho Falls, ID } 83401 \\
& 1 \text { - H. P. Pearson } \text { Information Processing - EG\&G } \\
& 15 \text { - Special Internal }
\end{aligned}
$$

\section{External D1stribution}

$$
\begin{aligned}
& 254 \text { - UC-95f - Energy Conservation--Industry } \\
& 50 \text { - Special External }
\end{aligned}
$$

Total Copies Printed: 322 